\title{
TD 225
}

C43

A 48

20188

Copy 1 


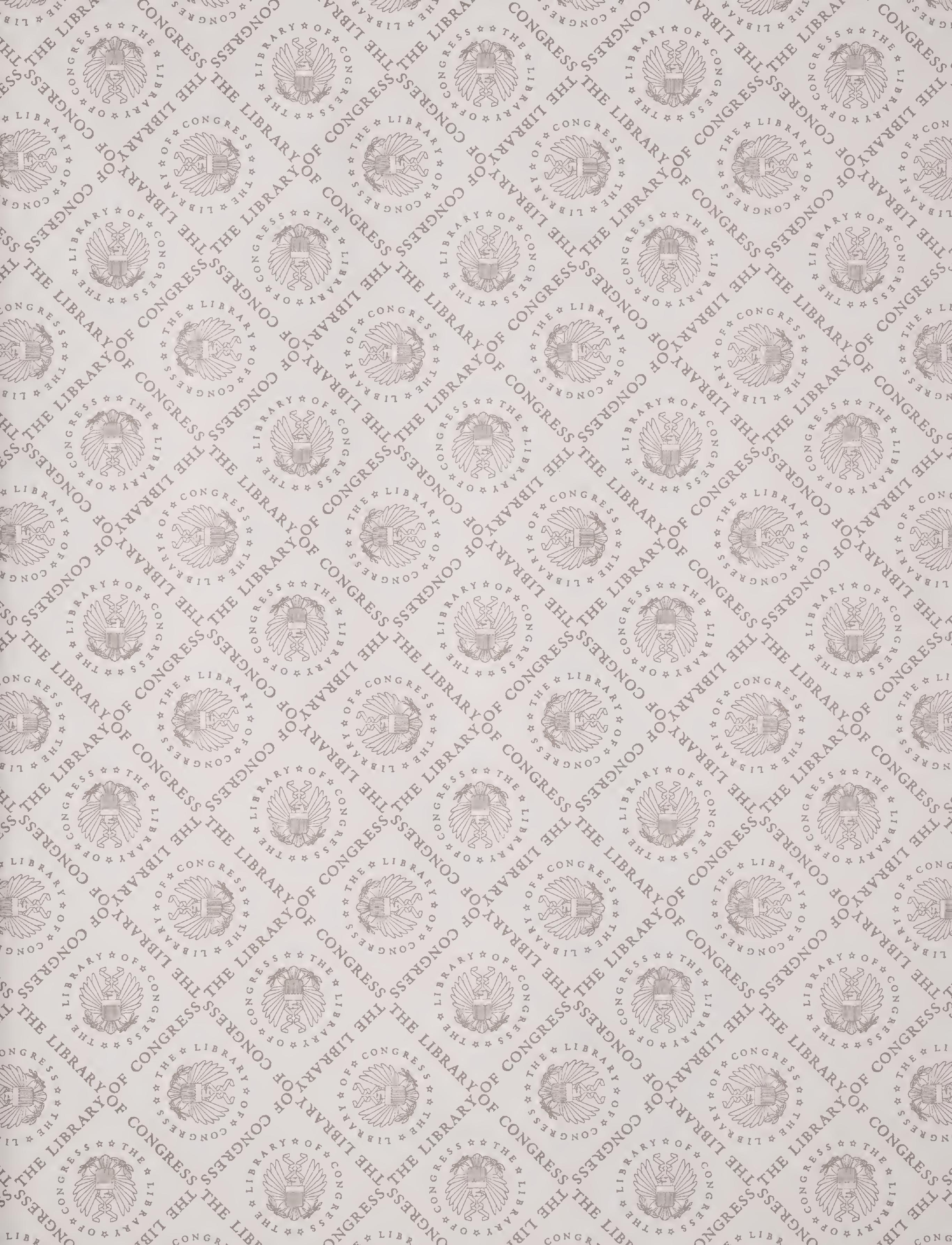



COMAR 26.08.02.03-3

TD 225

. $\mathrm{C43}$

A48

2008

Copy 1

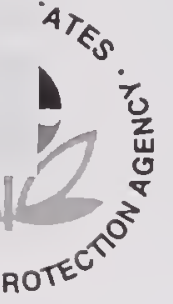

Region III

Chesapeake Bay

nyerlicy
Protection

Program Office
Region III

EPA 903-R-08-001

CBP/TRS 290-08

September 2008

In coordination with the Office of Water/Office of Science and Technology, Washington, D.C., and the states of Delaware, Maryland, New York, Pennsylvania, Virginia and West Virginia and the District of Columbia

Ambient Water Quality Criteria for Dissolved Oxygen, Water Clarity and Chlorophyll a for the Chesapeake Bay and Its Tidal Tributaries

2008 Technical Support for Criteria Assessment Protocols Addendum

September 2008 



\section{Ambient Water Quality Criteria for Dissolved Oxygen, Water Clarity and Chlorophyll a for the Chesapeake Bay and Its Tidal Tributaries: 2008 Technical Support for Criteria Assessment Protocols Addendum}

September 2008

U.S. Environmental Protection Agency

Region III

Chesapeake Bay Program Office

Annapolis, Maryland

and

Region III

Water Protection Division

Philadelphia, Pennsylvania

in coordination with

Office of Water

Office of Science and Technology

Washington, D.C.

and

the states of

Delaware, Maryland, New York,

Pennsylvania, Virginia, and

West Virginia and the District of Columbia 
Library of Congress

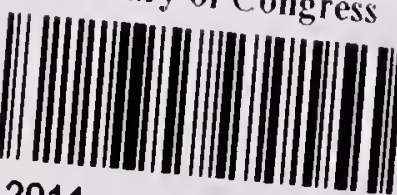

2011

451314

Bib 17091283 


\section{Contents}

Acknowledgments $\ldots \ldots \ldots \ldots \ldots \ldots \ldots \ldots \ldots \ldots \ldots \ldots$

I. Introduction $\ldots \ldots \ldots \ldots \ldots \ldots \ldots \ldots \ldots \ldots \ldots \ldots \ldots \ldots$

Literature Cited $\ldots \ldots \ldots \ldots \ldots \ldots \ldots \ldots \ldots \ldots \ldots \ldots \ldots \ldots$

II. 2008 92-Segment Scheme for the Chesapeake Bay Water Quality Criteria ......................... 5

Background . . . . . . . . . . . . . . . 5

Chesapeake Bay Program Segmentation Schemes ... . . . . . . . 5

2008 Chesapeake Bay and Tidal Tributaries 92-Segment Scheme . . . . 6

Unresolved Boundary for District of Columbia Upper Potomac River . 12

Literature Cited . . . . . . . . . . . . . . . . . . . 12

III. Refinements to Procedures for Assessing Chesapeake Bay

Dissolved Oxygen Criteria ...................... 13

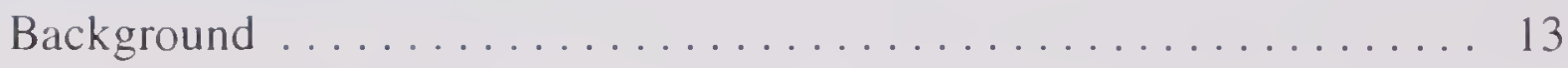

Dissolved Oxygen Criteria Assessment: Stations and Accepted Data . . 14

Pycnocline Definition and Boundaries ................ 15

Revising Designated Use Boundaries with Enhanced Pycnocline

Definition Procedure . . . . . . . . . . . . . . . . . . . 15

Calculation of Upper and Lower Pycnoclines for Dissolved

Oxygen Designated Use Criteria Assessment ............ 15

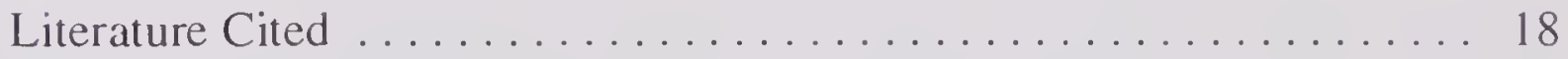

IV. Refinements to Procedures for Assessing Chesapeake Bay Water Clarity and SAV Criteria ... . . . . . . . . . . . . . . . 19

Background ............................ 19

Revision of the Water Clarity Acres Assessment Methodology .... . . 20

Clarification of Water Clarity Assessment Procedures .......... 21

Statistical Model Revision ...................... 21

Converting Turbidity to $K_{d}$ for Calculation of Water Clarity Acres . . 21

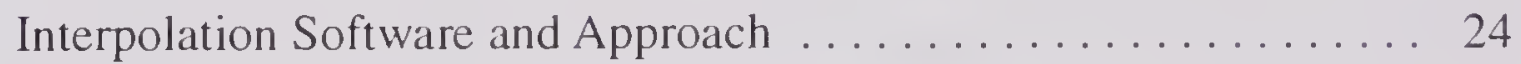

Literature Cited ........................... 24 
V. Chlorophyll a Criteria Assessment Procedures ............ 27

Background ............................. 27

Approach and Protocol Application with Examples . . . . . . . . . . . 29

Types of Output ........................ 30

Future Directions . . . . . . . . . . . . . . . . 32

Literature Cited ............................. 33

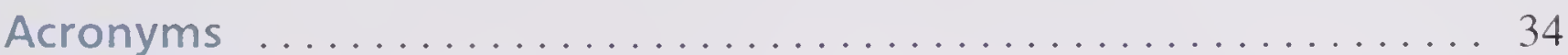

\section{Appendices}

A. Procedure for Assessing Dissolved Oxygen Criteria Attainment: 30-day Criterion, Including Plotting a Bioreference Curve . . . . . . . 35

B. Stations Involved in the 2004-2006 303d Listing Assessment for 2008 . . . 39

C. A Comparison of Methods for Estimating $K_{d} \ldots \ldots \ldots \ldots \ldots 4$

D. Derivation of $K_{d}$ Regressions: DATAFLOW Report on the Lumping vs. Splitting of Regions for MDDNR DATAFLOW $\mathrm{K}_{\mathrm{d}}$ vs. Turbidity Regressions and Calibrations ....................... 47

E. Chesapeake Bay Water Clarity Assessment Framework . . . . . . . . . . . . 59

F. Chesapeake Bay Clarity Criteria Attainment Results .......... 66

G. Chlorophyll $a$ Assessment Protocol $\ldots \ldots \ldots \ldots \ldots \ldots \ldots \ldots$ 


\section{Acknowledgments}

This fifth addendum to the EPA April 2003 publication of Ambient Water Quality Criteria for Dissolved Oxygen, Water Clarity, and Chlorophyll a for Chesapeake Bay and its Tidal Tributaries (Regional Criteria Guidance) was developed and documented through the collaborative efforts of the members of the Chesapeake Bay Program's (CBP) Criteria Assessment Protocols Workgroup and Water Quality Steering Committee.

\section{PRINCIPAL AND CONTRIBUTING AUTHORS}

The document resulted from the collaborative expertise and talents of Chesapeake Bay Program's state agency, federal agency and academic institutional partners. The following are principal and contributing authors of this addendum: Peter Tango, U.S. Geological Survey/Chesapeake Bay Program Office; Jeni Keisman, University of Maryland Center for Environmental Science/Chesapeake Bay Program Office; Richard Batiuk, U.S. EPA Region III Chesapeake Bay Program Office, Mark Trice, Maryland Department of Natural Resources; Frederick Hoffman, Virginia Department of Environmental Quality; Ken Moore, Virginia Institute of Marine Science; David Parrish, Virginia Institute of Marine Science; Tish Robertson, Virginia Department of Environmental Quality; Elgin Perry, Statistics Consultant; Gary Shenk, U.S. EPA Region III Chesapeake Bay Program Office.

\section{CRITERIA ASSESSMENT PROTOCOL WORKGROUP}

Peter Tango, Chair, U.S. Geological Survey; Cheryl Atkinson, United States Environmental Protection Agency; Harry Augustine, Virginia Department of Environmental Quality; Mark Barath, United States Environmental Protection Agency; Tom Barron, Pennsylvania Department of Environmental Protection; Richard Batiuk, United States Environmental Protection Agency; Stephen Cioccia, Virginia Department of Environmental Quality; Elleanor Daub, Virginia Department of Environmental Quality; Thomas Gardner, United States Environmental Protection Agency; Sherm Garrison, Maryland Department of Natural Resources; Darryl Glover, Virginia Department of Environmental Quality; John Hill, Maryland Department of the Environment; Rick Hoffman, Virginia Department of Environmental Quality; Larry Merrill, United States Environmental Protection Agency; Bruce Michael, Maryland Department of Natural Resources; Ken Moore, Virginia Institute of Marine Science; Shah Nawaz, District Department of the Environment; Roland Owens, Virginia Department of Environmental Quality; Jennifer Palmore, Virginia Department of Environmental Quality; Tom Parham, Maryland Department of Natural 
Resources; Elgin Perry, Statistics Consultant; Charles Poukish, Maryland Department of the Environment; Tish Robertson, Virginia Department of Environmental Quality; Matt Rowe, Maryland Department of the Environment; John Schneider, Delaware Department of Natural Resources and Environmental Control; Susan Sciratta, United States Environmental Protection Agency; Gary Shenk, United States Environmental Protection Agency; Donald Smith, Virginia Department of Environmental Quality; Scott Stoner, New York State Department of Environmental Conservation; Matt Stover, Maryland Department of the Environment; Bryant Thomas, Virginia Department of Environmental Quality; Mark Trice, Maryland Department of Natural Resources; Howard Weinberg, University of Maryland Center for Environmental Science; David Wolanski, Delaware Department of Natural Resources and Environmental Control.

\section{WATER QUALITY STEERING COMMITTEE}

Diana Esher, Chair, United States Environmental Protection Agency; Richard Batiuk, United States Environmental Protection Agency; Sheila Besse, District of Columbia Department of the Environment; William Brannon, West Virginia Department of Environmental Protection Division of Water and Waste Management; Patricia Buckley, Pennsylvania Department of Environmental Protection; Katherine BuntingHowarth, Delaware Department of Natural Resources and Environmental Control; Monir Chowdhury, District Department of the Environment; Ron Entringer, New York Department of Environmental Conservation; Richard Eskin, Maryland Department of the Environment; Carlton Haywood, Interstate Commission on the Potomac River Basin; David Heicher, Susquehanna River Basin Commission; Ruth Izraeli, United States Environmental Protection Agency; James Keating, United States Environmental Protection Agency; Teresa Koon, West Virginia Department of Environmental Protection; Robert Koroncai, United States Environmental Protection Agency; Bruce Michael, Maryland Department of Natural Resources; Matt Monroe, West Virginia Department of Agriculture; Kenn Pattison, Pennsylvania Department of Environmental Protection; Russ Perkinson, Virginia Department of Conservation and Recreation; Alan Pollock, Virginia Department of Environmental Quality; John Schneider, Delaware Department of Natural Resources and Environmental Control; Ann Swanson, Chesapeake Bay Commission; Robert Yowell, Pennsylvania Department of Environmental Protection.

The individual and collective contributions from members of the Chesapeake Bay Program Office are also acknowledged: Holly Davis, University of Maryland Center for Environmental Science, Howard Weinberg, University of Maryland Center for Environmental Science/Chesapeake Bay Program Office; John Wolf, National Park Service, Jacob Goodwin, Chesapeake Research Consortium/Chesapeake Bay Program Office; Jamie McNees, Chesapeake Research Consortium/Chesapeake Bay Program Office. 


\section{chapter}

\section{Introduction}

Since the signing of the multijurisdicational Chesapeake 2000 agreement, the U.S. Environmental Protection Agency (EPA), in cooperation with its six watershed State partners and the District of Columbia, has developed a series of water quality criteria guidance documents in accordance with Section 117b of the Clean Water Act. Chesapeake Bay regional water quality criteria were developed and adopted into state water quality standards regulations protective of living resources and their habitats. Five aquatic life tidal-water designated uses were defined by the partners (U.S. EPA 2003a) apportioning the Chesapeake Bay and its tidal tributaries into appropriate habitats:

- Migratory fish spawning and nursery habitat;

- Open water fish and shellfish habitat;

- Deep-water seasonal fish and shellfish habitat;

- Deep-channel seasonal refuge habitat; and

- Shallow-water Bay grass habitat

Ambient Water Quality Criteria for Dissolved Oxygen, Water Clarity and Chlorophyll a for the Chesapeake Bay and Its Tidal Tributaries (Regional Criteria Guidance) April 2003 has been the foundation document defining Chesapeake Bay water quality criteria and recommended implementation procedures for monitoring and assessment (U.S. EPA 2003a). The Technical Support Document for Identification of Chesapeake Bay Designated Uses and Attainability October 2003 defined the five tidal water designated uses to be protected through the published Bay water quality criteria (U.S. EPA 2003b). Six addendum documents have been published since April 2003 addressing detailed issues involving further delineation of tidal water designated uses (U.S. EPA 2004a), Chesapeake Bay Program analytical segmentation schemes (U.S. EPA 2004c, 2005), detailed criteria attainment and assessment procedures, (U.S. EPA 2004b, 2007a), and Chesapeake Bay numerical chlorophyll a criteria (2007b).

The detailed procedures are assessing attainment of the Chesapeake Bay water quality criteria advanced through the collective EPA, States and District of Columbia partner efforts to develop and apply procedures that incorporate, at the most advanced state, magnitude, frequency, duration, space and time considerations with 
biologically-based reference conditions and cumulative frequency distributions. As a rule, the best test of any new method or procedure is putting it to work with stakeholder involvement. Through the work of its Criteria Assessment Protocols Workgroup, the Chesapeake Bay Program has an established forum for resolving details of baywide criteria assessment procedure development and implementation. This addendum document provides previously undocumented features of the present procedures and refinements and clarifications to the previously published Chesapeake Bay water quality criteria assessment procedures.

Chapter 2 documents the most recent Chesapeake Bay 92-segment scheme used for criteria assessment.

Chapter 3 documents refinements and additions to the procedures for assessing the previously published Chesapeake Bay dissolved oxygen criteria.

Chapter 4 documents refinements and additions to the procedures for assessing the previously published Chesapeake Bay water clarity and SAV criteria and determining attainment of the shallow-water designated use.

Chapter 5 documents refinements and additions to the procedures for assessing the previously published Chesapeake Bay chlorophyll $a$ criteria.

Appendices to the chapters include more detailed documentation on derivation of the criteria assessment procedure elements and step-by-step through procedures for assessing criteria.

This document represents the fifth formal addendum to the 2003 Chesapeake Bay water quality criteria document; as such readers should regard the sections in this document as new or replacement chapters and appendices to the original published report. The criteria assessment procedures published in this addendum also replace and otherwise supersede similar criteria assessment procedures originally published in the 2003 Regional Criteria Guidance and the 2004 and 2007 addenda (U.S. EPA 2003a, 2004a, 2007a, b). Publication of future addendums by EPA on behalf of the Chesapeake Bay Program watershed jurisdictional partners is likely as continued scientific research and management applications reveal new insights and knowledge that should be incorporated into revisions of state water quality standards regulations in upcoming triennial reviews.

\section{LITERATURE CITED}

U.S. Environmental Protection Agency. 2003a. Ambient Water Quality Criteria for Dissolved Oxygen. Water Clarity and Chlorophyll a for the Chesapeake Bay and Its Tidal Tributaries (Regional Criteria Guidance) April 2003. EPA 903-R-03-002. Region III Chesapeake Bay Program Office, Annapolis, MD.

U.S. Environmental Protection Agency. 2003b. Technical Support Document for Identification of Chesapeake Bay Designated Uses and Attainability. October 2003. Region III Chesapeake Bay Program Office. EPA 903-R-03-004. Annapolis, MD. 
U.S. Environmental Protection Agency. 2004a. Ambient Water Quality Criteria for Dissolved Oxygen, Water Clarity and Chlorophyll a for the Chesapeake Bay and Its Tidal Tributaries 2004 Addendum. EPA 903-R-04-005. Region III Chesapeake Bay Program Office, Annapolis, MD.

U.S. Environmental Protection Agency. 2004b. Technical Support Document for Identification of Chesapeake Bay Designated Uses and Attainability - 2004 Addendum. October 2004. Region III Chesapeake Bay Program Office. EPA 903-R-04-006. Annapolis, MD.

U.S. Environmental Protection Agency. 2004c. Chesapeake Bay Program Analytical Segmentation Scheme: Revisions, Decisions and Rationales 1983-2003. October 2004. Region III Chesapeake Bay Program Office, Annapolis, MD. EPA 903-R-04-008.

U.S. Environmental Protection Agency. 2005. Chesapeake Bay Program Analytical Segmentation Scheme: Revisions, Decisions and Rationales 1983-2003. 2005 Addendum. December 2005. Region III Chesapeake Bay Program Office, Annapolis, MD. EPA 903-R-05-004.

U.S. Environmental Protection Agency. 2007a. Ambient Water Quality Criteria for Dissolved Oxygen, Water Clarity and Chlorophyll a for the Chesapeake Bay and Its Tidal Tributaries 2007 Addendum. July 2007. EPA 903-R-07-003. Region III Chesapeake Bay Program Office. Annapolis. MD.

U.S. Environmental Protection Agency. 2007b. Ambient Water Quality Criteria for Dissolved Oxygen, Water Clarity and Chlorophyll a for the Chesapeake Bay and Its Tidal Tributaries -Chlorophyll a Addendum. October 2007. EPA 903-R-07-005. Region III Chesapeake Bay Program Office, Annapolis, MD. 



\section{chapter}

\section{92-Segment Scheme for the Chesapeake Bay Water Quality Criteria}

\section{BACKGROUND}

For 25 years, the Chesapeake Bay Program partners have used various versions of a basic segmentation scheme to organize the collection, analysis and presentation of environmental data. The Chesapeake Bay Program Segmentation Scheme: Revisions, decisions and rationales provided documentation on the spatial segmentation scheme of the Chesapeake Bay and its tidal tributaries and the later revisions and changes over the last 25 years (U.S. EPA 2004b, 2005). This chapter provides concise information on the historical 1983, 1997, 2003 segmentation schemes and illustrates the recommended 2008 92-segment scheme for assessing Chesapeake Bay water quality criteria.

\section{CHESAPEAKE BAY PROGRAM SEGMENTATION SCHEMES}

Segmentation is the compartmentalization of the estuary into subunits based on selected criteria. The Chesapeake Bay ecosystem is diverse and complex, and the physical and chemical factors which vary throughout the Bay determine the biological communities and affect the kind and extent of their response to pollution stress. These same factors also influence their response to restoration and remediation. For diagnosing anthropogenic impacts, segmentation is a way to group regions having similar natural characteristics so that differences in water quality and biological communities among similar segments can be identified and their source elucidated. For management purposes, segmentation is a way to group similar regions to define a range of water quality and resource objectives, target implementation of specific actions and monitor responses. It provides a meaningful way to summarize and 
present information in parallel with these objectives and it is a useful geographic pointer for data management.

The Chesapeake Bay Program Segmentation Scheme: Revisions, decisions and rationales 1983-2003 (U.S. EPA 2004b, 2005) contains the following maps and tables used to document changes to the segmentation scheme from 1983 through 2003 as well as provide the jurisdictions with detailed documentation on the geographical delineation of each segment's boundaries:

- Maps for the 1983, 1997 and 2003 segmentation schemes;

- Statistics on the perimeter, surface area and volume of each Chesapeake Bay Program segment;

- Narrative descriptions of each of the coordinates bounding each Chesapeake Bay Program segment; and

- Maps of all the Chesapeake Bay Water Quality Monitoring Program stations displayed by segment by Maryland, Virginia and the District of Columbia.

A concise history of the original 1983 segmentation scheme, and the 1997 and 2003 revised segmentation schemes is published in Chapter 3 of the U.S. EPA (2004a) Technical Support Document for identification of Chesapeake Designated Uses and Attainability, 2004 Addendum. A detailed history of segmentation schemes is provided in the Chesapeake Bay Program Segment Scheme document at http://www.chesapeakebay.net/pubs/segmentscheme.pdf and the summary documents of U.S. EPA 2004b, 2005.

\section{CHESAPEAKE BAY AND TIDAL TRIBUTARIES 92 -SEGMENT SCHEME}

The 92-segment scheme for the Chesapeake Bay and its tidal tributaries used for dissolved oxygen and water clarity assessments in the $2008303 \mathrm{~d} / 305 \mathrm{~b}$ listing efforts of the four Bay tidal jurisdictions is documented here. The 92-segment scheme was derived from: 1) the 2003 published 78-segment scheme with the addition of jurisdictional boundary lines imposed to create 89 segments; then 2) includes only the split segments agreed upon for the tidal James and Potomac rivers. The result of the State partners' decisions on the Chesapeake Bay water quality criteria assessment framework is the 92-segment scheme (Figure II-I), a subset of the 2003 104-segment scheme that defined boundaries of split segments published in U.S. EPA 2004b. Table II- 1 is a complementary reference table that lists the 92 segments definitions according to their application across the 25 year history of Chesapeake Bay segment schemes. 


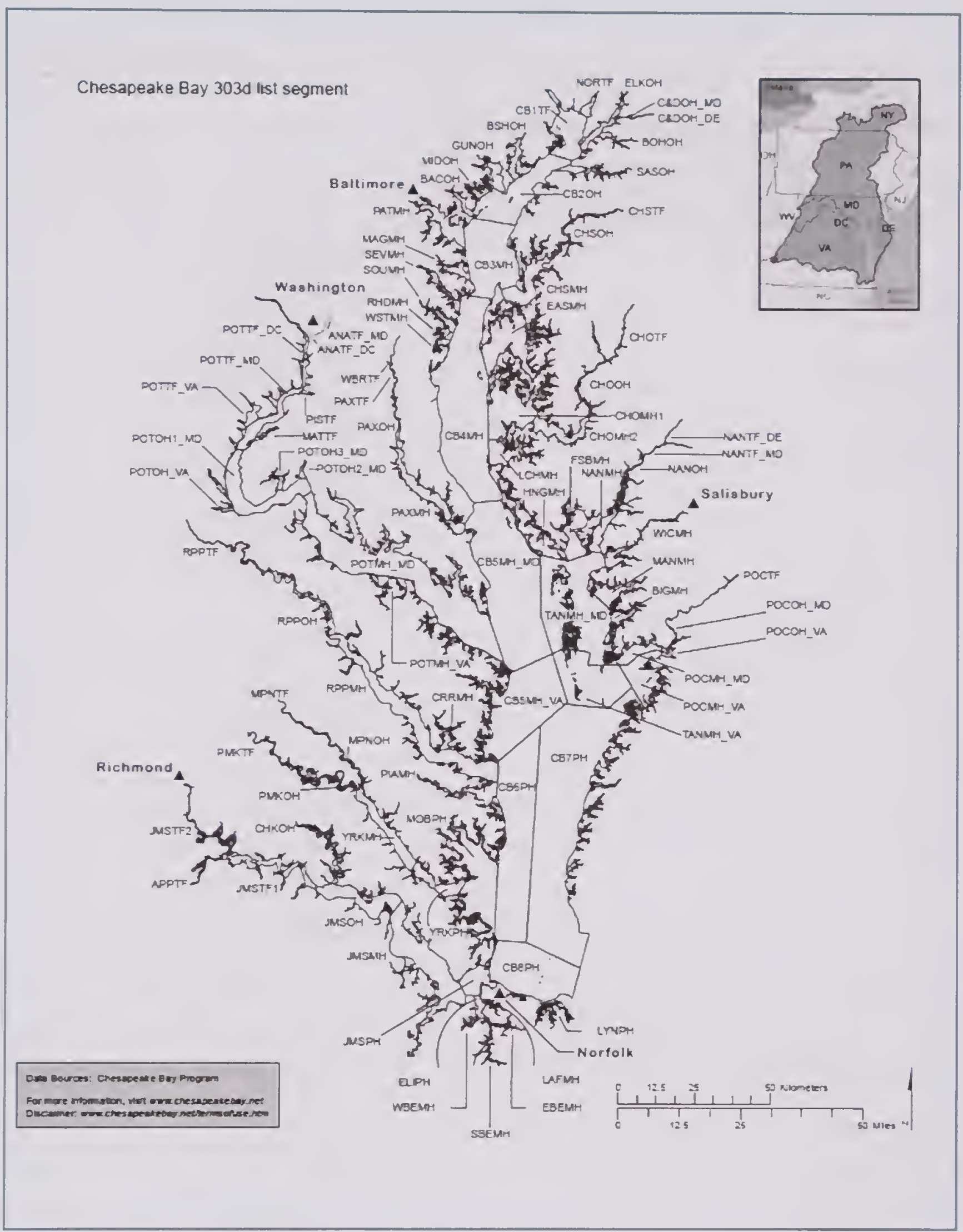

Figure II-1. 2008 Chesapeake Bay 92-segment scheme. 
Table II-1. Segment acronyms and their historical context to 1983, 1997, 2003 and 2008 Chesapeake Bay segmentation schemes ${ }^{1}$.

\begin{tabular}{|c|c|c|c|c|c|}
\hline \multirow{2}{*}{$\begin{array}{l}\text { Chesapeake } \\
\text { Bay Program } \\
\text { Segment-Name } \\
\text { Nomenclature }^{1}\end{array}$} & \multicolumn{4}{|c|}{$\begin{array}{c}\text { Chesapeake Bay Program Segment Scheme Membership } \\
\qquad(\mathrm{Y}=\text { Yes, N=No) }\end{array}$} & \multirow{2}{*}{ Tidal Water Body } \\
\hline & $\begin{array}{c}1985 \\
78 \text { segments }\end{array}$ & $\begin{array}{c}1997 \\
89 \text { segments }\end{array}$ & $\begin{array}{c}2003 \\
104 \text { segments }\end{array}$ & $\begin{array}{l}2008 \\
92 \text { segments }\end{array}$ & \\
\hline ANATF & $\mathrm{Y}$ & $\mathrm{N}$ & $\mathrm{N}$ & $\mathrm{N}$ & Anacostia River \\
\hline ANATF_DC & $\mathrm{N}$ & Y & Y & $\mathrm{Y}$ & Anacostia River, DC \\
\hline ANATF_MD & $\mathrm{N}$ & Y & Y & Y & Anacostia River, MD \\
\hline APPTF & Y & Y & Y & $\mathrm{Y}$ & Appomattox River \\
\hline $\mathrm{BACOH}$ & Y & Y & $\mathrm{Y}$ & $\mathrm{Y}$ & Back River \\
\hline BIGMH & Y & Y & $\mathrm{N}$ & $\mathrm{Y}$ & Big Annemessex River \\
\hline BIGMHI & $\mathrm{N}$ & $\mathrm{N}$ & $\mathrm{Y}$ & $\mathrm{N}$ & Big Annemessex River, Lower \\
\hline BIGMH2 & $\mathrm{N}$ & $\mathrm{N}$ & $\mathrm{Y}$ & $\mathrm{N}$ & Big Annemessex River, Upper \\
\hline $\mathrm{BOHOH}$ & Y & Y & $\mathrm{Y}$ & $\mathrm{Y}$ & Bohemia River \\
\hline $\mathrm{BSHOH}$ & Y & $\mathrm{Y}$ & Y & $\mathrm{Y}$ & Bush River \\
\hline $\mathrm{C} \& \mathrm{DOH}$ & $\mathrm{Y}$ & $\mathrm{N}$ & $\mathrm{N}$ & $\mathrm{N}$ & C\&D Canal \\
\hline C\&DOH_DE & $\mathrm{N}$ & $\mathrm{Y}$ & $\mathrm{Y}$ & $\mathrm{Y}$ & C\&D Canal. DE \\
\hline C\&DOH_MD & $\mathrm{N}$ & $\mathrm{Y}$ & $\mathrm{Y}$ & $\mathrm{Y}$ & C\&D Canal, MD \\
\hline CBITF & $\mathrm{Y}$ & $\mathrm{Y}$ & $\mathrm{N}$ & $\mathrm{Y}$ & Northern Chesapeake Bay \\
\hline CBITFI & $\mathrm{N}$ & $\mathrm{N}$ & $\mathrm{Y}$ & $\mathrm{N}$ & $\begin{array}{l}\text { Northern Chesapeake Bay - } \\
\text { Turkey Pt South }\end{array}$ \\
\hline CB1TF2 & N & N & Y & $\mathrm{N}$ & $\begin{array}{l}\text { Northern Chesapeake Bay - } \\
\text { Susquehanna River and Flats }\end{array}$ \\
\hline $\mathrm{CB} 2 \mathrm{OH}$ & Y & $\mathrm{Y}$ & $\mathrm{Y}$ & $\mathrm{Y}$ & Upper Chesapeake Bay \\
\hline CB3MH & $\mathrm{Y}$ & $\mathrm{Y}$ & $\mathrm{Y}$ & $\mathrm{Y}$ & Upper Central Chesapeake Bay \\
\hline $\mathrm{CB} 4 \mathrm{MH}$ & Y & $\mathrm{Y}$ & $\mathrm{Y}$ & $\mathrm{Y}$ & Middle Central Chesapeake Bay \\
\hline CB5MH & $\mathrm{Y}$ & $\mathrm{N}$ & $\mathrm{N}$ & $\mathrm{N}$ & Lower Central Chesapeake Bay \\
\hline CB5MH_MD & $\mathrm{N}$ & Y & Y & Y & $\begin{array}{l}\text { Lower Central Chesapeake Bay. } \\
\text { MD }\end{array}$ \\
\hline CB5MH_VA & $\mathrm{N}$ & Y & Y & Y & $\begin{array}{l}\text { Lower Central Chesapeake Bay, } \\
\text { VA }\end{array}$ \\
\hline $\mathrm{CB} 6 \mathrm{PH}$ & $\mathrm{Y}$ & $\mathrm{Y}$ & $\mathrm{Y}$ & $\mathrm{Y}$ & Western Lower Chesapeake Bay \\
\hline $\mathrm{CB} 7 \mathrm{PH}$ & Y & $\mathrm{Y}$ & $\mathrm{Y}$ & $\mathrm{Y}$ & Eastern Lower Chesapeake Bay \\
\hline $\mathrm{CB} 8 \mathrm{PH}$ & $\mathrm{Y}$ & $\mathrm{Y}$ & $\mathrm{Y}$ & $\mathrm{Y}$ & Mouth of Chesapeake Bay \\
\hline $\mathrm{CHKOH}$ & $\mathrm{Y}$ & $\mathrm{Y}$ & $\mathrm{Y}$ & $\mathrm{Y}$ & Chickahominy River \\
\hline СНOMH 1 & Y & Y & Y & Y & Lower Choptank River \\
\hline
\end{tabular}

${ }^{1}$ Note: Group acronyms are a combination of river and salinity zone membership. An example is BSHOH where BSH=Bush River and $\mathrm{OH}=$ Oligohaline zone. Salinity zones are $\mathrm{TF}=$ Tidal Fresh, $\mathrm{OH}=$ Oligohaline, $\mathrm{MH}=$ Mesohaline, $\mathrm{PH}=$ Polyhaline. 
Table $11-1$. (continued).

\begin{tabular}{|c|c|c|c|c|c|}
\hline \multirow{2}{*}{$\begin{array}{l}\text { Chesapeake } \\
\text { Bay Program } \\
\text { Segment-Name } \\
\text { Nomenclature }^{1}\end{array}$} & \multicolumn{4}{|c|}{$\begin{array}{l}\text { Chesapeake Bay Program Segment Scheme Membership } \\
\qquad\left(\mathrm{Y}=\mathrm{Yes}, \mathrm{N}=\mathrm{N}_{0}\right)\end{array}$} & \multirow[b]{2}{*}{ Tidal Water Body } \\
\hline & $\begin{array}{l}1985 \\
78 \text { segments }\end{array}$ & $\begin{array}{c}1997 \\
89 \text { segments }\end{array}$ & $\begin{array}{l}2003 \\
104 \text { segments }\end{array}$ & $\begin{array}{c}2008 \\
92 \text { segments }\end{array}$ & \\
\hline $\mathrm{CHOMH} 2$ & $\mathrm{Y}$ & $\mathrm{Y}$ & $\mathrm{Y}$ & $\mathrm{Y}$ & Mouth of Choptank River \\
\hline $\mathrm{CHOOH}$ & $\mathrm{Y}$ & $\mathrm{Y}$ & $\mathrm{Y}$ & $\mathrm{Y}$ & Middle Choptank River \\
\hline CHOTF & $\mathrm{Y}$ & Y & $\mathrm{Y}$ & $\mathrm{Y}$ & Upper Choptank River \\
\hline CHSMH & $\mathrm{Y}$ & Y & $\mathrm{Y}$ & $\mathrm{Y}$ & Lower Chester River \\
\hline $\mathrm{CHSOH}$ & $\mathrm{Y}$ & $\mathrm{Y}$ & $\mathrm{Y}$ & $\mathrm{Y}$ & Middle Chester River \\
\hline CHSTF & $\mathrm{Y}$ & $\mathrm{Y}$ & $\mathrm{Y}$ & $\mathrm{Y}$ & Upper Chester River \\
\hline CRRMH & $\mathrm{Y}$ & $\mathrm{Y}$ & $\mathrm{Y}$ & $\mathrm{Y}$ & Corrotoman River \\
\hline EASMH & $\mathrm{Y}$ & Y & $\mathrm{Y}$ & $\mathrm{Y}$ & Eastern Bay \\
\hline EBEMH & $\mathrm{Y}$ & Y & $\mathrm{Y}$ & $\mathrm{Y}$ & Eastern Branch Elizabeth River \\
\hline ELIPH & $\mathrm{Y}$ & $\mathrm{Y}$ & $\mathrm{Y}$ & $\mathrm{Y}$ & Mouth-mid Elizabeth River \\
\hline ELKOH & $\mathrm{Y}$ & $\mathrm{Y}$ & $\mathrm{N}$ & $\mathrm{Y}$ & Elk River \\
\hline ELKOHI & $\mathrm{N}$ & $\mathrm{N}$ & $\mathrm{Y}$ & $\mathrm{N}$ & Elk River. Upper \\
\hline ELKOH2 & $\mathrm{N}$ & $\mathrm{N}$ & $\mathrm{Y}$ & $\mathrm{N}$ & Elk River. Lower \\
\hline FSBMH & $\mathrm{Y}$ & $\mathrm{Y}$ & $\mathrm{Y}$ & $\mathrm{Y}$ & Fishing Bay \\
\hline GUNOH & $\mathrm{Y}$ & $\mathrm{Y}$ & $\mathrm{N}$ & $\mathrm{Y}$ & Gunpowder River \\
\hline GUNOHI & $\mathrm{N}$ & $\mathrm{N}$ & Y & $\mathrm{N}$ & Gunpowder River, Upper \\
\hline GUNOH2 & $\mathrm{N}$ & $\mathrm{N}$ & $\mathrm{Y}$ & $\mathrm{N}$ & Gunpowder River, Lower \\
\hline HNGMH & $\mathrm{Y}$ & $\mathrm{Y}$ & $\mathrm{Y}$ & $\mathrm{Y}$ & Honga River \\
\hline JMSMH & $\mathrm{Y}$ & $\mathrm{Y}$ & $\mathrm{Y}$ & $\mathrm{Y}$ & Lower James River \\
\hline $\mathrm{JMSOH}$ & $\mathrm{Y}$ & $\mathrm{Y}$ & $\mathrm{Y}$ & $\mathrm{Y}$ & Middle James River \\
\hline JMSPH & $\mathrm{Y}$ & $\mathrm{Y}$ & $\mathrm{Y}$ & $\mathrm{Y}$ & Mouth of James River \\
\hline JMSTF & $\mathrm{Y}$ & $\mathrm{Y}$ & $\mathrm{N}$ & $\mathrm{N}$ & Upper James River \\
\hline JMSTF1 & $\mathrm{N}$ & $\mathrm{N}$ & $\mathrm{Y}$ & $\mathrm{Y}$ & Upper James River - Lower \\
\hline JMSTF2 & $\mathrm{N}$ & $\mathrm{N}$ & $\mathrm{Y}$ & $\mathrm{Y}$ & Upper James River - Upper \\
\hline LAFMH & $\mathrm{Y}$ & $\mathrm{Y}$ & $\mathrm{Y}$ & $\mathrm{Y}$ & Lafayette River \\
\hline LCHMH & $\mathrm{Y}$ & $\mathrm{Y}$ & Y & $\mathrm{Y}$ & Little Choptank River \\
\hline LYNPH & $\mathrm{Y}$ & $\mathrm{Y}$ & Y & $\mathrm{Y}$ & Lynnhaven River \\
\hline MAGMH & Y & $\mathrm{Y}$ & Y & $\mathrm{Y}$ & Magothy River \\
\hline MANMH & $\mathrm{Y}$ & $\mathrm{Y}$ & $\mathrm{N}$ & $\mathrm{Y}$ & Manokin River \\
\hline MANMHI & $\mathrm{N}$ & $\mathrm{N}$ & $\mathrm{Y}$ & $\mathrm{N}$ & Manokin River, Lower \\
\hline MANMH2 & $\mathrm{N}$ & $\mathrm{N}$ & $\mathrm{Y}$ & $\mathrm{N}$ & Manokin River, Upper \\
\hline MATTF & $\mathrm{Y}$ & $\mathrm{Y}$ & $\mathrm{Y}$ & $\mathrm{Y}$ & Mattawoman Creek \\
\hline
\end{tabular}


Table 11-1. (continued).

\begin{tabular}{|c|c|c|c|c|c|}
\hline \multirow{2}{*}{$\begin{array}{l}\text { Chesapeake } \\
\text { Bay Program } \\
\text { Segment-Name } \\
\text { Nomenclature }\end{array}$} & \multicolumn{4}{|c|}{$\begin{array}{l}\text { Chesapeake Bay Program Segment Scheme Membership } \\
\qquad(\mathrm{Y}=\mathrm{Yes}, \mathrm{N}=\text { No) }\end{array}$} & \multirow{2}{*}{ Tidal Water Body } \\
\hline & $\begin{array}{l}1985 \\
78 \text { segments }\end{array}$ & $\begin{array}{l}1997 \\
89 \text { segments }\end{array}$ & $\begin{array}{l}2003 \\
104 \text { segments }\end{array}$ & $\begin{array}{l}2008 \\
92 \text { segments }\end{array}$ & \\
\hline MIDOH & $\mathrm{Y}$ & $\mathrm{Y}$ & Y & $\mathrm{Y}$ & Middle River \\
\hline МOBPH & Y & Y & Y & Y & Mobjack Bay \\
\hline MPNOH & Y & Y & Y & Y & Lower Mattaponi River \\
\hline MPNTF & $\mathrm{Y}$ & $\mathrm{Y}$ & $\mathrm{Y}$ & $\mathrm{Y}$ & Upper Mattaponi River \\
\hline NANMH & Y & Y & Y & Y & Lower Nanticoke River \\
\hline $\mathrm{NANOH}$ & $\mathrm{Y}$ & $\mathrm{Y}$ & Y & $\mathrm{Y}$ & Middle Nanticoke River \\
\hline NANTF & $\mathrm{Y}$ & $\mathrm{N}$ & $\mathrm{N}$ & $\mathrm{N}$ & Upper Nanticoke River \\
\hline NANTF_DE & $\mathrm{N}$ & $\mathrm{Y}$ & $\mathrm{Y}$ & $\mathrm{Y}$ & Upper Nanticoke River, DE \\
\hline NANTF_MD & $\mathrm{N}$ & $\mathrm{Y}$ & $\mathrm{Y}$ & $\mathrm{Y}$ & Upper Nanticoke River, MD \\
\hline NORTF & $\mathrm{Y}$ & $\mathrm{Y}$ & $\mathrm{Y}$ & $\mathrm{Y}$ & Northeast River \\
\hline PATMH & $\mathrm{Y}$ & $\mathrm{Y}$ & Y & $\mathrm{Y}$ & Patapsco River \\
\hline PAXMH & $\mathrm{Y}$ & Y & $N$ & $\mathrm{Y}$ & Lower Patuxent River \\
\hline PAXMHI & $\mathrm{N}$ & $\mathrm{N}$ & Y & $\mathrm{N}$ & Lower Patuxent River, Lower \\
\hline $\mathrm{PAXMH} 2$ & $\mathrm{~N}$ & $\mathrm{~N}$ & $\mathrm{Y}$ & $\mathrm{N}$ & Lower Patuxent River, Upper \\
\hline PAXMH3 & $\mathrm{N}$ & $\mathrm{N}$ & $\mathrm{Y}$ & $\mathrm{N}$ & Lower Patuxent River, Mill Creek \\
\hline PAXMH4 & $\mathrm{N}$ & $\mathrm{N}$ & Y & $\mathrm{N}$ & $\begin{array}{l}\text { Lower Patuxent River, } \\
\text { Cuckold Creek }\end{array}$ \\
\hline PAXMH5 & $\mathrm{N}$ & $\mathrm{N}$ & $\mathrm{Y}$ & $\mathrm{N}$ & $\begin{array}{l}\text { Lower Patuxent River, } \\
\text { St. Leonard Creek }\end{array}$ \\
\hline PAXMH6 & $\mathrm{N}$ & $\mathrm{N}$ & $\mathrm{Y}$ & $\mathrm{N}$ & Lower Patuxent River, Island Creek \\
\hline $\mathrm{PAXOH}$ & $\mathrm{Y}$ & $\mathrm{Y}$ & $\mathrm{Y}$ & $\mathrm{Y}$ & Middle Patuxent River \\
\hline PAXTF & $\mathrm{Y}$ & $\mathrm{Y}$ & $\mathrm{Y}$ & $\mathrm{Y}$ & Upper Patuxent River \\
\hline PIAMH & $\mathrm{Y}$ & $\mathrm{Y}$ & $\mathrm{Y}$ & Y & Piankatank River \\
\hline PISTF & $\mathrm{Y}$ & $\mathrm{Y}$ & $\mathrm{Y}$ & $\mathrm{Y}$ & Piscataway Creek \\
\hline $\mathrm{PMKOH}$ & $\mathrm{Y}$ & $\mathrm{Y}$ & $\mathrm{Y}$ & $\mathrm{Y}$ & Lower Pamunkey River \\
\hline PMKTF & $\mathrm{Y}$ & $\mathrm{Y}$ & $\mathrm{Y}$ & $\mathrm{Y}$ & Upper Pamunkey River \\
\hline POCMH & $\mathrm{Y}$ & $\mathrm{N}$ & $\mathrm{N}$ & $\mathrm{N}$ & Lower Pocomoke River \\
\hline POCMH_MD & $\mathrm{N}$ & Y & $\mathrm{Y}$ & Y & Lower Pocomoke River, MD \\
\hline POCMH_VA & $\mathrm{N}$ & $\mathrm{Y}$ & Y & $\mathrm{Y}$ & Lower Pocomoke River, VA \\
\hline $\mathrm{POCOH}$ & $\mathrm{Y}$ & $\mathrm{N}$ & $\mathrm{N}$ & $\mathrm{N}$ & Middle Pocomoke River \\
\hline POCOH_MD & $\mathrm{N}$ & $\mathrm{Y}$ & Y & $\mathrm{Y}$ & Middle Pocomoke River, MD \\
\hline POCOH_VA & $\mathrm{N}$ & Y & $\mathrm{Y}$ & Y & Middle Pocomoke River, VA \\
\hline POCTF & $\mathrm{Y}$ & Y & Y & $\mathrm{Y}$ & Upper Pocomoke River \\
\hline POTMH & $\mathrm{Y}$ & $\mathrm{N}$ & $\mathrm{N}$ & $\mathrm{N}$ & Lower Potomac River \\
\hline POTMH_MD & $\mathrm{N}$ & Y & Y & Y & Lower Potomac River, MD \\
\hline
\end{tabular}


Table II-1. (continued).

\begin{tabular}{|c|c|c|c|c|c|}
\hline \multirow{2}{*}{$\begin{array}{l}\text { Chesapeake } \\
\text { Bay Program } \\
\text { Segment-Name } \\
\text { Nomenclature }\end{array}$} & \multicolumn{4}{|c|}{$\begin{array}{l}\text { Chesapeake Bay Program Segment Scheme Membership } \\
\qquad(\mathrm{Y}=\mathrm{Yes}, \mathrm{N}=\mathrm{No})\end{array}$} & \multirow[b]{2}{*}{ Tidal Water Body } \\
\hline & $\begin{array}{l}1985 \\
78 \text { segments }\end{array}$ & $\begin{array}{l}1997 \\
89 \text { segments }\end{array}$ & $\begin{array}{c}2003 \\
104 \text { segments }\end{array}$ & $\begin{array}{c}2008 \\
92 \text { segments }\end{array}$ & \\
\hline POTMH_VA & $\mathrm{N}$ & $\mathrm{Y}$ & Y & Y & Lower Potomac River. VA \\
\hline РОТОН & Y & $N$ & $\mathrm{~N}$ & $\mathrm{~N}$ & Middle Potomac River \\
\hline POTOH_MD & $\mathrm{N}$ & $\mathrm{Y}$ & $\mathrm{N}$ & $N$ & Middle Potomac River. MD \\
\hline POTOH_VA & $\mathrm{N}$ & $\mathrm{Y}$ & $\mathrm{Y}$ & $\mathrm{Y}$ & Middle Potomac River. VA \\
\hline POTOH1_MD & $\mathrm{N}$ & $\mathrm{N}$ & Y & Y & $\begin{array}{l}\text { Middle Potomac River, } \\
\text { MD Mainstem }\end{array}$ \\
\hline POTOH2_MD & $N$ & $\mathrm{~N}$ & Y & Y & $\begin{array}{l}\text { Middle Potomac River. } \\
\text { MD Port Tobacco River }\end{array}$ \\
\hline POTOH3_MD & $N$ & $\mathrm{~N}$ & Y & Y & $\begin{array}{l}\text { Middle Potomac River, } \\
\text { MD Nanjemoy Creek }\end{array}$ \\
\hline POTTF & $\mathrm{Y}$ & $\mathrm{N}$ & $\mathrm{N}$ & $\mathrm{N}$ & Upper Potomac River \\
\hline POTTF_DC & $\mathrm{N}$ & Y & Y & Y & Upper Potomac River, DC \\
\hline POTTF_MD & $\mathrm{N}$ & $\mathrm{Y}$ & Y & $\mathrm{Y}$ & Upper Potomac River. MD \\
\hline POTTF_VA & $\mathrm{N}$ & $\mathrm{Y}$ & $\mathrm{Y}$ & $\mathrm{Y}$ & Upper Potomac River, VA \\
\hline RHDMH & $\mathrm{Y}$ & $\mathrm{Y}$ & Y & $\mathrm{Y}$ & Rhode River \\
\hline RPPMH & $\mathrm{Y}$ & $\mathrm{Y}$ & $\mathrm{Y}$ & $\mathrm{Y}$ & Lower Rappahannock River \\
\hline RPPOH & Y & $\mathrm{Y}$ & Y & $\mathrm{Y}$ & Middle Rappahannock River \\
\hline RPPTF & Y & $\mathrm{Y}$ & $\mathrm{Y}$ & $\mathrm{Y}$ & Upper Rappahannock River \\
\hline $\mathrm{SASOH}$ & Y & Y & $\mathrm{N}$ & $\mathrm{Y}$ & Sassafras River \\
\hline SASOHI & $\mathrm{N}$ & $\mathrm{N}$ & Y & $N$ & Sassafras River. Lower \\
\hline $\mathrm{SASOH} 2$ & $\mathrm{~N}$ & $\mathrm{~N}$ & Y & $\mathrm{N}$ & Sassafras River. Upper \\
\hline SBEMH & Y & Y & Y & Y & Southern Branch Elizabeth River \\
\hline SEVMH & Y & $\mathrm{Y}$ & Y & Y & Severn River \\
\hline SOUMH & $\mathrm{Y}$ & $\mathrm{Y}$ & Y & $\mathrm{Y}$ & South River \\
\hline TANMH & $\mathrm{Y}$ & $\mathrm{N}$ & N & $N$ & Tangier Sound \\
\hline TANMH_MD & $\mathrm{N}$ & Y & $\mathrm{N}$ & $\mathrm{Y}$ & Tangier Sound, MD \\
\hline TANMH_VA & $\mathrm{N}$ & $\mathrm{Y}$ & Y & Y & Tangier Sound. VA \\
\hline TANMH1_MD & $\mathrm{N}$ & $\mathrm{N}$ & Y & $\mathrm{N}$ & Tangier Sound. MD. Main Body \\
\hline TANMH2_MD & $\mathrm{N}$ & $\mathrm{N}$ & Y & $\mathrm{N}$ & $\begin{array}{l}\text { Tangier Sound. MD. Deal Island to } \\
\text { Mouth of Nanticoke River }\end{array}$ \\
\hline WBEMH & $\mathrm{Y}$ & $\mathrm{Y}$ & Y & Y & Western Branch Elizabeth River \\
\hline WBRTF & $\mathrm{Y}$ & Y & Y & Y & Western Branch Patuxent River \\
\hline WICMH & $\mathrm{Y}$ & $\mathrm{Y}$ & Y & $\mathrm{Y}$ & Wicomico River \\
\hline WSTMH & $\mathrm{Y}$ & $\mathrm{Y}$ & $\mathrm{Y}$ & Y & West River \\
\hline YRKMH & $\mathrm{Y}$ & Y & Y & Y & Middle York River \\
\hline YRKPH & $\mathrm{Y}$ & $\mathrm{Y}$ & Y & $\mathrm{Y}$ & Lower York River \\
\hline
\end{tabular}




\section{UNRESOLVED BOUNDARY FOR DISTRICT OF COLUMBIA UPPER POTOMAC RIVER}

This 92-segment scheme is the agreed upon 2008 assessment segmentation. Final programming adjustments for boundary conditions of the jurisdictions were made in autumn 2007. During early winter 2007/8, an unresolved upper boundary location for the District of Columbia segment of the Tidal Fresh Potomac River came to light due to unresolved station classifications (tidal vs. nontidal) to revise the boundary. With assessment calculations underway, it was a nontrivial task to revise the map at this segment boundary which could have affected assessments already completed for the jurisdictions. The result, coupled with data limitations affected Washington District of Columbia in 2008 for a "no attainment assessment" result in their $303 \mathrm{~d} / 305 \mathrm{~b}$ listing. This boundary condition will be resolved for the next triennial review.

\section{LITERATURE CITED}

U.S. Environmental Protection Agency. 2003a. Ambient Water Quality Criteria for Dissolved Oxygen, Water Clarity and Chlorophyll a for the Chesapeake Bay and Its Tidal Tributaries (Regional Criteria Guidance) April 2003. EPA 903-R-03-002. Region III Chesapeake Bay Program Office, Annapolis, MD.

U.S. Environmental Protection Agency. 2003b. Technical Support Document for Identification of Chesapeake Bay Designated Uses and Attainability: October 2003. October 2004. Region III Chesapeake Bay Program Office. EPA 903-R-03-004. Annapolis, MD.

U.S. Environmental Protection Agency. 2004a. Technical Support Document for Identification of Chesapeake Bay Designated Uses and Attainability - 2004 Addendum. October 2004. Region III Chesapeake Bay Program Office. EPA 903-R-04-006. Annapolis, MD.

U.S. Environmental Protection Agency. 2004b. Chesapeake Bay Program Analytical Segmentation Scheme: Revisions, Decisions and Rationales 1983-2003. October 2004. Region III Chesapeake Bay Program Office, Annapolis, MD. EPA 903-R-04-008.

U.S. Environmental Protection Agency. 2005. Chesapeake Bay Program Analytical Segmentation Scheme: Revisions, Decisions and Rationales 1983-2003. 2005 Addendum. December 2005. Region III Chesapeake Bay Program Office, Annapolis, MD. EPA 903-R-05-004. 


\section{chapter iii}

\section{Refinements to Procedures for Assessing Chesapeake Bay Dissolved Oxygen Criteria}

\section{BACKGROUND}

In 2003, the EPA published detailed criteria for dissolved oxygen tailored to different habitats within the Chesapeake Bay and its tidal tributaries (U.S. EPA 2003a). Oxygen is critical to most forms of life in the Bay; it must be available in adequate concentrations to support overall ecosystem health. Minimum concentrations of dissolved oxygen must be present to support the diversity of species and their various life stages requiring protection.

Dissolved oxygen criteria were established for Chesapeake Bay that varied in space (e.g., designated uses) and time (e.g., summer) to provide protection for different species and communities. The criteria were also designed around several durations (e.g., 30-day, 1-day) to reflect the varying oxygen tolerances for different life stages (e.g., larval, juvenile, adult) and effects (e.g., mortality, growth, behavior). Thus, the dissolved oxygen criteria include multiple components. Each component includes a target of dissolved oxygen concentration, the duration over which the concentration is averaged, the space (designated-use area) where the criterion applies, and a time (season, months) when the criterion applies. EPA has published, and the States adopted into their water quality standards regulations, dissolved oxygen criteria protective of migratory spawning, open-water, deep-water, and deep-channel designated-use habitats (U.S. EPA 2003a). These dissolved oxygen criteria include 30-day, 7-day, and 1-day means along with instantaneous minima.

Since the Chesapeake Bay dissolved oxygen criteria were published in 2003, the capability of fully assessing all the dissolved oxygen criteria for all four designated uses over all applicable time periods has progressed, however, some limitations remain. The refined and expanded dissolved oxygen criteria assessment methodologies documented in this chapter replace the methodologies previous published by EPA. Work by EPA and its partners will continue to refine these methodologies to reduce uncertainty further and to increase confidence in the resulting assessments. 
Developing, validating and publishing EPA-recommended methodologies for assessing the full array of Chesapeake Bay dissolved oxygen criteria duration components will also prove critical. In this chapter and its associated appendices, details and clarifications regarding data structure and assessment protocols are provided for completing Chesapeake Bay dissolved oxygen criteria attainment computations.

\section{DISSOLVED OXYGEN ASSESSMENT: STATIONS AND ACCEPTED DATA}

The EPA water quality criteria assessment methodologies adopted by the Chesapeake Bay watershed jurisdictions recommend 3 consecutive years of data to construct the cumulative frequency distribution function to compare with the biological or other recommended reference curve (U.S. EPA 2003a). Step-by-step procedures of the Chesapeake Bay dissolved oxygen criteria attainment assessment methodology are provided for in Appendix A. A dissolved oxygen dataset was developed for a suite of Chesapeake Bay Program monitoring stations, and ancillary monitoring stations (VA), in the tidal waters of the Chesapeake Bay and its tidal tributaries and embayments (Appendix B) stored on-line in the Chesapeake Information Management System (CIMS).

A database table was assembled for dissolved oxygen $(\mu \mathrm{g} / \mathrm{L})$, water temperature $\left({ }^{\circ} \mathrm{C}\right)$ and salinity (ppt) using all tidal Chesapeake Bay Program Water Quality Monitoring stations from CIMS. The stations are a composite of Maryland and Virginia's fixed station water quality monitoring network and the calibration and swapout data (i.e., swap out data is data collected when in situ water quality monitoring meters are switched for maintenance) from their shallow-water monitoring programs (i.e., continuous monitoring and DATAFLOW ${ }^{1}$ spatially intensive monitoring). The Chesapeake Bay Program supported monitoring data is relatively extensive in time with a 23 -year history, however, the temporal density of the fixed station network is biweekly to monthly and spatial distribution of stations is not particularly dense to meet all Chesapeake Bay water quality criteria assessment needs. Therefore, ancillary data of sufficient quality is desirable and recommended for use when available to enhance the attainment assessments, especially where CBP data are limited or lacking.

Ancillary data derived outside of the Chesapeake Bay Program supported water quality monitoring program that were considered to have sufficient quality, passing rigorous quality assurance/quality control standards, were added to the CIMS data. Examples of additional water quality monitoring data were those data provided by

\footnotetext{
'DATAFLOW: A field sampling technology used on a boat while a watercraft is underway that collects spatially intensive data (hence DATA) for five environmental parameters (water temperature, salinity, dissolved oxygen, turbidity (ntu), and fluorescence (used to estimate chlorophyll a) collected from a flow-through (hence FLOW) stream of water collected near the surface of the water column. The following website provides additional details about DATAFLOW and water quality monitoring with DATAFLOW: http://mddnr.chesapeakebay.net/sim/index.cfm .
} 
Virginia authorities for the 2008 303d/305b listing analyses that were collected from the Virginia Chesapeake Bay benthic monitoring program and the Alliance for the Chesapeake Bay's (ACB) Virginia volunteer monitoring program.

\section{PYCNOCLINE DEFINITION AND BOUNDARIES}

\section{REVISING DESIGNATED USES BOUNDARIES WITH ENHANCED PYCNOCLINE DEFINITION PROCEDURE}

In U.S. EPA (2003a) Ambient Water Quality Criteria for Dissolved Oxygen, Water Clarity and Chlorophyll a for the Chesapeake Bay and Its Tidal Tributaries (Regional Criteria Guidance), EPA identified five habitats (or designated uses) providing a context for adequately protective Chesapeake Bay water quality criteria. Water quality criteria and assessment procedures were developed for dissolved oxygen, water clarity and chlorophyll $a$, published (U.S. EPA 2003a, 2004a,b, 2007a,b), and have progressively been adopted into State water quality standards regulations. The five designated uses were 1) migratory fish spawning and nursery designated use, 2) shallow-water bay grass designated use, 3) open-water fish and shellfish designated use, 4) deep-ivater seasonal fish and shellfish designated use and 5) deep-channel seasonal refuge designated use (U.S. EPA 2003b). EPA published Technical Support Document for Identification of Chesapeake Bay Designated Uses and Attainability (U.S. EPA 2003b, 2004b) which provided further information on the development and geographical extent of the designated uses to which the criteria may apply. Refinements to boundary definitions involving open water, deep water and deep channel have been developed, as described below, to standardize layer definitions.

\section{CALCULATION OF UPPER AND LOWER PYCNOCLINES FOR DISSOLVED OXYGEN DESIGNATED USE CRITERIA ASSESSMENT}

Vertical stratification is foremost among the physical factors affecting dissolved oxygen concentrations in some parts of Chesapeake Bay and its tidal tributaries. For the purposes of water quality criteria attainment assessment, three layers are defined for designated use assessments: 1) an upper mixed layer above the upper pycnocline boundary; 2) deep water layer constrained by the upper and lower pycnocline boundaries; and 3) the lower mixed layer below the lower pycnocline boundary (U.S. EPA 2003a, 2003b). The depths of the upper and lower mixed layers are used to determine designated use boundaries for the dissolved oxygen assessment. In segments where deep water and deep channel habitats are applicable, deep channel is defined as the lower mixed layer, open water is defined as the upper mixed layer, and deep water is the interpycnocline layer between the upper and lower mixed layers.

Temperature $\left({ }^{\circ} \mathrm{C}\right)$ and salinity (ppt) are used to calculate density which, in turn, is used to calculate pycnocline boundaries. Density is calculated using the method described in:

Algorithms for computation of fundamental properties of seawater. Endorsed by UNESCO/SCOR/ICES/IAPSO Joint Panel on Oceanographic Tables and Standards and SCOR Working Group 51. Fofonoff, N P; Millard, R C Jr. UNESCO technical papers in marine science, Paris, no. 44, pp. 53. 1983. 
For each vertical column of temperature and salinity data throughout the water column, the existence of the upper and lower pycnocline boundaries are determined by looking for the shallowest robust vertical change in density greater than 0.1 $\mathrm{kg} / \mathrm{m}^{3} / \mathrm{m}$ for the upper boundary and deepest change of greater than $0.2 \mathrm{~kg} / \mathrm{m}^{3} / \mathrm{m}$ for the lower boundary. To be considered robust, the density gradient must not reverse direction at the next measurement and must be accompanied by a change in salinity and temperature.

Upper and lower pycnocline boundaries, where present, are interpolated in two dimensions. The depth to the upper pycnocline boundary tends to be stable across horizontal space in the estuary and so spatial definition of that boundary using interpolation generally works well. However, interpolation of the lower boundary is more complicated because the results can conflict with 1) the upper boundary definition or 2) with the actual bathymetry of the Bay. As a result, interpolation of the lower boundary should be performed based on "fraction of water column depth".

In the computations, the lower pycnocline is actually stored as "fraction of water column below lower pycnocline," and calculated by dividing the lower pycnocline depth by the total depth and subtracting the product from 1 as follows:

Example: $\quad$ Lower pycnocline depth $=10 \mathrm{~m}$ Total depth $=15 \mathrm{~m}$

$\%$ of total depth below lower pycnocline $=1-(10 / 15)=\sim .333$ or about $33 \%$.

When counting violations, the measures are converted back into an actual depth before comparing measurements to it. To locate the lower pycnocline, multiply the total depth at the given measurement location for that day by (1-\%below lower pycnocline), in this example it is $15(1-.33)=10.01$.

This calculation produces essentially the same depth of lower pycnocline. It is important to proceed in this approach since total depth measurements may differ across sampling dates. By following this procedure for working with the lower pycnocline calculation it avoids the case where you could have a lower pycnocline value below the total depth. If no lower boundary is detected then the fraction is zero.

The standardized method for calculating upper and lower boundaries of the pycnocline uses water column measurements of water temperature and salinity. Ambient Water Quality Criteria for Dissolved Oxygen, Water Clarity and Chlorophyll a for Chesapeake Bay and its Tributaries - 2004 Addendum (U.S. EPA 2004a) provided two basic rules for determination of pycnocline depth:

1. From the water surface downward, the first density slope observation that is greater than $0.1 \mathrm{~kg} / \mathrm{m}^{3} / \mathrm{m}$ is designated as the upper pycnocline boundary provided that:

a. That observation is not the first observation in the water column and

b. The next density slope observation is positive.

2. From the bottom sediment-water interface upward, the first density slope observation that is greater than $0.2 \mathrm{~kg} / \mathrm{m}^{3} / \mathrm{m}$ is designated as the lower pycnocline depth provided that:

a. An upper pycnocline depth exists; 
b. There is a bottom mixed layer, defined by the first or second density slope observation from the bottom sediment-water interface being less than 0.2 $\mathrm{kg} / \mathrm{m}^{3} / \mathrm{m}$

c. The next density slope observation is positive.

U.S. EPA (2004a, see pg. 87) also provided the procedure for calculation of the vertical density profile.

These two decision rules remain unchanged. The detailed step-by-step procedure for applying the two decision rules has been provided here.

Determining the vertical density gradient and defining pycnocline depths requires a vertical profile of salinity and water temperature measurements collected at multiple depths and computed as follows:

1. Sort the vertical profile of data from the water surface downwards through the water column.

2. For each depth at which there are measurements, calculate a water density value as $\sigma \mathrm{T}$, or "sigma T", using water temperature and salinity measurements for that depth. Use the following method and equations:

$$
\begin{aligned}
& \sigma \mathrm{T}=\mathrm{a}(\mathrm{T})+\mathrm{b}(\mathrm{T}) * \mathrm{~S}, \text { where: } \\
& \mathrm{T}=\text { temperature }\left({ }^{\circ} \mathrm{C}\right) \\
& \mathrm{S}=\text { salinity }(\mathrm{ppt}) \\
& \mathrm{a} \text { and } \mathrm{b} \text { are polynomial functions of } \mathrm{T} \\
& \mathrm{a}(\mathrm{T})=-9.22 \times 10^{-3}+5.59 \times 10^{-2} * \mathrm{~T}-7.88 \times 10^{-3} * \mathrm{~T}^{2}+4.18 \times 10^{-5} * \mathrm{~T}^{3} \\
& \mathrm{~b}(\mathrm{~T})=8.04 \times 10^{-1}-2.92 \times 10^{-3} * \mathrm{~T}+3.12 \times 10^{-5} * \mathrm{~T}^{2}
\end{aligned}
$$

3. Look down through the profile. Wherever the difference between sequential depth measurements is $<0.19$ meters, average the two depth measurements and their corresponding salinity and density measurements.

4. Look down through the profile again. If there are still any depths (depth, salinity, temperature and density measurements $)<0.19$ meters apart, then average them again. Continue until there are no depths $<0.19$ meters apart.

5. Starting at the surface measurement and continuing until the deepest measurement in the profile, calculate the change in salinity and density between each sampling depth. For example, for two density values at 1 meter depth $\left(\mathrm{y}_{1}\right)$ and 2 meters depth $\left(\mathrm{y}_{2}\right)$ respectively, the change in density, or $\Delta \sigma \mathrm{T}=\mathrm{y}_{2}-\mathrm{y}_{1}$. Likewise, for salinity measurements $\Delta S=\mathrm{y}_{2}-\mathrm{y}_{1}$.

6. Assign a depth measurement to each pair of $\Delta$ values $(\Delta \mathrm{S}, \Delta \sigma \mathrm{T})$ equal to the average of two depths $x_{2}$ and $x_{1}$ used to calculate the $\Delta$ values. Thus for the two measurements $y_{2}$ and $y_{1}$, calculate the accompanying depth as $\left(x_{1}+x_{2}\right) / 2$. You should now have a vertical profile of $\Delta S$ and $\Delta \sigma \mathrm{T}$ values with an accompanying depth.

7. To find the upper boundary of the pycnocline, look at the vertical profile of $\Delta \sigma \mathrm{T}$, beginning with the second value (from the surface) and excluding the two deepest values:

a. IF $\Delta \sigma \mathrm{T}>0.1$,

b. AND IF $\Delta \sigma \mathrm{T}$ for the next depth is greater than zero, 
c. AND IF $\triangle \mathrm{S}>0.1$,

d. Then this depth represents the upper boundary of the pycnocline.

8. Identify whether there is a lower mixed layer: use the same vertical profile but examine it from the second deepest value upward (exclude the deepest value):

a. IF change in density $(\Delta \sigma \mathrm{T})$ at the second deepest depth $<0.2$

b. OR IF $\Delta \sigma$ T at the next depth (moving upwards, i.e. shallower) $<0.2$

c. THEN a lower mixed layer (i.e. a layer at depth where the density is not changing) below the pycnocline exists.

9. If a lower mixed layer exists, then look for the lower boundary of the pycnocline. Beginning at the second deepest value, and stepping up to the depth immediately below the upper pycnocline boundary, for $\Delta \mathrm{S}$ and $\Delta \sigma \mathrm{T}$ values at each depth:

a. IF $\Delta \sigma \mathrm{T}>0.2$,

b. AND IF $\Delta S>0.1$,

c. Then this depth is the lower pycnocline boundary.

10. If a pycnocline exists, then the upper and lower (if present) boundaries of the pycnocline have now been identified.

\section{LITERATURE CITED}

U.S. Environmental Protection Agency. 2003a. Ambient Water Quality Criteria for Dissolved Oxygen, Water Clarity and Chlorophyll a for the Chesapeake Bay and Its Tidal Tributaries (Regional Criteria Guidance) April 2003. EPA 903-R-03-002. Region III Chesapeake Bay Program Office, Annapolis, MD.

U.S. Environmental Protection Agency. 2003b. Technical Support Documentation for Identification of Chesapeake Bay Designated Uses and Attainability. October 2003. EPA 903-R-03-004. Region III Chesapeake Bay Program Office, Annapolis, MD.

U.S. Environmental Protection Agency. 2004a. Ambient Water Quality Criteria for Dissolved Oxygen, Water Clarity and Chlorophyll a for the Chesapeake Bay and Its Tidal Tributaries 2004 Addendum. EPA 903-R-04-005. Region III Chesapeake Bay Program Office, Annapolis, MD.

U.S. Environmental Protection Agency. 2004b. Technical Support Document for Identification of Chesapeake Bay Designated Uses and Attainability - 2004 Addendum. October 2004. Region III Chesapeake Bay Program Office. EPA 903-R-04-006. Annapolis, MD.

U.S. Environmental Protection Agency. 2007a. Ambient Water Quality Criteria for Dissolved Oxygen, Water Clarity and Chlorophyll a for the Chesapeake Bay and Its Tidal Tributaries 2007 Addendum. July 2007. EPA 903-R-07-003. Region III Chesapeake Bay Program Office, Annapolis, MD.

U.S. Environmental Protection Agency. 2007b. Ambient Water Quality Criteria for Dissolved Oxygen, Water Clarity and Chlorophyll a for the Chesapeake Bay and Its Tidal Tributaries -Chlorophyll a Addendum. October 2007. EPA 903-R-07-005. Region III Chesapeake Bay Program Office, Annapolis, MD. 


\section{chapter IV}

\section{Refinements to Procedures for Assessing Chesapeake Bay Water Clarity and SAV Criteria}

\section{BACKGROUND}

With the publication of the Ambient Water Quality Criteria for Dissolved Oxygen, Water Clarity and Chlorophyll a for the Chesapeake Bay and its Tidal Tributaries (Regional Criteria Guidance) (U.S. EPA 2003a) and the Technical Support Document for Identification of Chesapeake Bay Designated Uses and Attainability (Technical Support Document) (U.S. EPA 2003b), the jurisdictions were provided with extensive guidance for how to determine attainment of the shallow-water bay grass designated use. Additional guidance addressing 1) water clarity criteria application periods, 2) SAV restoration acreage to shallow-water habitat acreage ratios, 3) SAV restoration goal acreages and 4) determining attainment of shallow-water bay grass use was further provided by Ambient Water Quality Criteria for Dissolved Oxygen, Water Clarity and Chlorophyll a for the Chesapeake Bay and its Tidal Tributaries - 2004 Addendum (U.S. EPA 2004). Additional details of water clarity criteria and SAV restoration acreage attainment assessments were published in the Ambient Water Quality Criteria for Dissolved Oxygen, Water Clarity and Chlorophyll a for the Chesapeake Bay and its Tidal Tributaries - 2007 Addendum (U.S. EPA 2007).

Since publication of the U.S. EPA 2007 Addendum, the following specific revisions have been agreed upon by the Chesapeake Bay Program partners:

- Revision of the water clarity acres assessment methodology;

- Clarification on the method for calculation of water clarity acres;

- Clarification on the statistical model involved in converting turbidity to $\mathrm{K}_{d}$; and

- Development of the interpolation approach.

Water clarity criteria and SAV restoration acreages are used to define attainment of the shallow-water bay grass designated use in Chesapeake Bay, its tidal tributaries 
and embayments. EPA provided three measures for assessing attainment of the shallow-water Bay grass designated use for a Chesapeake Bay segment:

1. measure SAV acreage from overflight data mapping analysis and compare with the targeted restoration goal acreage of SAV in a given segment;

2. goal attainment may be achieved if sufficient shallow-water area with the water clarity necessary to achieve restoration of the targeted SAV exists, based on routine water quality mapping using data from the Chesapeake Bay shallowwater monitoring program. This measurement concept is defined as "water clarity acres" (see p. 54, U.S. EPA 2007); and

3. if the water-clarity criteria were attained through the shallow-water designated use reaching to a specific contour (i.e., segment-specific water clarity criteria application depth) based on the cumulative frequency diagram assessment methodology, again based on shallow-water monitoring program data (U.S. EPA 2003a, 2003b, 2007).

Assessment of either SAV acreage, water clarity acres, or a combination of both, serves as the basis for determining attainment or impairment of the shallow-water designated use (U.S. EPA 2007). In the absence of sufficient shallow-water monitoring data to determine the available water clarity acres or assess water clarity criteria attainment using the CFD-based procedure, the EPA recommends that the states assess shallow-water bay grass designated use attainment based on the acres of mapped SAV (see Chapter 8 of U.S. EPA 2007).

\section{REVISION OF THE WATER CLARITY ACRES ASSESSMENT METHODOLOGY}

Revision of the water clarity acres assessment methodology involves clarification of the attainment method previously published in 2007 (U.S. EPA 2007). The 2007 published attainment method recommended assessments to be made from a mean of annual means for three years of assessments (see p. 54). The revised methodology evaluates each year in the three-year cycle for a single best year attainment evaluation of segment restoration goals. This attainment assessment framework could be used when mapped SAV acres alone do not meet its restoration goal and as an alternative to the CFD-based water clarity criteria assessment method (Table IV-1).

The detailed standard operating procedures (SOPs) that define the detailed computer workstation methods used in each State from the import of data through data processing, regression calculations, interpolations and attainment assessment are available from Maryland and Virginia (Maryland Department of Natural Resources 2008, Virginia Departments of Environmental Quality 2008). These specific SOPS are updated with computer coding revisions that maintain the standard baywide framework of the criteria assessment methodology but acknowledge such State specific issues as changes with new software and software updates, new data sources and programming efficiency updates to accomplish the tasks. 


\section{CLARIFICATION OF WATER CLARITY ASSESSMENT PROCEDURES}

U.S. EPA 2007, on pages 54-55, stated "Calculation of water clarity acres should be based on spatially intensive shallow-water monitoring turbidity data converted to $\mathrm{K}_{\mathrm{d}}$, interpolated as described in Chapter 2 and then compared to the corresponding $K_{d}$ threshold assigned to each interpolator grid cell". A 2007 review of the published language, however, found this did not correctly capture the approach to obtaining the $\mathrm{K}_{\mathrm{d}}$ attainment assessment when using water clarity acres. An analysis (Appendix C) conducted by the Chesapeake Bay Program partners shows the two methods did not produce dramatically different results for the selected example cruise tracks, but the analysis did suggest that:

1. The originally published guidance method was simpler to conduct than this revised method which requires GIS-related software;

2. The revised method predicts with slightly less error; and

3. The revised method allows detection of spatial patterns in the individual parameters including better depiction of areas of uncertainty due to, for example, interpolation across land.

The following revisions, which have been made by the Criteria Assessment Protocol Work Group under the U.S. EPA Chesapeake Bay Monitoring and Analysis Subcommittee, are clarifications of the published methods used by the jurisdictions for calculating water clarity acres.

\section{STATISTICAL MODEL REVISION}

The original publication of the statistical model suggested a multiplicative model of turbidity, chlorophyll and salinity was appropriate for converting turbidity to $\mathrm{K}_{\mathrm{d}}$. The regional regressions are, however, additive multiple regression equations. The generalized form of such a model has been provided in Table IV-1 with an expression that captures the region specific coefficients, exponents involved in the root for turbidity and recognition of region-specific constants in accordance with what the jurisdictions are using to fulfill their assessments.

Shallow-water habitat area acreage goals have been previously defined for water clarity acres as $2.5 \mathrm{x}$ each SAV acre needed to meet the SAV restoration goal acreage (p. 54, U.S. EPA 2007). Segment-specific SAV restoration goal acreages were previously published in U.S. EPA 2003a, 2004 and 2007.

\section{CONVERTING TURBIDITY TO $K_{d}$ FOR CALCULATION OF WATER CLARITY ACRES}

On pages 54-55, U.S. EPA (2007) recommended "Calculation of water clarity acres should be based on spatially intensive shallow-water monitoring turbidity data converted to $K_{d}$ ". To address the issue of converting turbidity measures into $K_{d}$ values, multiple regression equations were derived for determining light attenuation 
Table IV-1. Revisions to Water Clarity Acres Attainment Assessment Methodology.

\section{Procedure}

Assessment calculation
2007 Addendum

U.S. EPA 2007, p54. "Assessment of attaining a segment's water clarity restoration acreage should be based on a calculation of the arithmetic mean of the year-by-year means of a month-bymonth accounting of water clarity acres over the three year SAV growing season assessment period."
Assessment calculation and interpolation
U.S. EPA 2007, p54-55. "Calculation of water clarity acres should be based on spatially intensive shallow-water monitoring turbidity data converted to $\mathrm{K}_{\mathrm{d}}$. interpolated as described in Chapter 2 and then compared to the corresponding $\mathrm{K}_{\mathrm{d}}$ threshold assigned to each interpolator grid cell."

U.S. EPA 2007, p80, "The very dense in siru measurements of turbidity from each sampling cruise track are first converted to $K_{d}$. The natural $\log$ of the converted $K_{d}$ values are then interpolated using a standardized ordinary kriging procedure with $\mathrm{ARC/GIS}$ into a 25 -meter square grid over the segments entire surface area. Once interpolated, the resultant interpolated $\mathrm{K}_{\mathrm{d}}$ values are transformed back."
2008 Addendum

Water clarity acres for the segment are calculated by the taking the annual mean of the monthly acreage within the SAV growing season. Single best year assessments are compared with segment SAV/Water Clarity restoration acreage goals.
Calculation of water clarity acres should be based on spatially intensive shallow-water monitoring data for turbidity, chlorophyll $a$ and salinity in order to convert results to $\mathrm{K}_{\mathrm{d}}$. Within each segment, the individually interpolated chlorophyll, turbidity, and salinity layer grid results are input into the appropriate equation on a matching $25-\mathrm{m}^{2}$ cell-by-cell basis. The result of this cell-specific calculation of $K_{d}$ is based on region-specific multiple regression model equations (Table IV2. Appendix D). The result is a new grid representing the $\mathrm{K}_{d}$ surface. The $\mathrm{K}_{\mathrm{d}}$ grid is compared to the appropriate $K_{d}$ threshold on a cell-by-cell basis to create the attainment grid. The attainment grid results are stored in a database and used to calculate water clarity acres by initially converting cell counts of attainment into acreage of attainment inside and outside of current mapped SAV areas for each segment. As previously defined, attainment evaluations account for any SAV no grow zones by removing them before conducting final calculations for the segment (U.S. EPA 2007). Water clarity acres for each segment are then calculated by taking the annual mean of the monthly acreages. 
Table IV-1. (continued).

\begin{tabular}{|c|c|c|}
\hline Procedure & 2007 Addendum & 2008 Addendum \\
\hline $\begin{array}{l}\text { Statistical Modeling: Turbidity-to- } \mathrm{K}_{\mathrm{d}} \\
\text { conversion }\end{array}$ & $\begin{array}{l}\text { U.S. EPA 2007, p79. Statistical } \\
\text { Modeling - Model definition and } \\
\text { regionally specific models. "A multiple } \\
\text { regression model of } \mathrm{K}_{\mathrm{d}} \text { vs. } 1.5 \text { root of } \\
\text { turbidity [i.e., turbidity }{ }^{1 / 1.5} \text { ] } x \\
\text { chlorophyll } x \text { salinity provides the best } \\
\text { fit of the } \mathrm{K}_{\mathrm{d}} \text {-to-turbidity relationship". }\end{array}$ & $\begin{array}{l}\text { A multiple regression model of } \mathrm{K}_{\mathrm{d}} \mathrm{vs} \text {. } \\
\left.1.5 \text { root of turbidity [i.e.. turbidity }{ }^{1 / 1.5}\right] \\
+ \text { chlorophyll } a+\text { salinity provides the } \\
\text { best fit of the } \mathrm{K}_{\mathrm{d}} \text {-to-turbidity } \\
\text { relationship. The general form of the } \\
\text { models then are } \mathrm{K}_{\mathrm{J}}=\left(\mathrm{x}^{*} \text { turbidity }{ }^{\mathrm{a}}\right)+ \\
\left(\mathrm{y}^{*} \text { chlorophyll }{ }^{\mathrm{b}}\right)+\left(\mathrm{z}^{*} \text { salinity }\right)+\mathrm{C} \\
\text { where: } \\
\text { - a,b and } \mathrm{c} \text { are exponents on } \\
\text { their respective water quality } \\
\text { parameters and a=(1/l.5), b=1 } \\
\text { and } \mathrm{c}=1 \text {; } \\
\text { - } \mathrm{x}, \mathrm{y} \text { and } \mathrm{z} \text { are region-specific } \\
\text { constant multipliers for the } \\
\text { respective three water quality } \\
\text { parameters defined in Table IV-2; } \\
\text { - C is a region-specific constant; } \\
\text { and } \\
\text { - Turbidity is measured in NTUs, } \\
\text { chlorophyll } a \text { is reported in ug/L } \\
\text { and salinity measures are taken in } \\
\text { parts per thousand (ppt). }\end{array}$ \\
\hline
\end{tabular}

$\left(\mathrm{K}_{\mathrm{d}}\right)$ using in situ $\mathrm{K}_{\mathrm{d}}$ calibration measurements and coincident continuous water quality monitoring data. A single equation for baywide application was not found to be appropriate (Appendix D). Rather, a series of regionally-specific multiple regression models for determining light attenuation $\left(K_{d}\right)$ from turbidity, chlorophyll and salinity data were developed (Table IV-2). Details of the regionally-specific regression equation derivations supporting their application for turbidity conversion to $\mathrm{K}_{\mathrm{d}}$ throughout Chesapeake Bay and its tidal tributaries and embayments are documented in Appendix D.

Turbidity conversion to a $K_{d}$ measure is not a 1:1 unit conversion. On page 79, U.S. EPA (2007) specifically discussed the multiple regression model approach but initially provided a multiplicative form of a general equation where $K_{d}=1.5$ root of turbidity $x$ chlorophyll a $x$ salinity as providing the best fit to the $\mathrm{K}_{\mathrm{d}}$-turbidity relationship. Table IV-2 provides the updated additive form of the regression model and region-specific groupings of tributaries as defined through State-specific cluster analyses in Maryland and Virginia. Virginia-specific analyses were the first completed and published the use of the 1.5 root for turbidity conversion to $\mathrm{K}_{\mathrm{d}}$ (U.S. EPA 2007). Maryland-specific analyses showed that a 1.6 root yielded the lowest root mean square prediction error and highest r-square value. However, this difference in root, the associated error and r-square for the $1.5 \mathrm{vs} .1 .6$ root associated with turbidity- $K_{d}$ conversion were so minor (i.e., thousandths-decimal-place differences) that it was decided for consistency across the jurisdictions to use the results for the 
1.5 root (Appendix D). The regression equations in Table IV-2 provide regional groupings and their regionally appropriate coefficients.

Note that the equations in Table IV-2 represent regions that pertain to a subset (30) of the 92 Chesapeake Bay assessment segments. These equations were developed with the best available shallow-water monitoring data throughout the Chesapeake Bay. As data becomes available with future monitoring applied to other segments, the specific groupings and their respective equations can be expected to change in the future as a result of new data from the unassessed regions.

\section{INTERPOLATION SOFTWARE AND APPROACH}

Monthly shallow water monitoring dataflow data can be imported into ArcGIS 9.2 (ESRI 2007) map visualization software as a point dataset or as a layer in ESRI's ArcMap Geostatistical Analyst Extension. A single point dataset consists of a single DATAFLOW cruise, typically representing a single Chesapeake Bay segment. Each point in the dataset has an associated measured value for chlorophyll, dissolved oxygen, $\mathrm{pH}$, salinity, temperature, and turbidity. A cruise track typically contains $3000-5000$ points with a range of approximately 2500-6000 georeferenced locations. The data are generally collected from April through October with 1-2 cruises per month. Within a cruise dataset, duplicate data values for a georeferenced point in time are averaged. This is important for ArcInfo because in the present ArcInfo workstation environment when kriging is conducted, ArcInfo cannot work with duplicate points. However, kriging conducted in ArcMap's Geostatistical Analyst has the capacity to deal with duplicate data and the same step is not necessary. Missing data are provided with an error code (e.g., Virginia uses a value of -999).

As previously documented in Table IV-1, for the attainment assessment, U.S. EPA (2007, pp. 54-55) indicated "Calculation of water clarity acres should be based on spatially intensive shallow-water monitoring turbidity data converted to $\mathrm{K}_{d}$ ", but the discussion further indicates "interpolated as described in Chapter 2, and then compared to the corresponding $\mathrm{K}_{\mathrm{d}}$ threshold assigned to each interpolator grid cell". Chapter 2 (U.S. EPA 2007 p.11) provided a step-by-step approach to how the interpolation would proceed if only a single parameter is involved in the assessment (e.g., dissolved oxygen for dissolved oxygen attainment measures). However, turbidity is not equivalent to or directly translated into $\mathrm{K}_{\mathrm{d}}$. The regionally-specific multiple regression model approach (see Table IV-2) requires additional steps to get from water quality measure to threshold assessment for attainment or impairment.

Details of the water clarity assessment framework, including a step-by-step approach to assessing attainment, are provided in Appendix E. Appendix F shows 2008 Maryland and Virginia 303d/305b Chesapeake Bay water clarity assessment results to provide examples of water quality criteria attainment assessment output. 
Table IV-2. Regional $K_{d}$ regression equations.

\begin{tabular}{ll}
\hline State-River segment Group & Regional $K_{d}$ equation \\
\hline MARYLAND GROUP 1 & $K_{j}=0.5545+0.3172 *$ Turbidity $(1 / 1.5)+0.0160 *$ Chlorophyll $a-$ \\
Bush River BSHOH. & $0.0138 *$ Salinity \\
Gunpowder River GUNOH. & \\
Magothy River MAGOH. & \\
Middle River MIDOH. & \\
St. Mary's River & \\
\hline
\end{tabular}

\section{MARYLAND GROUP 2}

Eastern Bay-EASMH

Lower Patuxent River-PAXMH

Lower Potomac River-POTMH

West/Rhode Rivers-WSTMH/RHDMH

\section{MARYLAND GROUP 3}

Fishing Bay/Chicamacomico River-

FSHMH. Severn River-SEVMH

South River-SOUMH

\section{MARYLAND GROUP 4}

Little Choptank River-LCHMH

Miles/Wye Rivers-EASMH

\section{MARYLAND GROUP 5}

Upper and Middle Patuxent River$\mathrm{PAXOH} / \mathrm{PAXTF}$

\section{MARYLAND GROUP 6}

Lower Chester River-CHSMH

Middle Chester River-CHSOH

\section{VIRGINIA GROLP}

Mattoponi River-MPNOH/MPNTF

Chickahominy River-CHKOH

James River-JMSPH JMSOH

JMSMH J.MSTF1 JMSTF2

Appomatox River-APPTF

\section{VIRIGINIA GROUP 2}

Upper Middle Pamunkey River-PMKOH PMKTF

Lower York River-YRKPH YRKMH

Lower Piankatank River-PlA.MH
$\mathrm{K}_{\mathrm{J}}=-0.1247+0.2820 *$ Turbidity ${ }^{(1 / 1.5)}+0.0207 *$ Chlorophyll $a+$ $0.0515 *$ Salinity
$\mathrm{K}_{\mathrm{d}}=1.0895+0.4160 *$ Turbidity ${ }^{(1 / 1.5)}+0.0140 *$ Chlorophyll $a-$ $0.0950 *$ Salinity

Source: E. Perry (2006) Appendix D of this document.

Note: Group acronvms are a combination of river and salinity zone membership. An example is BSHOH where BSH=Bush River and

$\mathrm{OH}=$ Oligohaline zone. Salinity zones are TF=Tidal Fresh. $\mathrm{OH}=$ Oligohaline. $\mathrm{MH}=$ Mesohaline. $\mathrm{PH}=$ Polyhaline. Refer to Table II- $\mathrm{I}$. in

Chapter 2 of this document. for the Chesapeake Bay Program segmentation schemes. 


\section{LITERATURE CITED}

Perry, Elgin. (2006). Notes on Lumping vs Splitting $K d=f($ turbidity) calibration. Appendix $\mathrm{D}$ in this Addendum.

Environmental Systems Research Institute (ESRI). 2007. ArcGIS 9.2. Redlands, CA.

Maryland Department of Natural Resources. 2008. Water Clarity Calculation SOP 2008. Tidewater Ecosystem Assessment, Annapolis, MD.

U.S. Environmental Protection Agency. 2003a. Ambient Water Quality Criteria for Dissolved Oxygen, Water Clarity and Chlorophyll a for the Chesapeake Bay and Its Tidal Tributaries (Regional Criteria Guidance). April 2003. EPA 903-R-03-002. Region III Chesapeake Bay Program Office, Annapolis, MD.

U.S. Environmental Protection Agency. 2003b. Technical Support documentation for identification of Chesapeake Bay designated uses and attainability. October 2003. EPA 903-R-03-004. Region III Chesapeake Bay Program Office, Annapolis. MD.

U.S. Environmental Protection Agency. 2004. Ambient Water Quality Criteria for Dissolved Oxygen, Water Clarity and Chlorophyll a for the Chesapeake Bay and Its Tidal Tributaries 2004 Addendum. EPA 903-R-04-005. Region III Chesapeake Bay Program Office, Annapolis, MD.

U.S. Environmental Protection Agency. 2007. Ambient Water Quality Criteria for Dissolved Oxygen, Water Clarity and Chlorophyll a for the Chesapeake Bay and Its Tidal Tributaries 2007 Addendum. July 2007. EPA 903-R-07-003. Region III Chesapeake Bay Program Office, Annapolis, MD.

Virginia Department of Environmental Quality. 2008. Water Clarity Calculation SOP 2008. 


\section{chapter \\ Chlorophyll a Criteria Assessment Procedures}

\section{BACKGROUND}

Phytoplankton are small often microscopic plants floating in the water. These organisms form the base of the Chesapeake Bay's food web, linking nutrients and sunlight energy with higher trophic levels such as fish (e.g. menhaden, bay anchovy) and with bottom dwelling oysters, clams and worms via primary producer and detrital pathways. The majority of the Bay's animals feed directly on phytoplankton or on organisms that directly consume the phytoplankton. Therefore, the Bay's carry capacity, or its ability to produce and maintain a diversity of species, depends in large part on how well phytoplankton meet the needs of the consumers.

A primary characteristic of algae is the presence of photopigments. Chlorophyll $a$ is a primary photosynthetic pigment in algae and cyanobacteria (blue-green algae). Since chlorophyll $a$ is a measure of photosynthetic activity, it is thus also a measure of the primary food source of aquatic food webs. Chlorophyll $a$ also plays a direct role in reducing light penetration in shallow-water habitats, which has a direct impact on underwater bay grasses. Excess algae, uneaten by higher trophic level consumers (e.g., zooplankton, filter-feeding fish and shellfish), are decomposed by bacteria, and in the process, exert a biological oxygen demand upon the system. Decomposition of the algal organic matter through bacterial respiration can remove oxygen from the water column faster than it can be replaced and lead to hypoxia and anoxia, impairing habitat conditions for much of the Bay life. From a water quality perspective, chlorophyll $a$ is the best available, most direct measure of the amount and quality of phytoplankton with a relationship to impacts on water clarity and dissolved oxygen impairments.

The EPA originally provided the States with recommended narrative chlorophyll $a$ criteria applicable to all Chesapeake Bay and tidal tributary waters:

"Concentrations of chlorophyll a in free floating microscopic aquatic plants (algae), shall not exceed levels that result in ecologically undesirable consequences-such as reduced water clarity, low dissolved oxygen, food supply imbalances, proliferation of species deemed potentially harmful to aquatic life or humans or aesthetically 
objectionable conditions-or other render tidal waters unsuitable for designated uses." (U.S. EPA 2003a).

However, the EPA also strongly encouraged states to develop and adopt site-specific numerical chlorophyll $a$ criteria for tidal waters where algal-related impairments are expected to persist even after the Chesapeake Bay dissolved oxygen and water clarity criteria have been attained.

In Ambient Water Quality Criteria for Dissolved Oxygen, Water Clarity and Chlorophyll a for the Chesapeake Bay and Its Tidal Tributaries - 2004 Addendum (U.S. EPA 2004) guidance was developed on determining where numerical chlorophyll $a$ criteria should apply to Chesapeake Bay and tidal tributary waters. A general recommended methodology was developed by the Chesapeake Bay Program partners for use by the jurisdictions with tidal waters to determine consistently which local tidal waters will likely attain the published Chesapeake Bay dissolved oxygen and water clarity criteria yet show the persistence of algal-related water quality impairments. Examples of possible salinity-zone-specific, numerical chlorophyll $a$ thresholds $(\mu \mathrm{g} / \mathrm{L})$ drawn from a variety of resources and approaches were provided with derivations based in:

1. historical Chesapeake Bay levels;

2. ecosystem trophic status;

3. phytoplankton reference communities;

4. potentially harmful algal blooms;

5. water quality impairments; and

6. user perceptions and State water quality standards (Table IX-1 in U.S. EPA 2004).

From 2004 through 2006, Delaware, Maryland, Virginia and the District of Columbia promulgated narrative chlorophyll $a$ criteria into their water quality standards. Virginia promulgated numerical segment- and season-specific chlorophyll $a$ criteria for the tidal James River. The District of Columbia promulgated numerical chlorophyll $a$ criteria for its reach for the tidal Potomac River and its remaining waters, having previously adopted numerical criteria for chlorophyll $a$ criteria for the protection of the tidal Anacostia River.

Quantitative interpretation of Maryland's narrative criterion for chlorophyll $a$ is cited in the following excerpt from Maryland Department of the Environment's (MDE's) "Total Maximum Daily Loads of Nitrogen and Phosphorus for the Upper and Middle Chester River Kent and Queen Anne's Counties, Maryland" (approved by U.S. EPA November 2006). The text below also describes MDE's interpretation of this criterion in terms of quantified goals for application in Total Maximum Daily Loads (TMDLs).

The Chlorophyll $a$ level goals used in this analysis are guidelines set forth by Thomann and Mueller (1987) and by the EPA Technical Guidance Manual for Developing Total Maximum Daily Loads, Book 2, Part 1 (1997). The chlorophyll a narrative criteria ((COMAR 26.08.02.03-3 C (10)) states: "Chlorophyll $a$-Concentrations of chlorophyll $a$ in free-floating microscopic aquatic plants (algae) shall not exceed levels that result in ecologically undesirable consequences that would render tidal waters unsuitable for designated uses." The Thomann and Mueller guidelines above acknowledge " 'Undesirable' levels of phytoplankton [Chlorophyll $a$ ] vary considerably 
depending on water body." MDE has determined per Thomann and Mueller (1987), that it is acceptable to maintain chlorophyll $a$ concentrations below a maximum of $100 \mu \mathrm{g} / \mathrm{L}$, and also to target, with some flexibility depending on waterbody characteristics, a 30 -day rolling average of approximately $50 \mu \mathrm{g} / \mathrm{L}$. Consistent with the guidelines set forth above, MDE's interpretation of narrative criteria for chlorophyll $a$ in the Upper and Middle Chester River consists of the following goals:

1. Ensure that instantaneous concentrations remain below $100 \mu \mathrm{g} / \mathrm{l}$ at all times and

2. Minimize exceedances of the $50 \mu \mathrm{g} / \mathrm{l}, 30$-day rolling average, to a frequency that will not result in ecologically undesirable conditions.

Further development of numerical chlorophyll $a$ criteria for Chesapeake Bay tidal waters was advanced with the U.S. EPA 2007b publication Ambient Water Quality Criteria for Dissolved Oxygen, Water Clarity and Chlorophyll a for the Chesapeake Bay and Its Tidal Tributaries - 2007 Chlorophyll Criteria Addendum. This 2007 chlorophyll a criteria addendum documented the scientific basis for numerical chlorophyll criteria based on:

1. historical chlorophyll $a$ reference concentrations;

2. chlorophyll a relationships with dissolved oxygen impairments;

3. chlorophyll $a$ contributions to water clarity impairments; and

4. characteristic chlorophyll a conditions associated with specific impairments related to harmful algal blooms.

Recommendations on Chesapeake Bay chlorophyll $a$ criteria were provided and structured, tiered sample collection, analysis and assessment procedures were recommended. The specific sampling and assessment procedure recommendations are directed toward a harmful algal bloom (HAB) based chlorophyll $a$ criterion that could be applied to the Chesapeake Bay tidal fresh and oligohaline waters.

The basic approach used for numerical chlorophyll $a$ criteria assessment procedure is documented in Table II- 1 in the July 2007 criteria addendum (U.S. EPA 2007a). The details of the chlorophyll $a$ criteria attainment assessment are documented here in Appendix G. The general application example below is illustrated for the James River.

\section{APPROACH AND PROTOCOL APPLICATION WITH EXAMPLES}

The use of spatially and temporally-intensive DATAFLOW data in conjunction with monthly and semi-monthly fixed station data allowed for the generation of daily interpolated estimates for each segment. In Virginia, during the 2008 assessment for example, more than 500,000 data points were used for the assessment of the threeyear period. This monitoring approach produced data that generally resulted in from 1 to 7 individual day-scale interpolation grids in any one month. The day-scale interpolation grids were then used to calculate a seasonal average concentration for each grid cell. This approach ensures that segments are assessed with as much spatiotemporal variability as possible while minimizing reliance on weak estimates stemming from small sample sizes. 
The chlorophyll $a$ criteria attainment assessment procedural steps are as follows:

1. A database was compiled for the three-year assessment period containing the following:

- Long-term CBP stations (records stored in CIMS database);

- DATAFLOW verification stations (records stored in CIMS database);

- DATAFLOW cruise-tracks (records stored by VIMS, HRSD, MD DNR); and

- VA DEQ stations where applicable (records stored in VA DEQ CEDS database).

2. Only data meeting appropriate QA/QC requirements are used in the assessment. Cruise-track data flagged with codes related to equipment failure or sampling artifacts were excluded, while data taken during algal blooms were used.

3. Each segment (e.g., JMSTFL, JMSTFU, JMSOH, JMSMH, and JMSPH refer to Chapter II, Table II- 1 in this document for segment nomenclature and water body names) is interpolated separately using only the stations and cruisetracks contained in them and directly adjacent. Data from a given day is interpolated for a segment if: 1) there were two or more fixed stations sampled on that day in that segment; 2) that segment was targeted by a DATAFLOW cruise-track on that day; or 3 ) there was a fixed station sampled in that segment and an adjacent segment was targeted by a DATAFLOW cruise-track on that day. The last condition takes advantage of cruise-tracks that cross over into multiple Chesapeake Bay Program segments.

4. Datasets are imported into the Chesapeake Bay Interpolator and transformed (natural $\log$ ) prior to interpolation, as chlorophyll a measurements tend to follow a log-normal distribution. The program defaults for search area $\left(25 \mathrm{~km}^{2}\right)$ and maximum sample size (4) are used, and the "2D Inverse-Distance Squared" algorithm is chosen. The Interpolator automatically back-transforms interpolated estimates before creating the output files.

5. Interpolator output was organized by segment-season-year. For each interpolator cell in a segment, a season-year (e.g., Spring 2005) average is calculated.

6. For the VA example, grid-cell averages were then assessed against segmentseason criteria specified by the VA DEQ Water Quality Assessment Guidance Manual for Y2008 303(d)/305(b) Integrative Water Quality Report (VA DEQ 2007). Values over the criteria were assessed as non-attaining; those equal to or less than were assessed as attaining.

7. Seasonal CFDs are generated for each segment using the steps outlined in Chapter 2 of Ambient Water Quality Criteria for Dissolved Oxygen, Water Clarity and Chlorophyll a for the Chesapeake Bay and Its Tidal Tributaries 2007 Addendum (U.S. EPA 2007a). Assessment curves were compared against a default reference curve (U.S. EPA 2003). Non-attainment is calculated by subtracting the area of the reference curve from the area under the chlorophyll $a$ criteria assessment curve.

\section{TYPES OF OUTPUT}

Three types of output were produced for assessment: cumulative frequency distribution diagrams, maps, and tabular summaries (see Figure V-I, Figure V-2, and Table V-l for examples). 

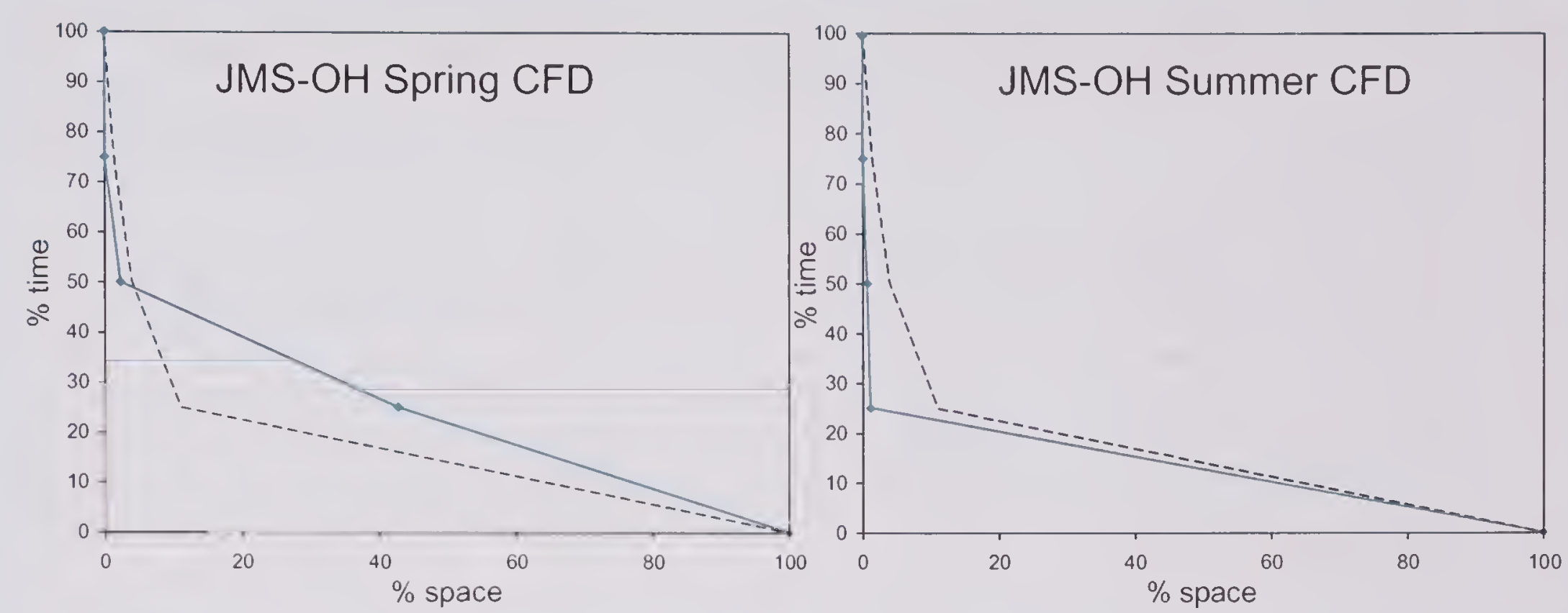

Figure V-1. Cumulative frequency distribution diagrams for each segment and season (Spring and Summer) showing the assessment curve (solid blue line) against the default reference curve (dashed black line).

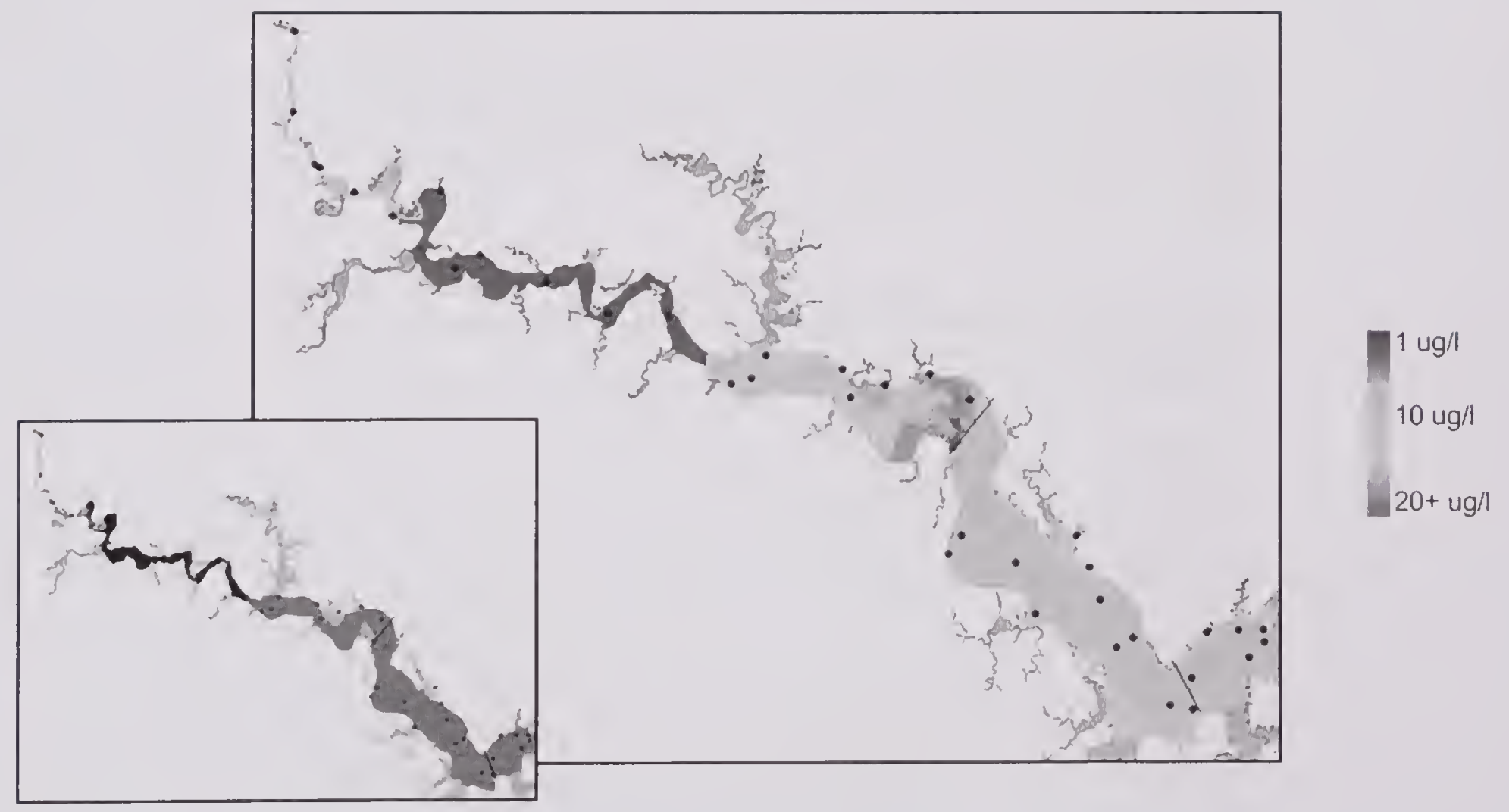

Figure V-2. Example map graphics. Larger map shows the average chlorophyll a concentration $(\mu \mathrm{g} / \mathrm{L})$ in the tidal James River for summer 2006. Dots represent the locations of fixed stations. Inset shows the same data reduced to the assessment binary (grey=pass, black=fail). 
Table V-1. Example summary pass/fail results for chlorophyll a criteria assessment.

CHLOROPHYLL CRITERIA ASSESSMENT RESULTS (2008 INTEGRATED REPORT)

\begin{tabular}{lllc} 
CBP Segment & Season & Criteria Attainment & \% Excess non-attainment \\
\hline JMSTF1 (James TF Lower) & Spring & Fails & 26 \\
JMSTF1 (James TF Lower) & Summer & Fails & 47 \\
\hline JMSTF2 (Jmes TF Upper) & Spring & Fails & 27 \\
JMSTF2 (Jmes TF Upper) & Summer & Fails & 26 \\
\hline JMSOH (James Oligohaline) & Spring & Fails & 8 \\
JMSOH (James Oligohaline) & Summer & Meets & 0 \\
\hline JMSMH (James Mesohaline) & Spring & Fails & 22 \\
JMSMH (James Mesohaline) & Summer & Fails & 2 \\
\hline JMSTPH (James Polyhaline) & Spring & Fails & 29 \\
JMSTPH (James Polyhaline) & Summer & Fails & \\
\hline
\end{tabular}

\section{FUTURE DIRECTIONS}

Extractive chlorophyll $a$ has been shown to significantly exceed fluorescent (YSI probe-based) chlorophyll $a$ measured at verification stations at times (e.g., Virginia James River example), therefore necessitating calibration between the two measurement methods. While regression coefficients were calculated so as to account for season and segment-specific idiosyncrasies, the goodness of fit for the different calibration equations varied (Table V-2).

Table V-2. Root mean square errors for segment-season calibration regressions with extractive and YSI probe-based chlorophyll a measures for tidal James River segments ${ }^{1}$.

\begin{tabular}{lccc}
\hline Segment & Season & $\mathbf{R}^{2}$ & RSME \\
\hline JMSTFU & Spring & 0.59 & 6.21 \\
\hline JMSTFU & Summer & 0.79 & 5.51 \\
\hline JMSTFL & Spring & 0.84 & 4.83 \\
\hline JMSTFL & Summer & 0.92 & 6.80 \\
\hline JMSOH & Spring & 0.68 & 9.54 \\
\hline JMSOH & Summer & 0.23 & 4.46 \\
\hline JMSMH & Spring & 0.96 & 13.28 \\
\hline JMSMH & Summer & 0.95 & 9.05 \\
\hline JMSPH & Spring & 0.69 & 1.84 \\
\hline JMSPH & Sumner & 0.89 & 2.18 \\
\hline
\end{tabular}

'JMSTFU=James River, Tidal Fresh Upper Segment; JMSTFL=James River, Tidal Fresh Lower Segment; JMSOH=James River. Oligohaline Segment: JMSMH=James River, Mesohaline Segment: JMSPH=James River, Polyhaline Segment 
In this example, the best predictions overall were obtained in JMSPH and the worse predictions for JMSMH. As chlorophyll $a$ assessments expand across the tidal waters, additional environmental parameter(s) may need to be used to increase the accuracy of estimates similar to the way $\mathrm{K}_{\mathrm{d}}$ and turbidity relationships turned to additive multivariate models.

An additional consideration is that field data are interpolated without respect to land barriers, which can result in station data having undue influence on distant grid cells. The use of DATAFLOW data cruise-track points minimizes this because of the high density of "nearest neighbors." However, it becomes an issue of concern when cruise-track points are not available in the search radius and the segment of interest has meandering portions (such as JMSTFU). Interpolating with barriers is not an option for the Bay Interpolator at this time, but ArcGIS Geostatistical Analyst for example provides a limited form of this functionality.

\section{LITERATURE CITED}

COMAR 26.08.02.03-3 C (10)). Chlorophyll a narrative criteria.

Thomann, R. V. and J. A. Mueller. 1987. Principles of Surface Water Quality Modeling and Control. Harper \& Row, Publ., Inc., New York, NY.

U.S. Environmental Protection Agency. 1997. Technical Guidance Manual for Developing Total Maximum Daily Loads, Book 2, Part 1. EPA\# 823-B-97-002. Office of Water, Washington, DC.

U.S. Environmental Protection Agency. 2003. Ambient Water Quality Criteria for Dissolved Oxygen, Water Clarity and Chlorophyll a for the Chesapeake Bay and Its Tidal Tributaries. April 2003. EPA 903-R-03-002. Region III Chesapeake Bay Program Office, Annapolis, MD.

U.S. Environmental Protection Agency. 2004. Ambient Water Quality Criteria for Dissolved Oxygen, Water Clarity and Chlorophyll a for the Chesapeake Bay and Its Tidal Tributaries - 2004 Addendum. October 2004. EPA 903-R-03-002. Region III Chesapeake Bay Program Office, Annapolis, MD.

U.S. Environmental Protection Agency. 2007a. Ambient Water Quality Criteria for Dissolved Oxygen, Water Clarity and Chlorophyll a for the Chesapeake Bay and Its Tidal Tributaries - 2007 Addendum. July 2007. EPA 903-R-07-003. Region III Chesapeake Bay Program Office, Annapolis, MD.

U.S. Environmental Protection Agency. 2007b. Ambient Water Quality Criteria for Dissolved Oxygen, Water Clarity and Chlorophyll a for the Chesapeake Bay and Its Tidal Tributaries - 2007 Chlorophyll Criteria Addendum. November 2007. EPA 903R-07-005. Region III Chesapeake Bay Program Office, Annapolis, MD.

Virginia Department of Environmental Quality (VA DEQ). 2007. Water Quality Assessment Guidance Manual for Y2008 303(d)/305(b) Integrative Water Quality Report. Water Quality Division, Office of Water Quality Programs, Virginia Department of Environmental Quality, Richmond, VA. 


\section{Acronyms}

$\begin{array}{ll}\mathrm{ACB} & \text { Alliance for Chesapeake Bay } \\ { }^{\circ} \mathrm{C} & \text { degrees Celcius } \\ \mathrm{CEDS} & \text { Comprehensive Environmental Data System } \\ \mathrm{CFD} & \text { cumulative frequency distribution } \\ \mathrm{CHLA} & \text { chlorophyll } a \\ \mathrm{CIMS} & \text { Chesapeake Information Management System } \\ \mathrm{CBP} & \text { Chesapeake Bay Program }\end{array}$

DATAFLOW A field sampling technology that collects spatially intensive data (hence

DATA) for five environmental parameters (water temperature, salinity, dissolved oxygen, turbidity (ntu), and fluorescence (used to estimate chlorophyll a) are collected from a flow-through (hence FLOW) stream of water collected near the surface of the water column.

DE

Delaware

DFLO

DATAFLOW

EPA

U.S. Environmental Protection Agency

GIS Geographic Information System

HRSD Hampton Roads Sanitation District

$\mathrm{K}_{\mathrm{d}}$ light attenuation measure

$\mathrm{kg} / \mathrm{m}^{3} / \mathrm{m}$

$\mathrm{km}^{2}$ kilograms per cubic meter per meter

LICOR square kilometer

Company name for a sensor used in water quality monitoring that measures underwater photosynthetically active radiation (PAR)

MD Maryland

MD DNR Maryland Department of Natural Resources

$\mathrm{m}^{2}$ square meter

$\operatorname{mg~} \mathrm{O}_{2} / \mathrm{L}$

$\mathrm{NAD}$ milligram dissolved oxygen per liter

NTU North American Datum

ppt nephelometric turbidity units

QA/QC parts per thousand

RSME

SAV quality assurance/quality control root mean square error

SOP submerged aquatic vegetation

TMDL standard operating procedures

$\mu \mathrm{g} / \mathrm{L}$

Total Maximum Daily Load

UTM micrograms per liter

VA Universal Transverse Mercator

VA DEQ Virginia

VIMS Virginia Department of Environmental Quality

YSI Virginia Institute of Marine Science

Yellow Springs Instruments, company producing water quality monitoring sensors 
appendix $\mathbf{Z}$

\section{Procedure for Assessing Dissolved Oxygen Criteria Attainment 30-day Criterion, Including Plotting a Bioreference Curve}

Currently, dissolved oxygen is assessed using the monthly mean criterion (i.e., 30day) for the open-water designated use, the monthly mean criterion for the deep-water designated use, and the instantaneous minimum criterion for the deepchannel designated use. The following step-by-step procedure is used to assess the status of Chesapeake Bay waters with respect to dissolved oxygen.

\section{STEP 1. COMPILING AND FORMATTING THE DATA SET}

A three-year dissolved oxygen dataset is compiled (most recently, the 2008 evaluation used the 2004-2006 assessment period) with georeferenced stations for Chesapeake Bay Program mainstem and tributary tidal waters, and included the date sampled, and coincidently measured water temperature $\left({ }^{\circ} \mathrm{C}\right)$ and salinity (ppt) covariates. Ancillary data for the same parameters were added by the state of Virginia where applicable, collected from their benthic monitoring program and the Alliance for the Chesapeake Bay's Virginia volunteer monitoring program.

A FORTRAN computer program was developed to reformat this flat file into a "d3d file" - a format that could be input into the Chesapeake Bay Program Interpolator.

\section{STEP 2. INTERPOLATION OF WATER QUALITY MONITORING DATA}

For the Chesapeake Bay and its tidal tributaries and embayments, a three-dimensional grid-based spatial interpolator was developed to provide a common spatial framework for spatial extrapolation of georeferenced water quality monitoring data (Bahner 2001). Spatial interpolation is conducted using an inverse distance weighting algorithm that extrapolates point data between itself and its nearest 
neighbors in the spatial unit being considered. Further details regarding the basis of spatial interpolation of water quality monitoring data within the Chesapeake Bay Program segmentation framework are described in Ambient Water Quality Criteria for Dissolved Oxygen, Water Clarity and Chlorophyll a for the Chesapeake Bay and Its Tidal Tributaries (Regional Criteria Guidance), pp.154-157 (U.S. EPA 2003).

Recent updates to the interpolator software have been made and the present program is a Visual Basic program, version 4.61 August 2006, with customized data region and bathymetry files.

\section{STEP 2.1. Vertical Interpolation}

Specific to Chesapeake Bay, in areas > 12 meters, where deep-water and deepchannel designated uses occur, the program uses vertical depth profiles of the water temperature and salinity data for each Chesapeake Bay Program water quality monitoring station to calculate the upper and lower boundaries of the pycnocline.

The program assigns the data from a particular monitoring cruise number by its date and divides the coincidently measured, georeferenced data into separate files for dissolved oxygen, salinity, and pycnocline. The result is a set of files for each parameter that comprise a set of files for each cruise.

The Chesapeake Bay Program interpolator's vertical interpolation function (On the Data Import screen), is run in batch mode to vertically interpolate each data file. The program is used with default settings beginning with a 0.5 meter START DEPTH and applying a 1.0 vertical meter STEP DEPTH.

\section{STEP 2.2. Horizontal Interpolation}

After vertical interpolation, interpolated data is available at scales below the more than 1.0 meter depth-steps from the water quality data collection. To generate a horizontal interpolation of the vertically interpolated data set, the program uses the Interpolate screen. Data files are again processed in batch mode presently using the following settings:

3D inverse-distance squared model

Min \# Neighbors $=1$

Max \# Neighbors $=4$

Horizontal Range $(\max )=99000 \mathrm{~m}$ (essentially only limited by each segment's data region)

Vertical Range $(\min )=0.1 \mathrm{~m}$

Vertical Range $(\max )=0.1 \mathrm{~m}$

Vertical step size $=0.1 \mathrm{~m}$

Missing value $=-9$

A file for each water quality parameter-cruise combination (parameters of dissolved oxygen, temperature and salinity measured coincidently in space and 
time) is produced containing interpolated values for a set of cells representing the bathymetry of Chesapeake Bay (with depths in 1-meter increments).

\section{STEP 2.3. 30-Day Average Interpolations by Month}

A 30-day average is then calculated for each grid cell, for each parameter-cell combination. The output is a set of files for each parameter. Each set of files includes an individual file for each month (e.g., 30-day average interpolation output per month) of the three-year assessment period.

\section{STEP 2.4. Apportioning Results by Designated Use}

Another program uses, in this case, the 30-day average interpolated pycnocline and salinity files (i.e., salinity data that were originally, coincidently measured at the same time of the dissolved oxygen measurements) to first divide the interpolated dissolved oxygen data into separate files for each designated use. Second, the program then applies the appropriate water quality criterion based on the environmental parameter and designated use to calculate violation rates for each Chesapeake Bay Program assessment segment. The result is a file for each Chesapeake Bay Program segment-designated use combination. (Note: This procedure of implementing different criteria over space for a segment that bridges more than one salinity zone reflects previous documentation in U.S. EPA 2007, Chapter II: Refinements to Chesapeake Bay Water Quality Criteria Assessment Methodology, "Step-4 - Pointwise Compliance" (pp. 17-18) and that "the only requirement (of the assessment) is that the final attainment determination be "yes" or "no" for each interpolator cell." This procedure assures that salinity-variable criteria (e.g., 30-day mean $=5.5 \mathrm{mg} \mathrm{O} / 2 / \mathrm{L}$ where salinity $0-0.5 \mathrm{ppt}$, and $=5.0 \mathrm{mg} \mathrm{O}_{2} / \mathrm{L}$ where salinity $>0.5 \mathrm{ppt}$ in Open Water Designated Use) are appropriately applied based on measured salinities during the assessment period. The Chesapeake Bay Program segmentation boundaries (e.g., XXXTF= "Tidal Fresh", $\mathrm{XXOH}=$ "oligohaline") are not used as the salinity determinant because they are based on historical salinity patterns and would not accurately depict salinity conditions present during individual assessment periods.

\section{STEP 2.5. Water Quality Criteria Assessment, Attainment and Violations}

Output files contain a row for each month of the assessment period (2004 - 2006), and each row contains the following columns:

"failed volume," "assessed volume," "total volume," and "fraction failed" (calculated as failed volume/assessed volume).

A final program takes the accumulated violation rates for each segment-designated use assessment and creates a cumulative frequency distribution (CFD) curve.

Criteria violation results of the assessment CFD (i.e., non-attainment) are compared with a standard reference or "bioreference" CFD curve, which represents an "allowable" amount of criteria violation that can still represent a healthy habitat. For further 
details with illustrations of the CFD development and comparisons procedure, refer to Chapter vi. Recommended Implementation Procedures in Ambient Water Quality Criteria for Dissolved Oxygen, Water Clarity and Chlorophyll a for the Chesapeake Bay and Its Tidal Tributaries (Regional Criteria Guidance) (U.S.EPA 2003). A review of the procedure is provided below.

\section{PLOTTING A BIOREFERENCE CURVE}

A biological reference curve of acceptable violation rates is generated using a cumulative frequency distribution (CFD) of violation rates for "healthy" designated uses. The violation rates are sorted in ascending order, ranked in descending order, and graphed on a quantile plot:

- Violation rates are plotted on the $\mathrm{x}$ axis, with plotting position on the $\mathrm{y}$ axis.

- Plotting position represents the probability, $\mathrm{i} / \mathrm{n}$, of being less than or equal to a given violation rate, or $\mathrm{x}$, and is plotted on the $\mathrm{y}$ axis as a function of rank, or "i", and sample size, or " $n$ ".

- The $\mathrm{x}$ axis is labeled "space" because the violation rate represents the fraction of volume that is in violation.

- The y axis is labeled as "time" because "probability" represents the probable amount of time that a given violation rate will be observed.

- The Chesapeake Bay Program currently uses the Wiebull plotting position to plot the cumulative distribution function. The Wiebull equation for calculating probability, $y$, for each violation rate with rank " $i$ " is:

- $y=i /(n+1) ; i=r a n k$

In order to generate a graph of the CFD:

- $\mathrm{X}_{1}, \mathrm{x}_{2}, \mathrm{x}_{3}, \ldots \mathrm{x}_{\mathrm{n}}=$ violation rates provided herein, sorted in ascending order, with rank (i) assigned in descending order

- $y_{\mathrm{i}}=\mathrm{i} /(\mathrm{n}+\mathrm{l})$

- After plotting the data's violation rates and probabilities, two additional points should be added to the distribution in order to complete the CFD curve:

- Insert $\left(\mathrm{x}_{0}, \mathrm{y}_{0}\right)=(0,1)$ before the first data point

- Insert $\left(x_{n+1}, y_{n+1}\right)=(1,0)$ after the last data point

\section{LITERATURE CITED}

Bahner, L. 2001. The Chesapeake Bay and Tidal Tributary Volumetric Interpolator, VOL3D, Version 4.0. National Oceanic and Atmospheric Administration, Chesapeake Bay Office. http://www.chesapeakebay.net/cims/interpolator.htm

U. S. Environmental Protection Agency. 2003. Ambient Water Quality Criteria for Dissolved Oxygen, Water Clarity and Chlorophyll a for the Chesapeake Bay and Its Tidal Tributaries. April 2003. EPA 903-R-03-002. Region III Chesapeake Bay Program Office, Annapolis, MD.

U.S. Environmental Protection Agency. 2007. Ambient Water Quality Criteria for Dissolved Oxygen, Wlater Clarity and Chlorophyll a for the Chesapeake Bay and Its Tidal Tributaries 2007 Addendum, July 2007. EPA 903-R-07-003 Region III Chesapeake Bay Program Office, Annapolis, MD. 21403. 
appendix

\section{Stations Involved in the 2004-2006 303d Listing Assessment for 2008}

Table B-1. Stations involved in the 2004-2006 303d listing assessment for 2008.

\author{
STATION,UTM_X,UTM_Y \\ 001.332429 .4228770 \\ [ ] J04,385086,40836 I ] \\ I I J09,371365,4089082 \\ 11 J16,352877,4106857 \\ $11 \mathrm{~J} 20,333076,4131339$ \\ $11 \mathrm{~J} 24,323799,4129435$ \\ $11 \mathrm{~J} 29.372088 .4086261$ \\ $11 \mathrm{M} 03,401227,4087648$ \\ $11 \mathrm{M} 08,385305,4122864$ \\ $11 \mathrm{M} 12,396751,4128024$ \\ I I M16,391726.415007 ] \\ 11M21,408521,4179151 \\ $11 \mathrm{M} 25.440944 .4199881$ \\ 1 I R02.368119.4167692 \\ 11 R08.359773.4174837 \\ I IR13.355438.4180790 \\ I IR19.343916.4194977 \\ 1 IR23.313470.4224856 \\ I IR28.368710.4168820 \\ I I YOI .362419,4125841 \\ 1] Y07,357536,4129365 \\ IIY12.352900.4139869 \\ 1 IY 16,342801.4150723 \\ $11 Y 20,326135,4174280$ \\ $11 Y 24,327153.4159761$ \\ II Y28.347570,4145278 \\ 12J02.333875,4124563 \\ 12J07.381671.4084565 \\ 12J13.369573,4086753 \\ 12J 18.346578.41। 8304 \\ $12 J 23.365039 .4095140$ \\ 12J28,357036.4101494 \\ 12M01.408735.4193275 \\ 12M05,385535,4149922 \\ I2M10.386931,4095357 \\ $12 \mathrm{M} 50,410360,4105475$ \\ I2M54,385679,4097040 \\ $12 \mathrm{M} 58.405548 .4181450$ \\ 12M63,373122.4154180 \\ I2R04,338172.420619] \\ I2R08.358718.4179540 \\ 12R13,381556.4160738 \\ I2R18,366984.4165076 \\ $12 R 23,363648.4172578$ \\ I2R5I.366814.4163862
}

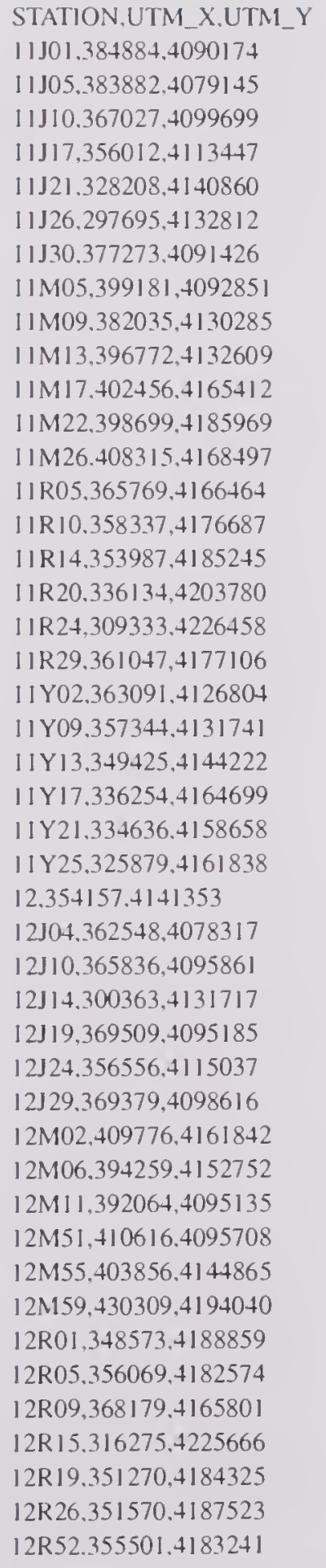

STATION.UTM X.UTM Y

] ] J02,378244.4095294

I I J06,387988,4077170

1 IJ11,360716.4094905

1]J18,356104.4114426

1 ] J22.331320.4122437

$11 \mathrm{~J} 27,321661,4130807$

$11 \mathrm{M} 01,412946.4104658$

1 I M06.390360.4108356

$11 \mathrm{M} 10.379684 .4134839$

$11 \mathrm{M} 14,408106,4144850$

$11 \mathrm{M} 19.386402 .4171288$

$11 \mathrm{M} 23.421816 .4188701$

$11 \mathrm{M} 27,394095,4094153$

1)R06.364362,4165318

I IRII,357392,4177416

IIR 15.350294.4184286

1 IR21,332662,4207607

1 IR25.306676.422922 I

I IR30,321683,4218631

II Y04.360281.4126313

$11 Y 10.356379 .4131943$

$11 Y 14,349373,414+445$

IIY $18,336177.4164605$

$11 Y 22.331819,4158177$

$11 Y 26.346401 .4146943$

$129,370233,4154327$

12J05.365478.4099740

$12 \mathrm{J11.358558.4103051}$

$12 \mathrm{~J} 16.374202 .4090672$

12J20.315601,4130865

12J26, 377346.4094970

$12 J 50.358181 .4102588$

12M03.393520.4189833

$12 \mathrm{M} 07,424142,4170262$

$12 \mathrm{M} 12,405266.4143616$

$12 M 52.401836 .4116605$

$12 \mathrm{M} 56,394538,4161032$

$12 \mathrm{M} 60,405586.4081623$

I2R02.357607.4182571

I2R06.360703.4169431

I 2R 10.305284,4234599

I2R I6.356829.4181047

12R21,357887,4182198

I 2R27.356876.4177033

12Y01.369288.4119164

\begin{abstract}
STATION,UTM_X,UTM_Y
I ] J03,380998.4090425

1 ] J08,375851,4089230

11J14,357043.4100670

1]J19,356282,4116665

I ] J23,329429.4121882

I ] J28,342192,411760 1

$11 \mathrm{M} 02.404083,4087758$

$11 \mathrm{M} 07,401559,4115322$

$11 \mathrm{M} 11,371533,4136265$

$11 M 15.413814 .4145848$

1 ] M20,413374,4178091

IIM24.426484.4192946

I IR01,372854.4163934

11R07,361884,4168819

I IRI2,358075.4178093

IIR17,347211,4188227

I IR22,315369,4224203

1 I R26.334668.4204531

I IR31.364549.4164706

1 I Y06,361003,4129068

$11 Y 11.356647,4135524$

$11 Y 15,346502,4145029$

II Y 19,328309,4173283

$11 Y 23.328370 .4157578$

$11 Y 27.347570 .4145278$

1 2J01.383101,4085048

$12 \mathrm{~J} 06.363363 .4101423$

$12 J 12.364951,4081518$

1 2J17,380489,4088702

12J22.308931,4130099

I 2J27.340700,41 19303

12J51.331988.4138487

12M04.409256.4112239

12M08.408021.4116089

$12 \mathrm{M} 13.388016,4124145$

I 2 M53,399754.4123033

12M57.408774,4174630

12M62,371283,4137416

12R03,356951,4182406

I2R07,336923,419943]

12R11,346493.4191397

I $2 \mathrm{R} 17.38$ I 183.4164083

12R22,363586,4174749

12R50.371239.4173901

$12 \mathrm{Y0}, 361+74,4127273$
\end{abstract}


$12 Y 03.347903 .4143916$ $12 Y 07.366+04.4124014$ $12 Y 12.364919 .4123685$ $12 Y 16.36+569,4125765$ 12Y20.354080,4138659 $12 Y 50.373193 .4124020$ 13J01.371864.4089215 13J06.326134.4124003 $13 \mathrm{~J} 10.357820 .4100162$ $13 \mathrm{~J} 16.3+4731,4116590$ $13 \mathrm{~J} 20.352809 .4114632$

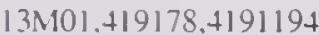
$13 M 05.403989 .4178983$ $13 \mathrm{M} 110.416700+4165851$ $13 \mathrm{M} 14.40168+.4108566$ 13R03.326246, 4213702 13R08.373787,4165129 13R12.345718.4189617 13R16.363736.4165905 13R21.372805.4164784 $13 Y 01.347639 .4145194$ $13 Y 05.336033 .4159330$ $13 Y 09.362918 .4128224$ $13 Y 15.342473 .4152260$ $13 Y 19.362071+126762$ $13 Y 24.347034 .4147596$ I3Y28.362930.4128983 I AAUA004.26.29+171. 4256178 IACOA001.\$.371078. $\$ 204953$ IACUTO00.58.380964.4200362 IAFOU000.19.322226.4301101 IAHACO00.96.383574.4198+14 IALIF000.19.319656.4286947 IALOG001.20.364727.4206164 IAMIAOO04.08.324217.42298.49 IAMONO02.60.327+77.4235515 IANOM1007.79.349141.4215718 IAOCC006.99, 303224. 4284377 IAPOH002.76.310660.4283722 IAPOTO40.80.328860.4233805 IAPOTO41.95.328397.4235329 1APOTOS0.29.299399. 4264955 IASPNO00.08.378093.4199326 I AWES000.41.363387.4210260 1 AWLLO02.21.319886.4246290 I AYEO000.92.365313.4211290 2-BLY000.65.2997+6.4129267 2-CHK015.50.331924.4138404 2DAPP001.91.295841,4131825 2DSFTO01.18.289174.4129111 2-HOF000. $\$ 1,374870,4083960$ 2-JMS007.83.374332.4087735 2-JMS021.26,358213.4102625 2-JMSO49.00.331863.4120763 2-JMS069.08.311660.4130270 2-JMS074. 4.30296 .3 .4132363 2-JMS099.30.288286.+1 42259 2-M1ICO00.03.345285.4120131 2-PAR000.77.383762.4073440 2-PGN000.80.359708.4095972 2-PGN004.57.355\$05.4094240 2-PGN008.42.352010.4096905 2-UCK001.23.323578.4122658 2-WWK003.20.360896.4108595 $32.355055 .409+181$

3-CRR000.23,368907,4167865 3-HOKOO2.74.335485.4197499 3-MLLO01.31.374227.4160685 3-RPP007.03.376681.4165415 3-RPP019.S0.363048.4174028 3-RPP0 $40.89 .3+1807.4197782$
$12 Y 04.358487 .4132732$ $12 Y 08.3+9722.41+2221$ I2Y $13,355505.4133638$ $12 Y 17.356100 .4134184$ $12 Y 21.369916 .41228+1$ $12 Y 51.3631+1.4127084$ 13J02.366360.4097666 13J07,325862.4123332 $13 J 11.325251 .4123889$ $13 J 17.353021 .4112633$ $13 \mathrm{~J} 21,371166.4090850$ 13M102.387927.4172675 13M106.430545.418609 $13 \mathrm{M} 11 .+32827.4196534$ 13M15.404099.4138941 13R04.365894.4165269 13R09.344053,4193717 13R13.363273.4168836 13R 17,377456.4160510 13R22.358895.4180498 $13 Y 02,355822,4133603$ $13 Y 06.3687+9.4122148$ $13 Y 11.351738 .4138515$ $13 Y 16.340652 .4153119$ $13 Y 20.36778+4123108$ $13 Y 25.352660 .41+6795$ $15,353572.4129188$

$1 \mathrm{ABOM} 1000.46 .361251 .4217014$ I ACOA002.06.371715.4204176 I ADOU000.60.3155+1.4285375 I AGAD000.77,358568.4219508 IAHAM 1000.96 .361839 .4208838 I ALIFO01.09.3191+4.4288068 I ALOWO04.77.354857.4217865 1 AMAW001.28.308325.4270249 1 ANEA000. $40.303+60.427+805$ I AOCCO02.47,306593,4279202 1 APOH000.21,313983,4281771 1APOM002.41.296607.4246936 1 APOTO41.55.328628.4234766 1 APOT042.01.328497.4235450 IAPRE001.58.375+58.420109? I AUMCO00.96.321083.4242991 I AWES001.00.362722,4209838 IAX'DW000.08.359594,4218429 2-APP001.53.296+19.4131891 2CCHK002.40.333212.4126091 2-CHK023.64.328494.4141696 2-DECO00.58.383363.4069224 2-EL1003.98.381324.4081793 2-IND000.98.389897.4076063 2-JMS0I 2.79.368+1 1.4093875 2-JMS025.74.351588.4103152 2-JMS050.57.329334.4121196 2-JMS070. $\$ .309009 .4131+40$ 2-JMS077.70.298836.4132820 2-JMIS 104.16.285959,4147513 2-NAN000.00,369794.4086031 2-PAR001.77.382519.4074575 2-PGN001.19.359035.4095641 2.PGN005.46.354865.4094840 2-POW000.60.342253.4121160 2-WBE003.58.375812.4076937 2-WWK003.98,360602.4109706 35.281854 .4155933

3-CTM000.63,371248.4173873 3-HOK003.61.33\$159.4197285 3-MYE000.77.369169,4172488 3-RPP011.58.369683.4164364 3-RPP027.13.355515.4183229 3-RPP0+2.12.339882.4198504
$12 Y 05.352816 .4137062$ $12 Y 10.3575+4.4130728$ $12 Y 14.339717 .4163580$ $12 Y 18.353494,4139214$ $12 Y 22.334575,4160901$ $12 Y 52.326533 .4160948$ $13 \mathrm{~J} 04.377311 .4088797$ 13J08.356303.4108389 $13 J 14.348936 .4119193$ 13J 18.363950 .4102485 $13 \mathrm{~J} 23.370050 .4090455$ $13 \mathrm{M} 03.408+69.4093586$ $13 M 07.403587 .4191220$ $13 M 12.391321 .4108551$ 13R01.375597.4162708 13R05.344234.4193818 13R 10.366396 .4178555 13R1 +.334998 .4204036$ 13R19.369745.4167979 13R24.342202.4198687 $13 Y 03.355996 .4132518$ $13 Y 07.357327 .4129238$ $13 Y 12.352374 .4139699$ $13 Y 17.340937 .4161931$ $13 Y 22.368683 .+121850$ $13 Y 26.339953 .4156295$ 19.371950 .4115770 I ACHOOO1 .57.297049.4264807 IACOA00-4.14,369820,42021 H IADOU001. $40.31+6899.4286542$ I AGLE001 .50 .368393 .4205509 1AHUTO00.01.3217.40.4295553 1ALIS002.00.388+18.419+214 I AMAOO00.42.327977. 4230477 I AMON000.96.327987.4233222 IANEA000.57,303460.4274805 IAOCCO04.52.305326.4281913 IAPOHOO1.56.312384.4282218 IAPOTO00.00.386637.420-4505 I APOTO41 .65,328608, +234936 I APOTO $42.03 .328+24.4235452$ IAQUA002.15.299611,4269685 I AUM1C002.30.319481.4242280 IAWLLL000.94.320052.42\$417 I AXILDO00.15,354357.4221173 2-APP009.52.288987.4125505 2-CHKO01 27.333288.412461 9 2CJMS036 $\$ 3.349469+116398$ 2-DEP000.26.36+477. $\$ 105050$ 2-GOR000.35.333898.4126316 2-JMISO02. 14.380597,4095616 2-JMSOl +.24.366977.4095460 2-JMS027.31,353262.4110620 2-JMS064.52.315488.4128255 2-JM1S071.56.307028.4129956 2-JMIS087.01.296I 40.4137110 2-JMS109.39.286048.4155684 2-NAN019.1 +.358661 .4067106$ 2-PGN000.00.360272.4097165 2-PGN002.58.357036.4095863 2-PGN006.65.353359.4094847 2-SBE001.53.384814.4076792 2-WL,Y002.03,386308,4090436 2-XQW000.69.289451.4137788 3-BRDO00.62.383388.4157650 3-HOK000.15.337018.4198921 3-LAN002.81.358359,4185514 3-OCCO01.85.330044.4211139 3-RPP0I 3.42.366825.416383] 3-RPP028.20.353232.4182287 3-RPP045.21.335951.4201546
$12 Y 06.353399 .4134936$ $12 Y 11.3+2+9.4151126$ $12 Y 15.342074 .4159625$ $12 Y 19.360933 .4129972$ $12 Y 23.3558+6.413+379$ 13.363725 .4128750 1 3J05.358530.4104593 13J09,356704.4107962 $13 J 15.381042 .4091999$ $13 \mathrm{~J} 19.379036 .4088121$ $1.3 \mathrm{~J} 24.352987 .4116203$ $13 \mathrm{M04.403804.4106992}$ 13M109.399175.4116862 $13 M 13.392173 .4187616$ 13R02.375215.4164139 13R06.362204.4175076 I3R I 1.350199.4185866 13R 15.359430.4174611 13R20.321068.4218989 13R25.363120.4168766 $13 Y 04.357634 .4132711$ $13 Y 08.356584 .4133882$ $13 Y 13.354202 .4134097$ $13 Y 18.327987 .4156534$ $13 Y 23.370640 .4121957$ 13 Y 27.346298 .4144854 1AAUA003.71.29+393.4255383 I ACHO003.65.29411 2.4266156 I ACOCO00.42.373260.4204208 1 ADOU002.01.31 $1+781,4286996$ I AGLEO01.76.368034.4204784 I AHUTO01 .72 .319410 .4296506 1 AL.1S004.20.385580.4195271 I AMIAO001.36.326683,4231369 I AMONO01.91.327798.4234583 I ANOM005.99.347993.4218267 I AOCC006.64.303729.4284083 I APOH002.32,311316.4283530 I APOT035.00.339535.4225523 I APOTO41.80.328504.4235154 I APOT0 42.72 .328360 .4235897 I AQUA002.38.299246.4269808 I AUMICOO4.43.319838.4239783 I AWLL.001.30.320013,4245454 1 AYEO000.65.365901.4209979 2-BENO01. +2.368193 .4080723$ 2-CHK002.17.333519.4125734 2-CLG000.23.349687.4121280 2-DSC003.19.332348.4140921 2-GOR000.42.334075,4126537 2-JMS006.70.374985.4090059 2-JMS015.70.366809.4098623 2-JMSO-40.93.342604.4117341 2-JMS066. $88.31+358 .+131632$ 2-JMS073.08.305386.41328I6 2-JMS087.11.295946.4137122 2-JOG000.62.360876.4095527 2-PAR000.12.38+341.4073277 2-PGN000.76.359256.4096578 2-PGN003.57.355670,40955I6 2-PGN007. 4.352981 .4095871 2-SGL001.00.360456.4067607 2-IVWK000.95.362876.4105498 $30.309637,+131426$

3-CRC000.15.334578.4197167 3-HOK000.74.336555.4198261 3-LIT000.85,366056.41791.40 3-PISO00.12,339625.4196605 3-RPP014.38.365692.416637। 3-RPP035.14.345177.4189616 3-RPP060.63.32+368.4219682 
3-RPP067.00.320361. 4223860 3-TOT005.11.348728,4198705 $752 A .346100 .4112363$

7-BRK004.14.375569.4106430 7-CHE003.49.410480.4105725 7-CHE016.05.399854,4123004 7-CHE025.76.376259.4113531 7-CHE038.32.412691.4159275 7-CHE048.79,389592.4179239 7-COCO00.06.386736.4186454 7-COC000.92.387410.4187.558 7-CSX001 .55,432265.4179838 7-EBLO00.01. 404331.4082838 7.EST005.56,379462.4144063 7-EST006.91.379155.4145267 7-HAH002.96.384656.4136541 7-HRP001.15.384656,4136541 7-INN001.06,386080.4184450 7-LNCO00.68.411015.4080454 7-MESO01.34.439853.4195280 7-MJB004.00.381722,4133369 7-NSSO01.62.416840.4148332 7-OCB000.18,433619.4173971 7-OCN004.56.432524.4174183 7-ONB000.56.434153.4174596 7-PKS008.53.430317.4194030 7-PNK010.41.373127.4154176 7.PUNO00.47.424630.4169872 7-SEN001.35,369671.4131466 7-THF000.62.434933.4185697 7-WAR004.26.370478.4139851 7-WESO02.58,400561.4080138 7-XAN000.17,387774.4187007 7-XDN000.27.373648.4142728 8-MPN017.45.332556.4169260 8-MPN039.10.314787.41841.37 8-PMK026.98.326537.4160938 8-PMK048.80.311541,4171014 8-YRK001.12.373185.4123996 8-YRK009.39.363157.4127082 ANA0082,331574,4311772 ANA 1 1.329227.4305746 ANA24.325364.4303.302 APP001.83,295810.4131789 AQU0037.

CB2.1.411823.4366119 CB3.3C.382253.4317113 CB+.IE.380969.4297.307 CB 4.2W,369343,427828I CB 4.4.382750.4252514 CB5.3,397329,4196671 CB6.1,397396.4160791 CB7.1,412737.4171156 CB7.2E 409322.4141018 CB7.4N.411151,4102258 CHE019.38.376475.4119877 CHK015.12.331823,4137970 CHO0490.

COR 1 1.369341,417233 COR7,373384,4178324 CYP2.356498.4092680 EBL002.54.405160.4079376 EE3.0.411113.4237754 EE3 4.430437.4195954 EL12,380690,4082660 ET2.1.\$29838.\$375370 ET4.1,420212.4344230 ET5.2.407846.4270714 ET8.1.428467.4221862 FOCRE,295511.4137654 FOR_4.307247.4229208
3-RPPI04.47,288963,4236940 3-URB001 $00,361155,4165931$ 765.302741 .4273068

7-BRN000.23.386558.4149956 7-CHE004.52.410536.4095924 7-CHE018.14.385697,4097079 7-CHE027.61.403786.41\$460 7-CHE0 40.53.391319,4165601 7-CHE050.87.405530.4181417 7-COC000.86,387266,4187\$49 7-COC000.95.387422.4187589 7-CTCOOI.98.436964.419.4453 7-EBL001.15.404314.4081389 7-ESTO06.33,379845,4145025 7-EST007.06.379086.4145400 7-HKCO00.15.386961,41496.30 7-HUG001.24.41+317.41+1554 7-KNS000.40.410434,4126671 7-LOB001.79.405381.4077063 7-MES006.92.445869.4192957 7-MLF002.40.384756.4150243 7-NWB000.34.380322,4106137 7-OCH003.82.422522.4156417 7-OCN004.96.433358.4174109 7-OPC001.68.411815.4122598 7.PNKOOO 50.384557 .4155038 7-PNK014.33,367843,4155429 7-PUNO02.12.427134.4168967 7-SWB001.53,380468,4103652 7-THG000.36.412878.4136123 7-WAR005.77,368149,4140658 7-WET000.60.370359.4129553 7-XAN000.36,388059,4187099 7-XDQ000.27,380211.4145347 8-MPN01 7.46.332567.4169078 8-PMK006.17.335019.4154703 8-PMK028.43.324933.4161564 8-PMK056.87,307483.4173202 8-YRK004.79.367623.4121449 8-YRK016.88.355361,4135297 ANA01.331670,4309488 ANA $1.328633,4305019$ ANA29.324519.4302148 APPO05.55,291190,4131674 BBY002.88.407532.408.3505

CB2.2.398780.4355918 CB3.3E. 383418.4317836 CB4.IW,373004,4297091 CB 4.3 C. 374994.4268540 CB5.1.386968.4241940 CB5.4.396587.4184289 CB6.2.397772.4149505 CB7.1N.414166.4181313 CB7.3.400035.4108+23 CB8.1.396093.4095002 CHK001.47.334058.4124726 CHK023.96.328514.41+1669 CHP,348307.4111102 COR $3.370468,4181758$ COR9.371191, 4172745 EBB01,389035.4077414 EE1.1,391609,4304585 EE3.1,414660.4228468 EE3.5.425661,4183574 ERP_RIC, 38\$450.4077457 ET2.2.424761.4368943 ET4.2,394661,4316568 ET6.1, $437567 .+265248$ ET9 $1.429117,4212609$ FOCRL_AG.289043.4138148 FRG0002.378783.4352698
3-RPP107.91,285821,4240552 3-WHS000.89,368117.4163379 7-BBY002 88.407537.4084005 7-BWN000.45,405580.4081622 7.CHE008.90.400213,4103090 7-CHE019.79.409521.4131780 7-CHE033.65.406763.4152802 7-CHE046.24.408823,4174667 7-CHE055.94,399219,4193155 7-COC000.88.387473.4187505 7-COCO01.61.387408,4188526 7-DEP001.38.434050,4180587 7 -EBLO02.54,405159,4079377 7-EST006.41,379742.4145095 7-FER000.92,370130,4152832 7-HKCO00.18.386956,4149636 7-HUN001 $88,438116,4182039$ 7-LKN001.19.409794.4082039 7-LTH000.14.432103.4173642 7-MIL002.00,384069,4I83739 7-MUD002.29, 443000,4190304 7-NWB000.38.380192.4106507 7-OCNO0I.92.429087,4175978 7-ONBO00.19,433549,4174366 7-OSBO00.13.433132.4173695 7-PNKO0I 26.384243.4153636 7-POCO01.76, $\$ 44549.4203301$ 7-OUE001 .23,380963,4149699 7-TAW000.22.418386.4157368 7-WAR000.88,374244,4136103 7-WES000.62,401362,4083056 7-WHY000.38.384586.4188614 7-XBO001.30,405332,4074845 8-FEL000.19,359370.4126447 8-MPN021 .07,331050,4173368 8-PMK017.67,331779.4159530 8-PMK039.74,315366,4164047 8-QEN002.47,353684.4129122 8-YRK004.80.368401.4123792 8-YRK021.16,351693,4140831 ANA05,330420,4308527 ANA $19,326758,4304276$ ANA 30.332018 .4311226 APP007.58,290915.4128.466 BXK0031.460479.421 4956 CB3.1,393173.4345077 CB3.3W.379813,4318075 CB4.2C. 376622.4278319 CB4.3E.378916.4268479 CB5.1W.379767,4242784 CB5.4W.386042,4185908 CB6.3.397375.4141157 CB7.1S,406584.4159881 CB7.3E 406515.4120769 CB8.1 E.407851,4089534 CHK006.14.333694.4131I69 CHO0367,

COAN5,367507.4206156

COR5,365898,4179190 CR8,329.492.4131109 EBE $1.385059,4077977$ EE2.1.389081.4278722 EE3.2.418794.4204010 ELD01.3815+1.4080783 ETI 1 $417720+4381039$ ET2.3.422657.4373588 ET5 0.431956 .4316775 ET6. $2,422828,4243182$ FOCR27A.290992.4139076 FOR_1.282966.4240883 FRG0018.378928.4354684
3-RPPI10.57,283925, $\$ 244211$ 5BWNC010.02.404533.4072552 7-BLB004.63, $\$ 46343,4203032$ 7-CCHOOO.43.409597.4124691 7-CHE012.06,401819,4116455 7-CHE020.80.389219.4123827 7-CHE037.88.394538.4161031 7-CHE047.16,425565,4176076 7-CHSO00.84.374251,411621। 7-COCO00.89.387448.4187517 7-CRY000.59,411426.4081898 7-DRN003.40,358389.4161011 7-ESTO02.75,3806+1, 4140383 7-EST006.68,379536,4145280 7-GWR008.89,375180,4192422 7-HLD002.67.446513.4197976 7-IND002.26,380990,4173449 7-LKN002.77.410016.4079663 7-LYN000.03,402732,4085142 7-MIL004.00,381202.4184759 7-NEW001.92.378598.4099666 7-OCB000.10.433477.4173969 7-OCN003.28.430889.4174884 7-ONB000.20.433602.4174369 7-OSB000.25.433342.4173638 7-PNK005.35.378919.4154933 7-POQ004.12.371824,4111076 7-SENO00.19.371294,4131339 7-THA000.76.399755.4078069 7-WAR002.88.371272.4137404 7-WESO01 .68.401294,4081393 7-WIL001 .50.368768.4136705 7-XDB000.08,382365,4180520 8-KNG004.46,357578,4126404 8-MPN024.84,3261 88,4173993 8-PMK023.12,326164,4156595 8-PMK044.64,313427,4167601 8-SRW000.35.368538,4124653 8-YRK005.67.366800.4122886 8-YRK027.00.345614,4148057 ANA08.329841. 4307368 ANA21,326043,4302361 APP001.53.296949.4131991 APP01 1.04,288246,4123970 CB 1.1.407087.4377829 CB3.2,387I 40.4335727 CB4.1C.378499.4298300 CB4.2E,378169.4278295 CB4.3W,369911.4268621 CB5.2.392384,4221705 CB5.5.395113,4172286 CB6.4.392849.4121795 CB7.2,404455,4141073 CB7.4.409195,4094882 CCM10069. $\$ 21016.4255255$ CHK008.30,334117,4134513 CHO0417,

COR0056.

COR6.368533,4175274 CYP.356195,4093196 EBL000.01.404330,4082838 EE2.2.385995,4265816 EE3.3.432666,4199634 ELE01.384272.4078834 ET10.1.450335.4215226 ET3.1. 423936.4357851 ET5.1.420824.4295761 ET7.1,430776.4235712 FOCRAPP.289197.4129039 FOR_2.282677,4244III GP1.359159,4095505 
GW 1.374130.4192478

GW6.375133.4192485

HCWF_PIER.374864,4083967

IH3.30+110.4267810

JCI, 360878,4093118

JMS042.92,341843.41 I8873

JMS055.94.323512.4126984

JMS075 04,302135,4131894

JMS 104.16.286040.4147541

JMSMH 20M.358354.4102271

JMSMH_8M1.352893.4104997

JMSOH 26G.342441.4116686

JMSPH_12P(1).383298,4094382

JMSPH_13P(I).376002.4090772

JMSPH_18P(1).381628.4170049

JMSPH_5P.376053.4087673

JMSPH_9P.381693,4092832

KNG01.331387.4306410

LE1 .3.369960.4244663

LE3.1.357659.4180333

LE3.6.386593.4161856

LE4.3.373068.4121782

LE5.3.368701.4094829

LFA01.382889.4085496

LKN002.77.410016.4079664

MDR0028,377197.4352657

MPN001.65.342334.4156035

MPN016.28.333757.4169416

MPN028.86.322012.4176989

NOM0007.376691,4351200

PMK006.16.335150.4154852

PMK023.69.327052.4157986

PMK047.41.31 I I37.417122 I

PMS29.324518.4302117

PMS51.323525.4293226

PNK013.91,368548.4155161

РTB01.323115.4306220

PXT0455.351147.4293900

RET2.4.326093.4247926

RET4.2.341 294.4159764

RIC.364854.4090657

SCAUST.290399.4258089

SCSHORE. 296472.4253724

SMT02.371683,4230150

SMT08.371055.4224610

SMT $12.374363,4224417$

TF1.5,352073,4285982

TF2.2.316395.4284566

TF3.1E.296531.42355I2

TF4.2.321520.4161136

TF5.3.288218.41 42278

TF5.6.323512.4126984

TOT 2.349762.4198971

TRQ0088.413273.4252581

WB 1.399240.4079616

WE4.2,377038.4122598

WIW0089.

WT1.1,393167.4365613

WT5.1.368360.4341015

WT8. 2,367033,4304960

XAK7810.442840.4202056

XBE8396.368039.4222175

XBF5231..

XBF7904.

XCC4530.

XCD3596.

XCD7202..

XCF2621,371683.4230149

XCH8973.408670.4241343

$\mathrm{XCJ} 5200$.

XDB4544.,
GW2.372523.4194345

GW8.379751.4190651

HOK0005,375698,4352726

IH4.310091.4271218

JM 1 S002.55.377473,4095389

JMS043.78.341072.4121641

JMSO62.82.317509.4127379

JMS082.49.300736.4139625

JMS109.62.286771.4156012

JMSMH 23M.353723.41I866I

JMSMH_QC_0.1N(20M).368947.4092187

JMSOH_3IG.329806.4120138

JMSPH_12P(100).383298.4094382

JMSPH_13P(100).376002.4090772

JM1SPH_18P(100),381628.4170049

JMSPH_5P(1).376053.4087673

JMSPH_9P( I ).381693.4092832

KNG02.329525.430725 1

LE1 .4.375738.4241396

LE3.2.363259.4170237

LE3 7.384553.4154548

LE4.3B.369181.4121517

LE5.4.376002.409077।

LFB01.385815.4083370

LYN000.03,402627,4085156

MDR0038.375899.4353341

MPN005 04,341256,4160238

MPN018.70.331870.4170504

MPN031.95.317460.4180097

P1A1.374167.4153268

PMK008.92.335637.41586I2

PMK034.00.321321.4160784

PMS01.317531,4309771

PMS35.323814,4299727

PNK002.52.382214.4151860

PNK018.35.363424,4158873

PWC04.324576.4304707

RET1.1.354868.4261571

RET3.1.339830.4198205

RET4.3.341892.4152809

RICE1,304865,4133290

SCDOBE. 299028.4247597

SCSPILL. 294502,424671 1

SMT04.373908.4227728

SMT09.366841.4225233

TF1.2.347994.4297623

TFI.6,353440.4280160

TF2.3.310717.4275538

TF3.2.308359,4227553

TF4.4.321476.4176991

TF5.4.296949.4131991

THA000.07.399520.4078978

TOT 3.348738.4198734

TRQ01 46,412737.4257964

WBB05.375524.4076831

WE4.3.378116,4115369

WIW0141,439234.4243948

WT2.1.384454,4360187

WT6.1.372437.4326147

WT8.3.366971,4301260

XBD9558.

XBE9300,

XBF6734.373469.4219207

XBF9130.372996.4223562

XCC8346.

$\mathrm{XCD} 3765$.

XCE1407.

XCF9029.373013,4241953

XCI3696.

XCJ6023.

XDB4877.
GW3.373221.4192892

GY10001,396196,4327448

IH $1.309067,4273070$

IH5.304872.4269181

JMS018.23.365742.4101843

JMS048.03.333319.4123129

JMS069.08,311362,4130460

JMIS094.45.292157.4139492

JMSMH_16M.373831.4088013

JMSMH_25M,355353.4111480

JMSOH_13G.331043.4120361

JMSOH_3G.352502.4120758

JMSPH_12P(1 N).383298.4094382

JMSPH_13P(1N).376002.4090772

JMSPH_18P(IN).381628.4170049

JMSPH_5P(100),376053,4087673

JMSPH_9P(100),381693,4092832

LE1.1.360193.4254200

LE2.2.361327.4225505

LE3.3.370000.4172268

LEA 1.350343.4142679

LE5 1.353723.411866।

LE5.5-W.383 I 45.409557 !

LIT_TOT.348805.4199011

MATO0I6.308909.4270769

MNK01 46.436651.4225492

MPN008.12.339310.4163162

MPN021.95.329357.4173031

MTI0015.351613.4289677

PIS0033.327238.4285187

PMK01 2.18.333603,4159929

PMK037.34.316238.4163086

PMS 10.320551.4307974

PMS37,323676,4298959

PNK004.41.380221.4155178

POK0014,444014.4203910

PXT031 1..354038.4276642

RET2.1.301859.4253019

RET3.2.349306.4186290

RET5.1 A.333694.4131169

SBE2.384911.4074949

SCHARB.292080.4259256

SGC0041.366758.4225326

SMT06.372996, 4223562

SMT10.375810.4225146

TF1.3.351 339.42971 28

TF1.7.353648,4271707

TF2.4.302544.4267037

TF3.2A.319860.4220341

TF5.2.284929.4156509

TF5.5.302135.4131894

TOR01.322857.4300088

TOT 4.347298 .4194598

TSK000.23.348286.4142287

WBEI.378796.407834]

WE4.4.385118.4107873

WIW0144.

WT3.1.379310.4351015

WT7.1.369723,4318606

WXT0001.351 1 42.4294357

XBE2100.,

XBF0320.,

XBF6843.374772.4219372

XBF9949.375810.4225146

XCC 9680 .

XCD5599..

XCE2643..

$\mathrm{XCH} 4378,409338.4232794$

$\mathrm{XCl} 4078.423925 .4232127$

XDA0338.

XDB8278.
GW4.373207.419197I

HCWF_FORK.625184.4083702

IH2.307992.4269498

lH6.305256.4268604

JMS032.59.353723,4118661

JMS050.74,329875.4120262

JMS073.37,304687,4133228

JMS099.00.288718.4142030

JMSMH_I A_M.370074.4094759

JMSMH_4M,368947,4092187

JMSOH_22G.350816.4118845

JMSPH_12P.383298.4094382

JMSPH_13P,376002,4090772

JMSPH_18P.381628.4170049

JMSPH 21 P.383125.4095549

JMSPH_5P(1N).376053.4087673

JMSPH_9P(1N),381693.4092832

LE1.2.368014.4248919

LE2.3.381705.4209059

LE3.4,372510,4165995

LE4.2.360117.4128260

LE5.2,358355.410227।

LE5.6.380766.4085121

LKN001.19,409794.4082039

MAT0078.315480.4273237

MOB006.12.376827.4124418

MPNO1 1.97.335469.4164943

MPN024.65,326202.4174627

NFHFP 4.306182 .4134236

PMK001.29,339868,4156069

PMK018.13.329744.4159301

PMK041.30.312568,4166494

PMS21.322842.4304807

PMS $4+323103,4295980$

PNK009.96.374119.4152822

POK0087.442045,4210439

PXT0435.352348.4291193

RET2.2,307375,4247179

RET4.1.334971.4154825

RET5.2,341843,4118873

SBE5,384333,4070127

SCRAVEN,294137.4250252

SMT01,369552.4231904

SMT07.373469,4219207

SMT1 1.374458.422031 1

TF1.4.351454,4292963

TF2.1.321870,4286200

TF3. I B, 304567,4235496

TF3.3.332405.4209585

TF5.2A.286040.4147541

TF5.5A.311362.4130460

TOT_1.354273.4197480

TPB01.328583.4306069

TUK0022.,

WE4.1,380697.4130313

WES001.68.401294.4081393

WIW0198.,

WT4.1.374969.4349233

WT8.1.368570.4310484

WXT0013,350561.4295545

XBE6753.

XBF3534..

XBF6903..

XBG2601.,

XCD0517.,

XCD6674.,

XCF 1336.373908 .4227728

XCH8097,4I2074.4239583

$\mathrm{XCI} 4821.415635,4233632$

XDA6515.,

XDC3807. 
XDE $\$ 587.367132 .4252270$

XEA9461..

XEG0138.

XEG4991..

XEG8519.

XEH8132..

XFB 1839.317182 .4285151

XFB $\$ 408$.

XFG3973.

XFG9210.385759.4297621

XGE0284.367389.4299764

XGE5984..

XGFI 780.366996.4302422

XGG+301.38+626.4307155

XGG5959.393038.4309868

XHF0 $460,378756 .+318542$

XHG6496.398583.4329224

XHH 4822.402236 .4326309

XHH6419.401908.4329334

XJF0588.383342.4355530

XJG2340.390817.4358572

XJG7035.390335.4367578

YRK001.20.373779.4121033

YRK012.78.357470.4129417

YRK031.24.341562.4152366

ZDM0003.369412.4310776
XDJ9007 $\$ 28+2+\$ 259817$ XED0694.353759.4263780 XEG1995..

XEG5627.。

XEG8593..

XE17405.

XFB1986.324071.4285164 $X F D 1283.352507 .4283330$

XFG4620..

XFH2312..

XGE2488.368063.4303862 XGE6281.367272.4310889 XGF5+04.370593.4309383 XGG4898.398663.4307823 XGG6667.

XHF0561.378835.4318640 ХНH3851..

ХHH4916..

XIE5748.3631 $+3 .+346973$

XJF0821.387984.4356005

XJG2718.387666.4359928

XJG7856.393266.4368782

YRK005.40.367276.4123465

YRK015.09.357251.+134595

ZDM0000.369297.4310645
XEA3687.309296.\$270145 XEEI 502.354949 .4265413 XEG2646.

XEG6966.

XEH5622,

XFB0231.315993.4282269

XFB2184.323831.+285612

XFG0809..

XFG5054,

XFH7523.402026, 4294370

XGE3275.366301.4305255

XGE7059.361063.4312343

XGG2084.396507.\$302690

XGG51 15.386669.4308606

XGG8251.391935, $431+323$

XHG0859.393086.4319043

XHH4528.,

XHH+931.

XIH0077.410272.4335782

XJF2675.381393.4359748

XJG $4337,390418,4362370$

XJH2362..

YRK006.77.364805.4123064

YRK023.40.348780.41 $\$ 2550$

ZDMO001.369325.4310755
XEA6046.

XEE3604.355325.426931

XEG3623..

XEG7539.

XEH7912.

XFB0500..

XFB5581.323512.4292014

XFG0965..

XFG9164.393576.4297449

XF11515.

XGE5492.368823.4309363 XGF0681.381515.4300351 XGG3479.395865.4305355 XGG5932.389110.4310075 XGG9992.397896.4317382 XHG1579.395979.4320319 $\mathrm{XHH}+742$.

XHH5046.

XIH3581.410971.\$342271

XJF $\$ 289.383623,+362249$ XJG $\$ 151.392592 .4363098$ XJ11871,.

YRK010.59.361480.4128917 YRK028.58.345373.4150519 ZDM0002.369.352.4310810 
appendix $\mathbf{C}$

\section{A Comparison of Methods for Estimating $\mathrm{K}_{\mathrm{d}}$}

The light attenuation coefficient $\left(\mathrm{K}_{\mathrm{d}}\right)$ is used to assess the Chesapeake Bay water clarity criteria, measured as percent light-through-water (PLW), using the following equation:

$$
\text { PLW }=100 * \exp ^{\left(-K_{d} Z\right)}
$$

where 'exp' is the base of the natural logarithms and ' $\mathrm{Z}$ ' equals the criteria application depth.

$\mathrm{K}_{\mathrm{d}}$ is measured in situ at DATAFLOW calibration stations using LICOR and then related to other measured parameters-turbidity, chlorophyll fluorescence, and salinity - to generate a calibration curve that enables the estimation of $\mathrm{K}_{d}$ at cruisetrack points. The spatially intensive nature of DATAFLOW data support the interpolative analysis used to produce the cumulative frequency diagram applied in criteria assessment. However, $K_{d}$ can be interpolated in two ways. In one method, $K_{d}$ is calculated at each cruisetrack point using the three simultaneously measured parameters, and then it is interpolated. This method is described in Chapter 7 of the 2007 Ambient Water Quality Criteria for Dissolved Oxygen, Water Clarity and Chlorophyll a for the Chesapeake Bay and its Tidal Tributaries - 2007 Addendum (U.S. EPA 2007). The other method calls for first interpolating turbidity, chlorophyll $a$, and salinity and then using the resulting estimates of these parameters to calculate $\mathrm{K}_{\mathrm{d}}$. This method was used by both Virginia Institute of Marine Science (VIMS) and Maryland Department of Natural Resources (MD DNR) for the 2008 water clarity assessment.

The two methods were compared to determine if they produce similar results. Between 100-200 "validation" points were randomly selected and removed from three James River DATAFLOW cruisetracks (Figures C-1, C-2 and C-3). The remaining cruisetrack points were then analyzed using the two methods (i.e.. calculating $\mathrm{K}_{\mathrm{d}}$ from its correlated parameters prior to interpolation versus calculating $\mathrm{K}_{\mathrm{d}}$ after interpolating its correlated parameters). $\mathrm{K}_{d}$ was calculated at each validation point using the turbidity, chlorophyll, and salinity measured at that point. This value was then compared to the estimated $\mathrm{K}_{\mathrm{d}}$ values generated from the two methods.

The following equation (see Chapter IV, Table IV-2 of this document) was used to calculate $\mathrm{K}_{\mathrm{d}}$ :

$$
\begin{aligned}
\mathrm{K}_{\mathrm{d}} & =1.19267+0.2956 * \text { Turbidity }^{(1 / 1.5)}-0.05616 * \text { Salinity }+0.0002746 * \\
& \text { Chlorophyll } a
\end{aligned}
$$




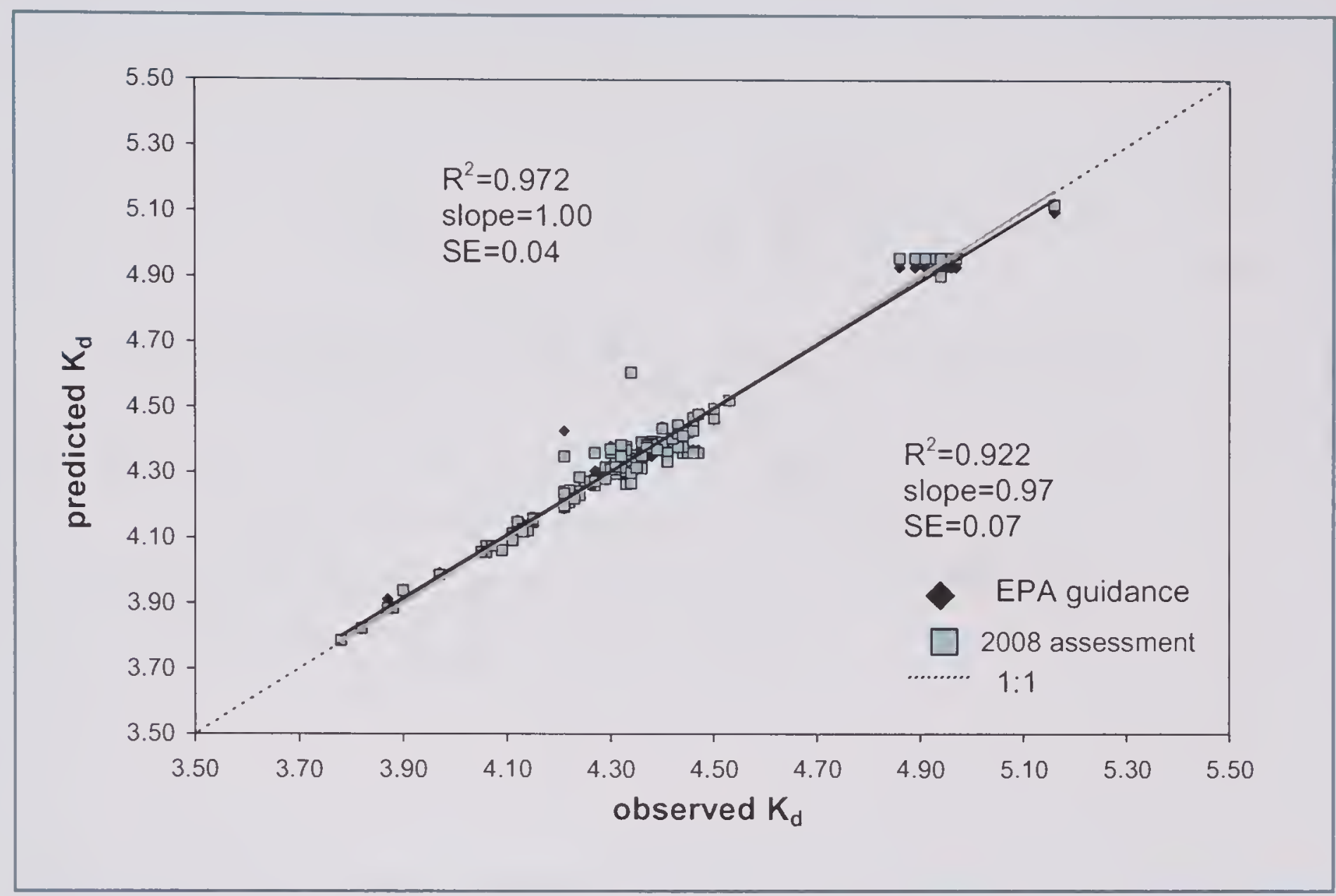

Figure $\mathrm{C}-1$. A comparison of the two $K_{d}$ estimates against values calculated at validation points $(n=133)$ in James River tidal fresh-Lower Chesapeake Bay Program segment (JMSTFL) (4/7/2005 cruise).

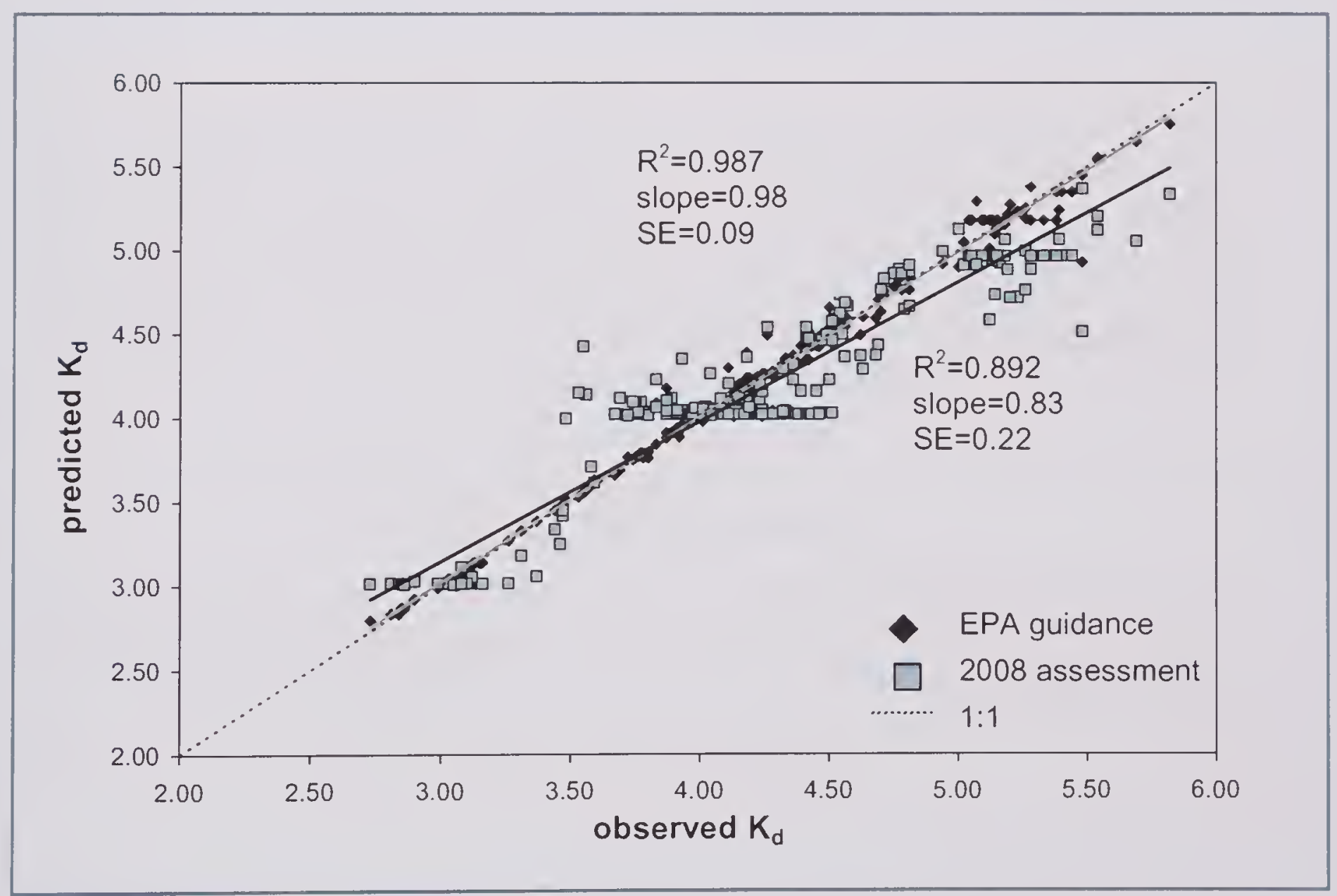

Figure C-2. A comparison of the two $K_{d}$ estimates against values calculated at validation points $(n=200)$ in tidal middle James River Oligohaline Chesapeake Bay Program segment (JMSOH), 5/22/2006 cruise. 


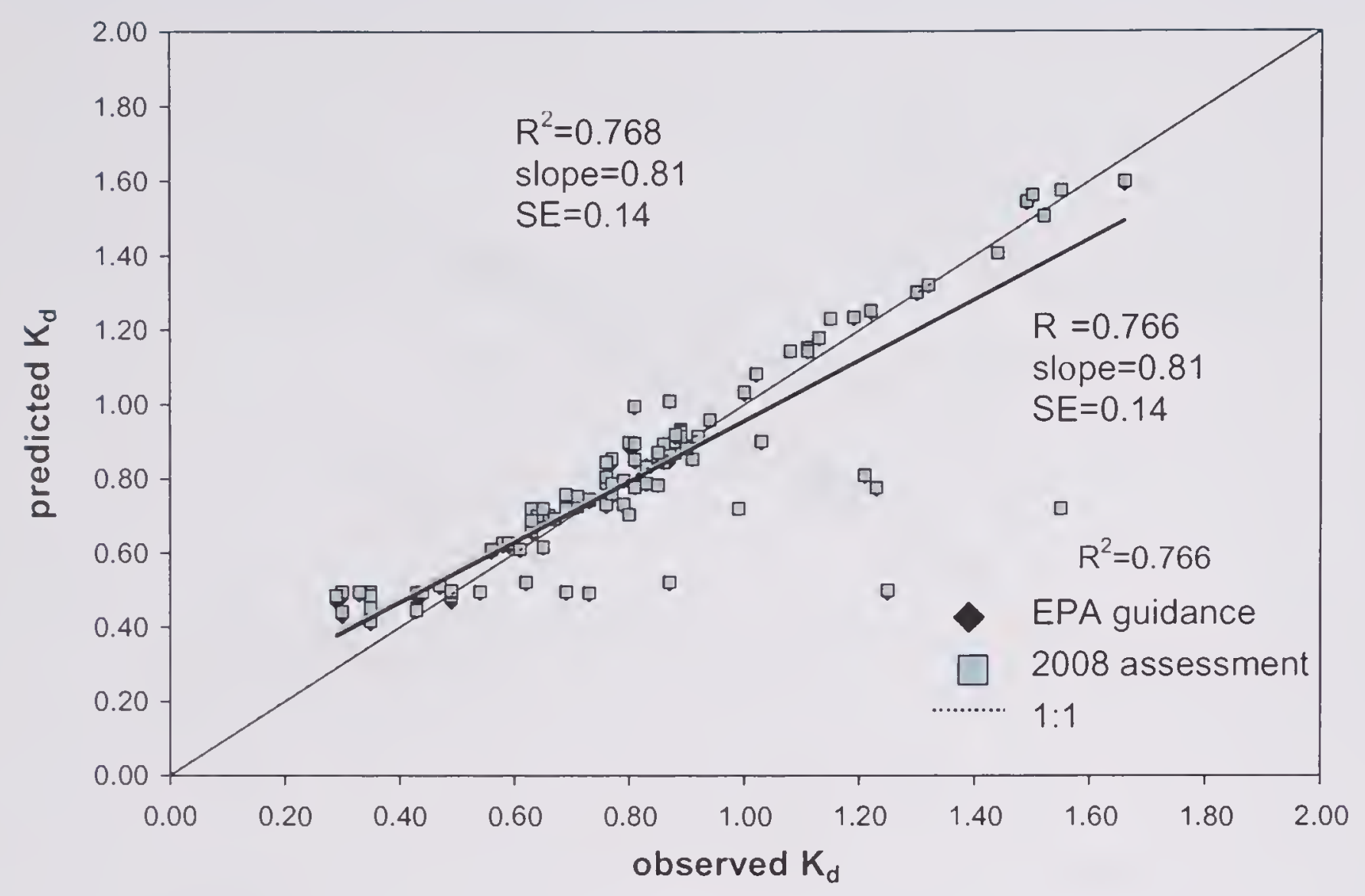

Figure $C-3$. A comparison of the two $K_{d}$ estimates against values calculated at validation points $(n=99)$ in the lower tidal James River Polyhaline Chesapeake Bay Program segment (JMSPH) (9/14/2005 cruise).

At least for the three selected cruisetracks, the two methods produced similar estimates, though there is a suggestion that the method used for the 2008 assessment predicts with less error. The methods come with their own advantages, however. The 2007 U.S. EPA guidance method is faster and easier to do as there are fewer steps involved. The 2008 assessment method is difficult to do without either ArcInfo or Arc Spatial Analyst, but it allows one to visualize spatial patterns, particularly areas of uncertainty, in the individual components of $\mathrm{K}_{\mathrm{d}}$.

\section{LITERATURE CITED}

U.S. Environmental Protection Agency. 2007. Ambient Water Quality Criteria for Dissolved Oxygen, Wlater Clarity and Chlorophyll a for the Chesapeake Bay and Its Tidal Tributaries - 2007 Addendum. EPA 903-R-07-003 Region III Chesapeake Bay Program Office, Annapolis, MD. 21403. 
appendix

\section{Derivation of $\mathrm{K}_{\mathrm{d}}$ Regressions DATAFLOW Report on the Lumping vs. Splitting of Regions for MDDNR DATAFLOW $K_{d}$ vs. Turbidity Regressions and Calibration ${ }^{1}$}

This report addresses a series of questions for Maryland $\mathrm{K}_{\mathrm{d}}$-Turbidity data using a suite of analyses. The questions and simple answers are summarized here. More detailed discussion on the methods and results follow below. The following abbreviations are used throughout this report text:

$\begin{array}{lll}\text { ANCOVA } & =\text { Analysis of covariance (ANCOVA) } \\ \text { Chl or chla } & =\text { chlorophyll } a \text { (ug/L) } \\ \text { Coeff Var } & =\text { Coefficient of Variation } \\ \text { DATAFLOW } & =\text { flow through data collection system for water quality } \\ & \text { monitoring } \\ & =\text { light attenuation coefficient } \\ \mathrm{K}_{\mathrm{d}} & =\text { logarithmic transformation of chlorophyll } a \\ \text { Logchla } & =\text { Maryland Department of Natural Resources } \\ \text { MD DNR } & =\text { root } 1.5 \text { transformation of turbidity } \\ \text { r1_5turb } & =\text { coefficient of determination } \\ \text { R-square } & =\text { root mean square error } \\ \text { Root mse } & =\text { salinity (ppt) } \\ \text { Sal } & =\text { turbidity (ntu) } \\ \text { Turb } & =\text { tributary } \\ \text { Trib } & =\text { Virginia Institute of Marine Science } \\ \text { VIMS } & \end{array}$

'Appendix D is the report by Elgin Perry. Ph.D. 12/27/2006. Notes on Lumping vs Splitting Kd= f(turbidity) calibration. 


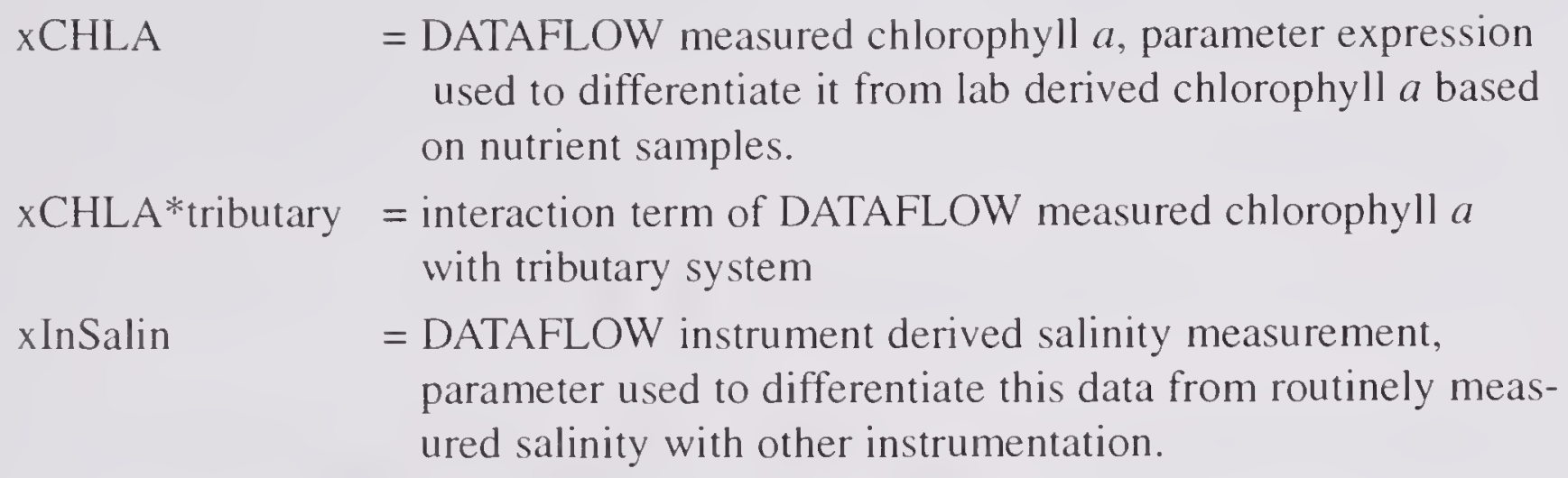

Questions regarding $\mathrm{K}_{\mathrm{d}}$-Turbidity relationships:

1. Does the $\mathbf{1 . 5}$ root transformation that worked well to linearize the $\mathbf{K}_{\mathbf{d}}$ Turbidity relation for VIMS data work well for MD DNR data? Yes.

2. Does one $\mathbf{K}_{\mathbf{d}}$-Turbidity model work for all tributaries? No.

3a. Is chla (chlorophyll $a$ ) an important predictor? Yes, but contribution is less than Turbidity.

3b. Is chla effect same for all tributaries? No.

$3 c$. Is it better to use chla or logchla? Chla

4. Is Salinity a useful predictor? Yes

5. Is there a seasonal effect? Not much

6. Can Tributaries be grouped so that calibration terms are uniform within group? Yes - the 15 tributaries form 6 groups.

The following details provide the supporting analyses for the answers to the questions above:

1. Does the $\mathbf{1 . 5}$ root transformation that worked well to linearize the $K_{d}$ Turbidity relation for VIMS data work well for DNR data? Yes.

To address this question, a series of linear regression analyses were done use root transformations ranging from the 1.1 root to the 2.9 root. $\mathrm{R}$-square and root mean square error for this series are reported (Table D-1) as measures of goodness of fit.

Table D-1. R-square and root mean square error from a series of linear regression models where $\mathrm{K}_{\mathrm{d}}$ is the dependent variable and the independent variables include Tributary, root(turbidity), Tributary*root(turbidity), chlorophyll, Tributary*chlorophyll. The root transform of turbidity ranges from 1.1 to 2.9. Note: "chlorophyll" refers to chlorophyll a measurements. 
Table D-1. Comparison of R-square and Root Mean Square for $K_{d}$ regressions to assist in determining the best root transformation with turbidity.

\begin{tabular}{|c|c|c|}
\hline root & RSquare & RootMSE \\
\hline 1.1 & 0.692513 & 0.777389 \\
\hline 1.2 & 0.694958 & 0.774293 \\
\hline 1.3 & 0.696466 & 0.772377 \\
\hline 1.4 & 0.697318 & 0.771292 \\
\hline 1.5 & 0.697708 & 0.770795 \\
\hline $1.6^{*}$ & 0.697773 & 0.770712 \\
\hline 1.7 & 0.697609 & 0.770921 \\
\hline 1.8 & 0.697286 & 0.771333 \\
\hline 1.9 & 0.696852 & 0.771886 \\
\hline 2.0 & 0.696342 & 0.772534 \\
\hline 2.1 & 0.695784 & 0.773244 \\
\hline 2.2 & 0.695196 & 0.773991 \\
\hline 2.3 & 0.694590 & 0.774759 \\
\hline 2.4 & 0.693978 & 0.775535 \\
\hline 2.5 & 0.693367 & 0.776310 \\
\hline 2.6 & 0.692761 & 0.777076 \\
\hline 2.7 & 0.692165 & 0.777829 \\
\hline 2.8 & 0.691581 & 0.778567 \\
\hline 2.9 & 0.691011 & 0.779286 \\
\hline
\end{tabular}

*Highest r-square and lowest root mean square error are obtained for the 1.6 root of turbidity. This is very nearly matched by the results for the 1.5 root which was optimal for the VIMS data. Thus 1.5 root will be employed for funher work

\section{Does one $\mathbf{K}_{\mathrm{d}}$-Turbidity model work for all tributaries?}

Analysis of covariance (ANCOVA) with an interaction term for Tributaries*turbidity was used to assess the consistency of the turbidity effect over tributaries (Table D-2).

Table D-2. ANCOVA table showing test for consistency of turbidity (turb) effect over tributaries. " $r 1$ 5turb" is the root1.5 transform of turbidity measurements.

\begin{tabular}{lccccc}
\hline Source & DF & Type III SS & Mean Square & F Value & Pr $>$ F \\
\hline tributary & 16 & 19.432 & 1.214 & 2.04 & 0.0087 \\
\hline rl_5turb & 1 & 330.819 & 330.819 & 556.82 & $<.0001$ \\
\hline rl_5turb*tributary & 16 & 65.436 & 4.089 & 6.88 & $<.0001$ \\
\hline
\end{tabular}


The evidence is strong $(\mathrm{p}<0.0001)$ that the coefficient for the turbidity term is not consistent among tributary systems. Thus some splitting of the tributaries into groups should be explored.

3a. Is chla an important predictor? Yes, but contribution is less than turbidity.

To address this question, the ANCOVA model was expanded to include terms for chlorophyll (as measured by DATAFLOW) and tributary*chlorophyll (Table D-3).

Table D-3. ANCOVA table showing test for chlorophyll and consistency of chlorophyll effect over tributaries.

\begin{tabular}{lccccc}
\hline Source & DF & Type III SS & Mean Square & F Value & Pr $>$ F \\
\hline tributary & 16 & 19.290 & 1.205 & 2.39 & 0.0016 \\
\hline rl_5turb & 1 & 197.379 & 197.379 & 391.14 & $<.0001$ \\
\hline rl_5turb*tributary & 16 & 25.554 & 1.597 & 3.17 & $<.0001$ \\
\hline xCHLA & 1 & 14.771 & 14.771 & 29.27 & $<.0001$ \\
\hline xCHLA*tributary & 16 & 33.057 & 2.066 & 4.09 & $<.0001$
\end{tabular}

Both the chlorophyll term $(\mathrm{p}<0.0001)$ and the chlorophyll* Tributary term $(p<0.0001)$ are statistically significant. However, the mean square for turbidity $(\operatorname{msIII}($ turb $)=197.2318735)$ is much greater than the meansquare for chlorophyll $(\operatorname{msIII}(\mathrm{chla})=14.7708689)$. From this we infer that while chlorophyll is an important predictor $(\mathrm{p}<0.0001)$ it is much less important than turbidity.

\section{3b. Is chla effect same for all tributaries? No}

The interaction statistic for chlorophyll and tributary is significant $(p<0.0001)$ and this implies that the association of chlorophyll and $\mathrm{K}_{\mathrm{d}}$ is not uniform over tributaries.

3c. Is it better to use chla or logchla? Chla

Using the above model, the overall $r^{2}($ chla $)=0.739471$ and the overall $r^{2}(\log c h l a)=$ 0.721274 . Thus is appears that the untransformed chla gives better prediction.

\section{Is Salinity a useful predictor? Yes}

Table D-4. ANCOVA table for model expanded to include salinity terms.

Salinity appears to be an important predictor but its effect is not consistent over tributaries.

Table D-4. ANCOVA table for model expanded to include salinity terms.

\begin{tabular}{lccccc}
\hline Source & DF & Type III SS & Mean Square & F Value & Pr $>$ F \\
\hline tributary & 16 & 16.086 & 1.005 & 2.03 & 0.0093 \\
\hline rl_5turb & 1 & 162.130 & 162.130 & 327.82 & $<.0001$ \\
\hline rl_5turb*tributary & 16 & 14.711 & 0.919 & 1.86 & 0.0206 \\
\hline xCHLA & 1 & 9.717 & 9.717 & 19.65 & $<.0001$ \\
\hline xCHLA*tributary & 16 & 21.609 & 1.350 & 2.73 & 0.0003 \\
\hline xInSALINITY & 1 & 0.057 & 0.057 & 0.12 & 0.7339 \\
\hline xInSALINIT*tributary & 16 & 18.498 & 1.156 & 2.34 & 0.0021 \\
\hline
\end{tabular}


5. Is there a seasonal effect? Not much.

To address the seasonal issue, we compare models with and without month terms (Table D-5a,b,c,d).

Table D-5a. Before adding Month and Month*trib.

\begin{tabular}{lccccc}
\hline Source & DF & Type III SS & Mean Square & F Value & Pr $>$ F \\
\hline tributary & 16 & 16.086 & 1.005 & 2.03 & 0.0093 \\
\hline rl_5turb & 1 & 162.130 & 162.130 & 327.82 & $<.0001$ \\
\hline rl_5turb*tributary & 16 & 14.711 & 0.919 & 1.86 & 0.0206 \\
\hline Xchla & 1 & 9.717 & 9.717 & 19.65 & $<.0001$ \\
\hline xCHLA*tributary & 16 & 21.609 & 1.350 & 2.73 & 0.0003 \\
\hline xInSALINITY & 1 & 0.057 & 0.057 & 0.12 & 0.7339 \\
\hline xInSALINIT*tributary & 16 & 18.498 & 1.156 & 2.34 & 0.0021 \\
\hline
\end{tabular}

Table D-5b. Fit statistics.

\begin{tabular}{lccc}
\hline R-Square & Coeff Var & Root MSE & K $_{\mathrm{d}} \mathbf{1}$ Mean \\
\hline 0.748631 & 31.26545 & 0.703259 & 2.249316 \\
\hline
\end{tabular}

Table D-5c. With Month and Month*Trib in the model.

\begin{tabular}{lccccc}
\hline Source & DF & Type III SS & Mean Square & F Value & Pr > F \\
\hline tributary & 16 & 14.553 & 0.909 & 1.94 & 0.0144 \\
\hline Month & 6 & 5.092 & 0.848 & 1.81 & 0.0942 \\
\hline Tributary*Month & 87 & 62.849 & 0.722 & 1.54 & 0.0016 \\
\hline r1_5turb & 1 & 93.206 & 93.206 & 198.72 & $<.0001$ \\
\hline r1_5turb*tributary & 16 & 16.690 & 1.043 & 2.22 & 0.0037 \\
\hline xCHLA & 1 & 5.522 & 5.522 & 11.77 & 0.0006 \\
\hline xCHLA*tributary & 16 & 19.573 & 1.223 & 2.61 & 0.0005 \\
\hline xInSALINITY & 1 & 0.125 & 0.125 & 0.27 & 0.6055 \\
\hline xInSALINIT*tributary & 16 & 17.341 & 1.083 & 2.31 & 0.0024 \\
\hline
\end{tabular}

Table D-5d. Fit statistics.

\begin{tabular}{lccc}
\hline R-Square & Coeff Var & Root MSE & K $_{\mathrm{d}}$ 1 Mean \\
\hline 0.782748 & 30.44734 & 0.684857 & 2.249316 \\
\hline
\end{tabular}

Of the two seasonal terms, Month and Trib*Month, the Month term is not significant $(p=0.0942)$ and the Trib*Month term is significant $(p=0.0016)$. The increase in $r^{2}$ is only about $3 \%$ which is a not a large increase for the additional 93 degrees of freedom in the seasonal model. The meansquares for the seasonal terms are small. 
I don't believe there is sufficient gain from adding month to warrant the degree of splitting of the data that will be required by doing monthly calibration curves.

\section{Can Tributaries be grouped so that calibration terms are uniform within group?}

At this point, we have established that the model should include three useful predictors: turbidity, chlorophyll, and salinity. These are terms suggested by Chuck Gallegos of the Smithsonian Environmental Research Center, Edgewater, MD, (personal communication) as likely to be important. The question now is whether or not there are groups of tributaries where the intercept and the coefficients for these three predictors are fairly uniform so that they may be lumped for one calibration model. The coefficients are shown in Table D-6. Clearly trying to organize these into uniform groups is complex. To assist with this organization, a cluster analysis was implemented where the tributaries are the items clustered and the coefficients are the attributes to cluster by. Note that because some coefficients are large, but not statistically significant. These data were filtered by statistical significance before clustering by setting all coefficients with p-value $>0.1$ to zero. Note for example the salinity coefficient for the Potomac. At 4.3, the coefficient is nearly two orders of magnitude greater than other salinity coefficient and yet it is not even close to being statistically significant $(\mathrm{p}=0.74)$. The sample size for the Potomac is fairly small and the salinity range for the data collected is also small. These factors contribute to this aberrant coefficient. This illustrates a hazard of splitting data into subsets that are too small. The results of the cluster analysis are illustrated by the dendrogram in Figure D-1.

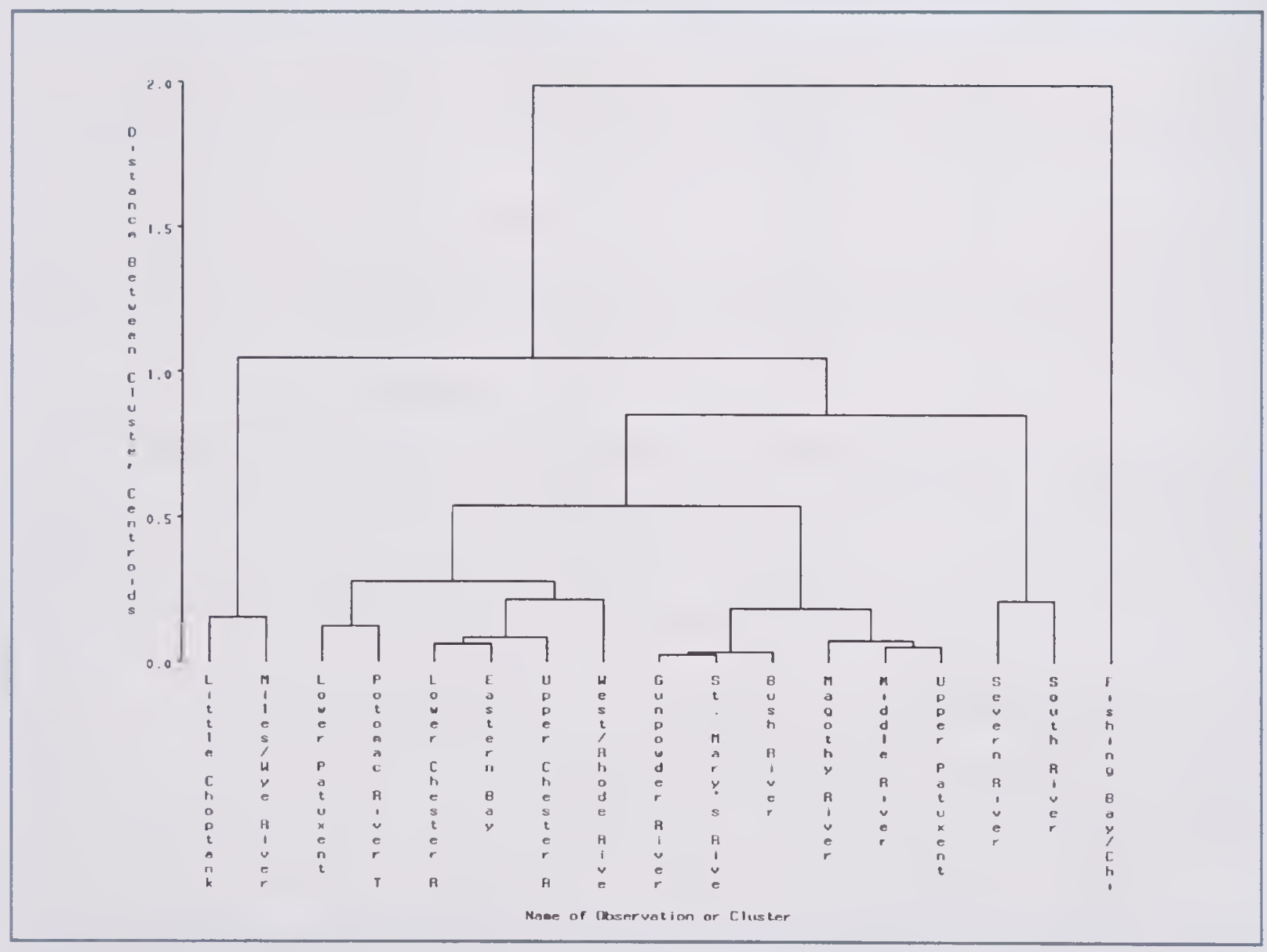

Figure D-1. Dendogram illustrating clustering of Maryland Tributaries by model coefficients. 
Table D-6. Least Square means (LSmean) and model coefficients (upper) and coefficient p-value (lower) for each Tributary. (TurbSlope, chlslope and salSlope $=$ regression coefficients for Turbidity, chlorophyll and salinity respectively; Turbpv, chlpv, salpv = p-value of model coefficient on Turbidity, chlorophyll and salinity).

\begin{tabular}{|c|l|c|l|l|l|}
\hline Obs & Tributary & LSmean & $\begin{array}{c}\text { TurbSlope } \\
\text { Turbpv }\end{array}$ & $\begin{array}{l}\text { chlSlope } \\
\text { chlpv }\end{array}$ & $\begin{array}{l}\text { salSlope } \\
\text { salpv }\end{array}$ \\
\hline 1 & Bush River & 0.66228760 & 0.34563 & 0.020457 & 0.06362 \\
0.000000 & 0.00000 & 0.37814 \\
\hline 2 & Eastern Bay & 0.18462797 & 0.36081 & 0.007857 & 0.04053 \\
& & & 0.000397 & 0.59755 & 0.29528 \\
\hline 3 & Fishing Bay/ & 2.89957195 & 0.35825 & 0.019746 & -0.20987 \\
& Chicamacomico R. & & 0.000000 & 0.20928 & 0.00001 \\
\hline 4 & Gunpowder River & 0.63520230 & 0.29985 & 0.018917 & -0.01304 \\
& & & 0.000000 & 0.02892 & 0.76646 \\
\hline 5 & Little Choptank & -0.81415538 & 0.45633 & 0.041194 & 0.07570 \\
& & & 0.003947 & 0.33639 & 0.32372 \\
\hline 6 & Lower Chester R & 0.11402091 & 0.39440 & 0.010186 & 0.03962 \\
& & & 0.000000 & 0.00000 & 0.24702 \\
\hline 7 & Lower Patuxent & -0.19481321 & 0.29497 & 0.016327 & 0.06830 \\
& & & 0.000000 & 0.02453 & 0.08088 \\
\hline 8 & Magothy River & 0.83013497 & 0.32554 & 0.007115 & 0.03451 \\
& & & 0.002151 & 0.32672 & 0.80087 \\
\hline 9 & Middle River & 0.86931693 & 0.25333 & 0.020142 & 0.03057 \\
& & & 0.000000 & 0.00732 & 0.68222 \\
\hline 10 & Miles/Wye River & -0.64846088 & 0.43871 & 0.017175 & 0.09466 \\
& & & 0.000000 & 0.00117 & 0.05894 \\
\hline 11 & Potomac River T & -0.07347812 & 0.22545 & 0.005387 & 4.31676 \\
& & & 0.010952 & 0.79545 & 0.74414 \\
\hline 12 & Severn River & 1.40514400 & 0.37330 & 0.007781 & -0.08086 \\
& & & 0.000148 & 0.45731 & 0.53781 \\
\hline 13 & South River & 1.57989702 & 0.19308 & 0.023131 & -0.07961 \\
& & & 0.050066 & 0.00284 & 0.07244 \\
\hline 14 & St. Mary's Rive & 0.64822056 & 0.31973 & 0.002694 & 0.00208 \\
& & & 0.000000 & 0.48257 & 0.93330 \\
\hline 15 & Upper Chester R & 0.12031682 & 0.47757 & 0.021069 & 0.04017 \\
& & & 0.000000 & 0.00006 & 0.50339 \\
\hline 16 & Upper Patuxent & 0.92850523 & 0.26910 & -0.008369 & 0.03845 \\
& & 0.000000 & 0.06838 & 0.26144 \\
\hline 17 & West/Rhode Rive & 0.36220019 & 0.25795 & 0.023594 & 0.03514 \\
& & & 0.000031 & 0.00047 & 0.28732 \\
\hline
\end{tabular}

Least Squares Means at $r 1 \_5$ turb $=0.5, x$ CHLA $=3, x \ln S A L I N I T Y=0$

The tributary groups shown in Figure D- 1 are a starting point for organizing the tributaries into groups with similar coefficients. Tributaries that are joined near the bottom of the distance scale have similar coefficients and the similarity decreases as groups are joined further up the distance scale. At the top of the distance scale, all tributaries are in one group. The question is "How far up the distance scale should the groups be formed?" For guidance in addressing this question, we implement a statistical criterion. We try to form tributary groups for which the three predictor 
variables have no statistically significant interaction with tributary. Starting with the groups shown in Figure D-1 and juggling a bit, we arrive at the following groups:

\section{Group 1:}

Bush River

Gunpowder River

St. Mary's River

Magothy River

Middle River

\section{Group 2:}

Lower Patuxent

Potomac River

Eastern Bay

West/Rhode River

\section{Group 3:}

Severn River

South River

Fishing Bay/Chicamacomico

\section{Group 4:}

Little Choptank

Miles/Wye River

\section{Group 5:}

Upper Patuxent

\section{Group 6:}

Lower Chester River

Upper Chester River

These groupings reflect a strong geographical pattern which strengthens their validity. The Upper Patuxent River falls in a group alone because of the negative coefficient for chlorophyll. This coefficient seems quite unusual when juxtaposed with the positive coefficients for all other tributaries. This may be the result of some spatial pattern that is confounded with chlorophyll and warrants additional study.

Shown below are the ANCOVA tables for each group illustrative that the interaction terms lack significance ( $p>0.01$ ) (Tables D-7 thru D-16). Based on these results, we infer that the primary independent variables of the calibration equation: turbidity, salinity, and chlorophyll, have a uniform effect for each tributary group. In some tributary groups, some independent variables, e.g. salinity for group 1, appear to be not important. The model could be reformulated to omit these variables in these tributary groups.

The calibration equations for each tributary group are:

Group 1:

$\mathrm{K}_{\mathrm{d}}=0.5545+0.3172 *\left(\mathrm{rl} \_5\right.$ Turb $)+0.0160 *($ Chlorophyll $a)-0.0138 *($ Salinity $)$

Group 2:

$\mathrm{K}_{\mathrm{d}}=-0.1247+0.2820 *\left(\mathrm{rl} \_5\right.$ Turb $)+0.0207 *($ Chlorophyll $a)+0.0515 *($ Salinity $)$ 
Group 3:

$\mathrm{K}_{\mathrm{d}}=1.0895+0.4160 *\left(\mathrm{r} 1 \_5\right.$ Turb $)+0.0140 *($ Chlorophyll $a)-0.0950 *($ Salinity $)$

Group 4:

$\mathrm{K}_{\mathrm{d}}=-0.8991+0.4338 *\left(\mathrm{rl} \_5\right.$ Turb $)+0.0180 *($ Chlorophyll $a)+0.0912 *($ Salinity $)$

Group 5:

$\mathrm{K}_{\mathrm{d}}=0.8191+0.269 \mathrm{I} *\left(\mathrm{rl} \_5\right.$ Turb $)-0.0084 *($ Chlorophyll $a)+0.0384 *($ Salinity $)$

Group 6:

$\mathrm{K}_{\mathrm{d}}=0.0493+0.4658 *\left(\mathrm{rl} \_5\right.$ Turb $)+0.0100 *($ Chlorophyll $a)-0.0090 *$ (Salinity)

ANCOVA results of $\mathrm{K}_{\mathrm{d}}$-Turbidity regression for tributary groups for Maryland Data

Flow, (run date $=$ December 28, 2006) .

Table D-7. Tributaries in Group 1.

\begin{tabular}{cc}
\hline Tributary Group & Tributaries \\
\hline 1 & Bush River \\
& Gunpowder River \\
& Magothy River \\
& Middle River \\
& St. Mary's River \\
\hline
\end{tabular}

Table D-8. ANCOVA for tributaries in Group 1.

\begin{tabular}{lccccc}
\hline Source & DF & $\begin{array}{c}\text { Sum of } \\
\text { Squares }\end{array}$ & Mean Square & F Value & p-value \\
\hline Model & 19 & 483.54 & 25.45 & 47.13 & 0.0000 \\
\hline tributary & 4 & 0.37 & 0.09 & 0.17 & 0.9530 \\
\hline rl_5turb & 1 & 73.39 & 73.39 & 135.91 & 0.0000 \\
\hline rl_5turb*tributary & 4 & 1.58 & 0.39 & 0.73 & 0.5710 \\
\hline xCHLA & 1 & 11.09 & 11.09 & 20.53 & 0.0000 \\
\hline xCHLA*tributary & 4 & 6.23 & 1.56 & 2.88 & 0.0225 \\
\hline xInSALINITY & 1 & 0.21 & 0.21 & 0.40 & 0.5294 \\
\hline xInSALINIT*tributary & 4 & 0.50 & 0.12 & 0.23 & 0.9218 \\
\hline Error & 390 & 210.60 & 0.54 & - & - \\
\hline Corrected Total & 409 & 694.13 & - & - & - \\
\hline
\end{tabular}


Table D-9. Tributaries in Group 2.

\begin{tabular}{cc}
\hline Tributary Group & Tributaries \\
\hline 2 & Eastern Bay \\
& Lower Patuxent \\
& Potomac River \\
& Wesv/Rhode Rivers \\
\hline
\end{tabular}

Table D-10. ANCOVA for tributaries in Group 2.

\begin{tabular}{lccccc}
\hline Source & DF & $\begin{array}{c}\text { Sum of } \\
\text { Squares }\end{array}$ & Mean Square & F Value & p-value \\
\hline Model & 15 & 95.66 & 6.38 & 27.02 & 0.0000 \\
\hline tributary & 3 & 0.34 & 0.11 & 0.49 & 0.6930 \\
\hline rl_5turb & 1 & 26.26 & 26.26 & 111.27 & 0.0000 \\
\hline rl_5turb*tributary & 3 & 0.61 & 0.20 & 0.86 & 0.4634 \\
\hline xCHLA & 1 & 1.86 & 1.86 & 7.89 & 0.0055 \\
\hline xCHLA*tributary & 3 & 0.78 & 0.26 & 1.10 & 0.3512 \\
\hline xInSALINITY & 1 & 0.06 & 0.06 & 0.24 & 0.6259 \\
\hline xInSALINIT*tributary & 3 & 0.28 & 0.09 & 0.39 & 0.7607 \\
\hline Error & 192 & 45.31 & 0.24 & - & - \\
\hline Corrected Total & 207 & 140.97 & - & - & - \\
\hline
\end{tabular}

Table D-11. Tributaries in Group 3.

\begin{tabular}{cc}
\hline Tributary Group & Tributaries \\
\hline 3 & Fishing Bay/ \\
& Chicamacomico River \\
& Severn River \\
& South River \\
\hline
\end{tabular}


Table D-12. ANCOVA for tributaries in Group 3.

\begin{tabular}{lccccc}
\hline Source & DF & $\begin{array}{c}\text { Sum of } \\
\text { Squares }\end{array}$ & Mean Square & F Value & p-value \\
\hline Model & 11 & 427.39 & 38.85 & 57.35 & 0.0000 \\
\hline tributary & 2 & 1.12 & 0.56 & 0.82 & 0.4410 \\
\hline rl_5turb & 1 & 21.28 & 21.28 & 31.41 & 0.0000 \\
\hline rl_5turb*tributary & 2 & 1.34 & 0.67 & 0.99 & 0.3736 \\
\hline xCHLA & 1 & 3.05 & 3.05 & 4.50 & 0.0357 \\
\hline xCHLA*tributary & 2 & 0.70 & 0.35 & 0.51 & 0.5997 \\
\hline xInSALINITY & 1 & 3.19 & 3.19 & 4.71 & 0.0317 \\
\hline xInSALIN1T*tributary & 2 & 2.17 & 1.08 & 1.60 & 0.2053 \\
\hline Error & 141 & 95.53 & 0.68 & - & - \\
\hline Corrected Total & 152 & 522.91 & - & - & - \\
\hline
\end{tabular}

Table D-13. Tributaries in Group 4.

\begin{tabular}{cc}
\hline Tributary Group & Tributaries \\
\hline 4 & Little Choptank River \\
& Miles/Wye Rivers \\
\hline
\end{tabular}

Table D-14. ANCOVA for tributaries in Group 4.

\begin{tabular}{lccccc}
\hline Source & DF & $\begin{array}{c}\text { Sum of } \\
\text { Squares }\end{array}$ & Mean Square & F Value & p-value \\
\hline Model & 7 & 63.05 & 9.01 & 27.80 & 0.0000 \\
\hline tributary & 1 & 0.03 & 0.03 & 0.09 & 0.7650 \\
\hline rI_5turb & 1 & 13.03 & 13.03 & 40.20 & 0.0000 \\
\hline rl_5turb*tributary & 1 & 0.01 & 0.01 & 0.02 & 0.9010 \\
\hline xCHLA & 1 & 0.90 & 0.90 & 2.79 & 0.0990 \\
\hline xCHLA*tributary & 1 & 0.15 & 0.15 & 0.47 & 0.4939 \\
\hline xInSALINITY & 1 & 1.71 & 1.71 & 5.28 & 0.0244 \\
\hline xInSALINIT*tributary & 1 & 0.02 & 0.02 & 0.07 & 0.7988 \\
\hline Error & 74 & 23.98 & 0.32 & - & - \\
\hline Corrected Total & 81 & 87.04 & - & - & - \\
\hline
\end{tabular}


Table D-15. Tributaries in Group 6.

\begin{tabular}{cc}
\hline Tributary Group & Tributaries \\
\hline 6 & Lower Chester Rivers \\
& Upper Chester Rivers \\
\hline
\end{tabular}

Table D-16. ANCOVA for tributaries in Group 6.

\begin{tabular}{lccccc}
\hline Source & DF & $\begin{array}{c}\text { Sum of } \\
\text { Squares }\end{array}$ & Mean Square & F Value & p-value \\
\hline Model & 7 & 319.82 & 45.69 & 69.54 & 0.0000 \\
\hline tributary & 1 & 0.01 & 0.01 & 0.01 & 0.9165 \\
\hline rl_5turb & 1 & 82.88 & 82.88 & 126.15 & 0.0000 \\
\hline rl_5turb*tributary & 1 & 0.75 & 0.75 & 1.15 & 0.2854 \\
\hline xCHLA & 1 & 16.64 & 16.64 & 25.33 & 0.0000 \\
\hline xCHLA*tributary & 1 & 2.02 & 2.02 & 3.07 & 0.0813 \\
\hline xlnSALINITY & 1 & 0.66 & 0.66 & 1.00 & 0.3175 \\
\hline xInSALINIT*tributary & 1 & 0.00 & 0.00 & 0.00 & 0.9945 \\
\hline Error & 188 & 123.52 & 0.66 & - & - \\
\hline Corrected Total & 195 & 443.35 & - & - & - \\
\hline
\end{tabular}




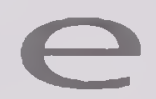

\section{Chesapeake Bay Water Clarity Assessment Framework}

\section{STEP 1. WATER QUALITY PARAMETER INTERPOLATIONS}

Each water quality parameter in each point dataset involved in the particular regionally specific regression model is first interpolated across the segment using the Ordinary kriging function in the Geostatistical Analyst included in the ArcMap software (Figure E-1). All default settings provided by Geostatistical Analyst are used in the interpolations, except for those specified in Table E-1. STAC 2006 (cited in U.S. EPA 2007) indicates that of the various types of interpolation algorithms available and reviewed, ordinary kriging is best positioned to address this issue, i.e., data density from DATAFLOW cruise tracks.

The results of the interpolations are stored in a grid format, where each cell contains a value for the associated water quality parameters. For each segment, all grids used in this analysis are set to the exact same extent (rounded to nearest $25 \mathrm{~m}$ ) and grid cell size $(25 \mathrm{~m} \times 25 \mathrm{~m})$. This ensures that all segment grids correspond spatially when overlayed (Figure E-2).

\section{STEP 2. USING PARAMETER INTERPOLATIONS TO DERIVE $K_{d}$ SURFACE.}

The next step towards calculating water clarity acres is to use the interpolated grids to calculate a $K_{d}$ surface. Turbidity, salinity, and chlorophyll were the three parameters used for determining each of the regionally-specific $K_{d}$ models (see Table IV-2 in Chapter iv, also Appendix D). For each segment, the interpolated chlorophyll, turbidity, and salinity grids are input into the appropriate equation on a cell by cell basis. The result of this cell-specific calculation based on the region-specific multiple regression $K_{d}$ model is a new grid representing the $K_{d}$ surface. 

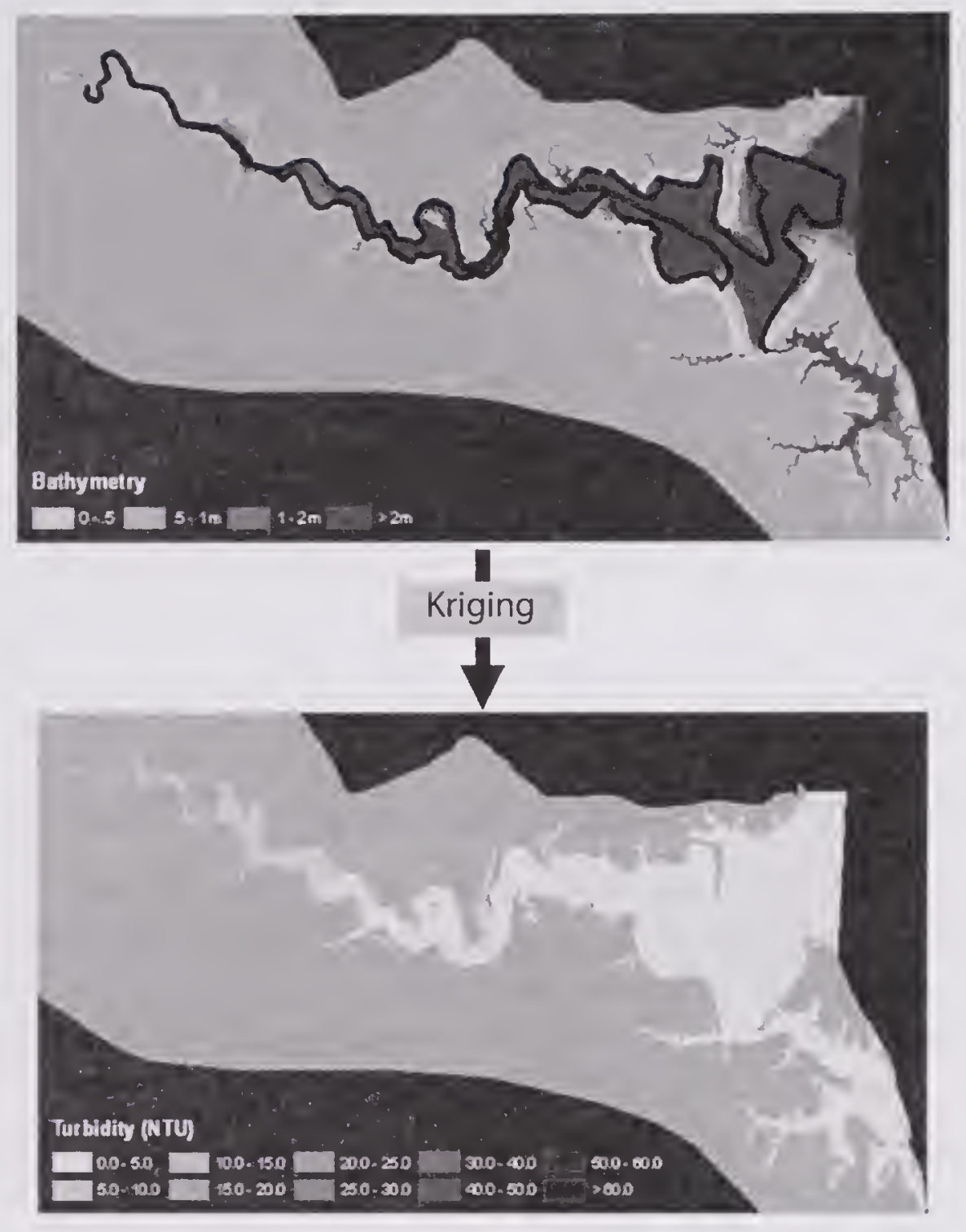

Figure E-1. Turbidity values from the dataflow point dataset (3/17/06) for the Piankatank River Mesohaline Chesapeake Bay Program segment (PIAMH) are used to interpolate a turbidity surface for the entire segment.

Table E-1. Geostatistical analyst settings.

\begin{tabular}{ll} 
Method Type & Ordinary Kriging \\
\hline Model Type & Spherical \\
\hline Max Sample Points & $25 /$ Sector \\
\hline Min Sample Points & 2 \\
\hline Neighborhood Sectors & 4 \\
\hline
\end{tabular}




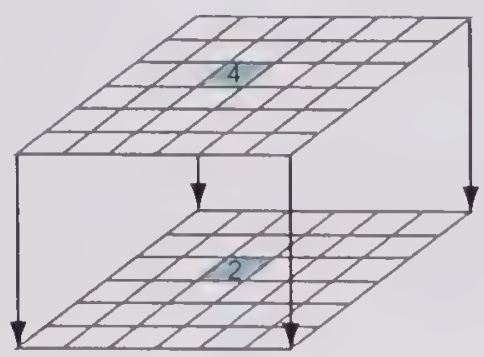

Figure E-2. For each segment, all grids are set to the exact same extent and grid cell size $\left(25 \mathrm{~m}^{2}\right)$. When the grids are overlayed to perform analytical functions, each cell can be analyzed independently. (Source ESRI 2007)

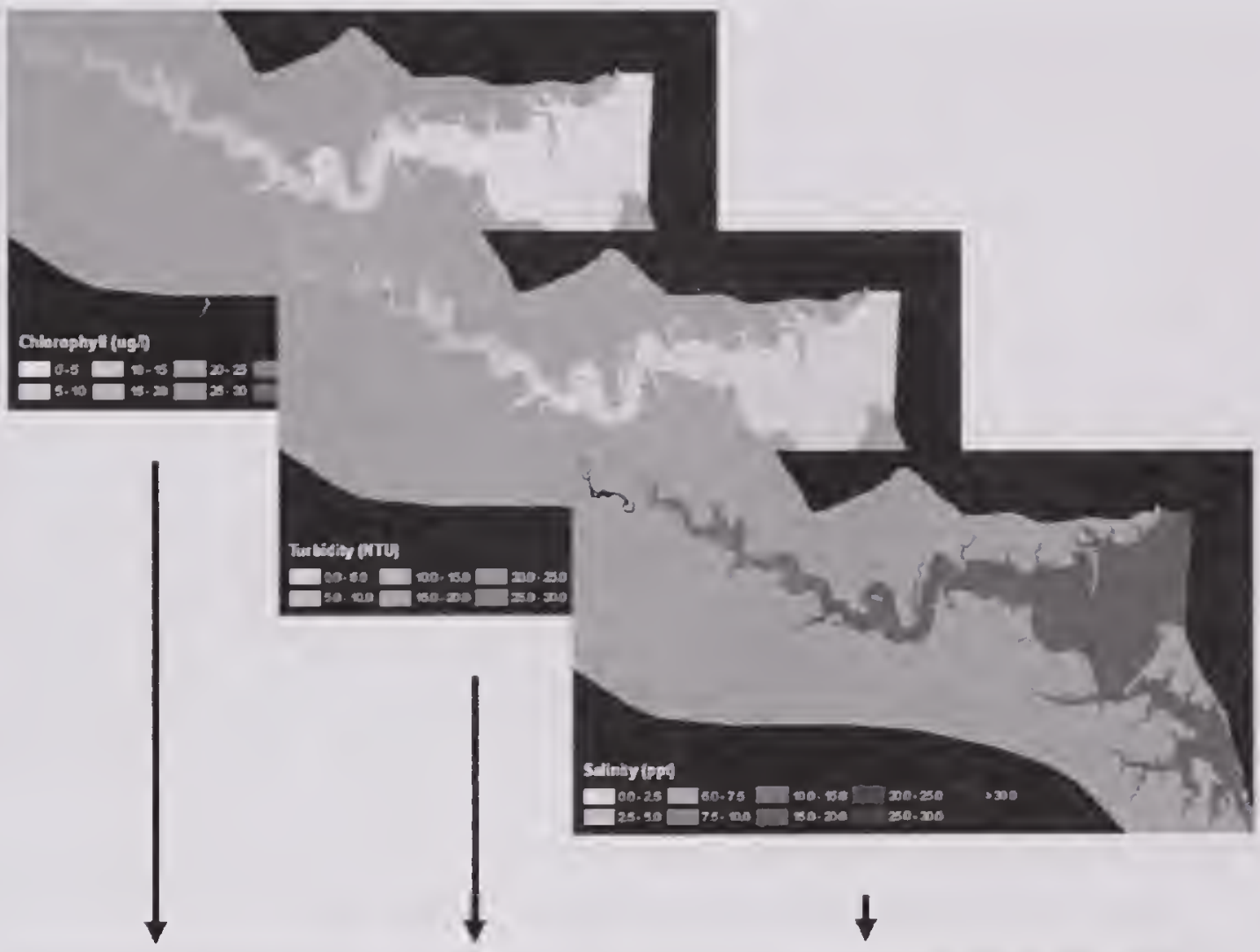

$\mathrm{Kd}=0.5275793536+0.3193475331 \times \sqrt[15]{\mathrm{TU}}+0.0176700982 \times \mathrm{SA}+0.0271723238 \times \mathrm{CH}$

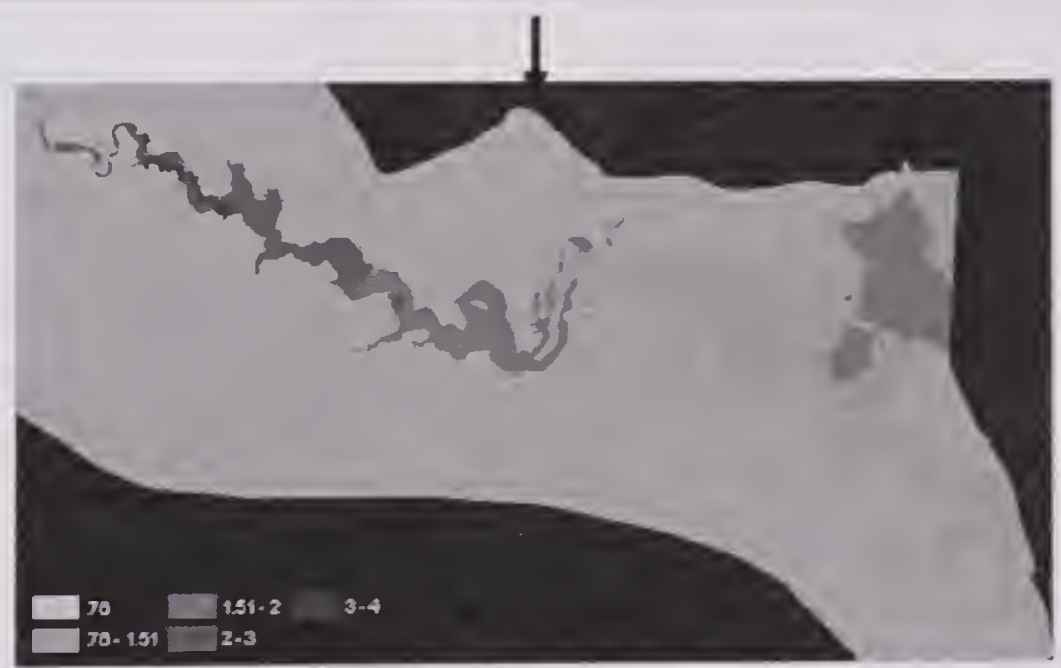

Figure E-3. For each segment, the interpolated chlorophyll $(\mathrm{CH})$, turbidity (TU), and salinity (SA) grids are used to generate a $K_{d}(K d)$ grid. Piankatank River, Mesohaline Chesapeake Bay Program segment (PIAMH) example. 
The next step is to calculate a $K_{d}$ value for each cell and compare this value to a defined threshold.

\section{STEP 3. ATTAINMENT THRESHOLDS}

The following equation defines the relationship between the light attenuation coefficient $\left(\mathrm{K}_{d}\right)$, PLW is the percent light through water, $e$ is the base of the natural logarithms, $K_{d}$ is the value of the light attenuation coefficient, and $\mathrm{Z}$ is depth

$$
\text { Equation 3: } \quad \text { PLW }=100 * \exp ^{(-K} \mathrm{d}^{Z)}
$$

This equation can be used to determine the attainment thresholds at different depths and PLW's (Table E-2).

Table E-2. $K_{d}$ thresholds.

\begin{tabular}{lcccc}
\hline & & \multicolumn{3}{c}{ Zones } \\
\cline { 3 - 5 } PLW & Segment & $\mathbf{0 - 1 \mathbf { m }}$ & $\mathbf{1 - 2} \mathbf{m}$ & $\mathbf{0 - . 5} \mathbf{m}^{*}$ \\
\hline 0.22 & Polyhaline, Mesohaline & 1.51 & 0.76 & 3.03 \\
\hline 0.13 & Oligohaline, Tidal Fresh & 2.04 & 1.02 & 4.08 \\
\hline
\end{tabular}

Each cell in the $\mathrm{K}_{d}$ grid is evaluated against the appropriate 'segment $\mathrm{x}$ zone' threshold. For each segment, two comparisons are performed, one for each depth zone. For example, for Piankatank mesohaline segment, each cell must be less than or equal to the 1.51 threshold for zones where depth is $0-1 \mathrm{~m}$, and less than or equal to 0.76 where depth is $1-2 \mathrm{~m}$. These two comparisons are merged to form an attainment grid (Figure E-4). Each cell in the attainment grid gets a value of one or zero, one if it meets the appropriate threshold and zero if it does not meet the appropriate threshold. Also, any designated Chesapeake Bay exclusion zones are removed from further analysis (Figure E-5).

It is important to identify where this attainment is occurring in relation to other environmental factors. A code system is used to identify the presence/absence of historic and current SAV, and the depth zone for each cell in the grid. To determine the code for each cell in the grid: bathymetry, historic SAV, and current SAV are overlayed (Figure E-6). The resulting grid contains a representative, 3-digit code for each cell. The first digit indicates which bathymetric zone the cell is in, the 2nd digit designates whether historic SAV is present or absent, and the last digit indicates whether current SAV is present or absent (Figure E-7). Finally, the attainment grid and zone codes are combined and the results are exported in table format to an ACCESS database for further analysis (Figure E-8). This method groups the attainment data by 
unique zone codes, for example, there may be 463 cells that were in attainment for cells in 1-2 $\mathrm{m}$ of depth, where current and historic SAV are present.

ACCESS is used to calculate water clarity acres by initially converting cell counts of attainment into acreage of attainment inside and outside of current SAV areas for each segment. Water clarity acres for the segment are then calculated by the taking the annual mean of the monthly acreage. Finally, the annual water clarity acreage is compared with the segment goals as defined in DEQ document 9 VAC 25-260 Virginia Water Quality Standards (2005).

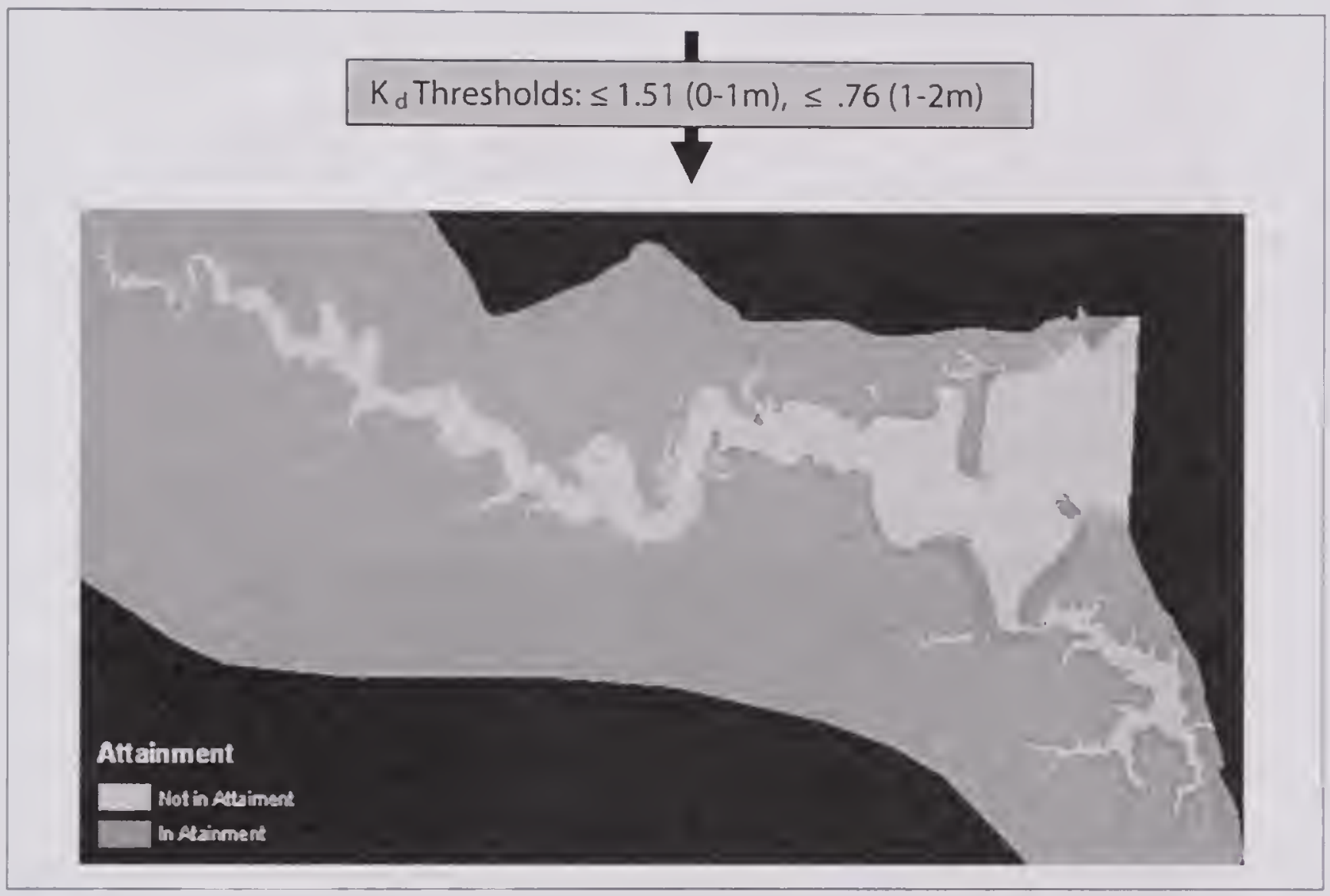

Figure E-4. The $K_{d}$ grid is compared to the appropriate $K_{d}$ threshold on a cell by cell basis to create the attainment grid.

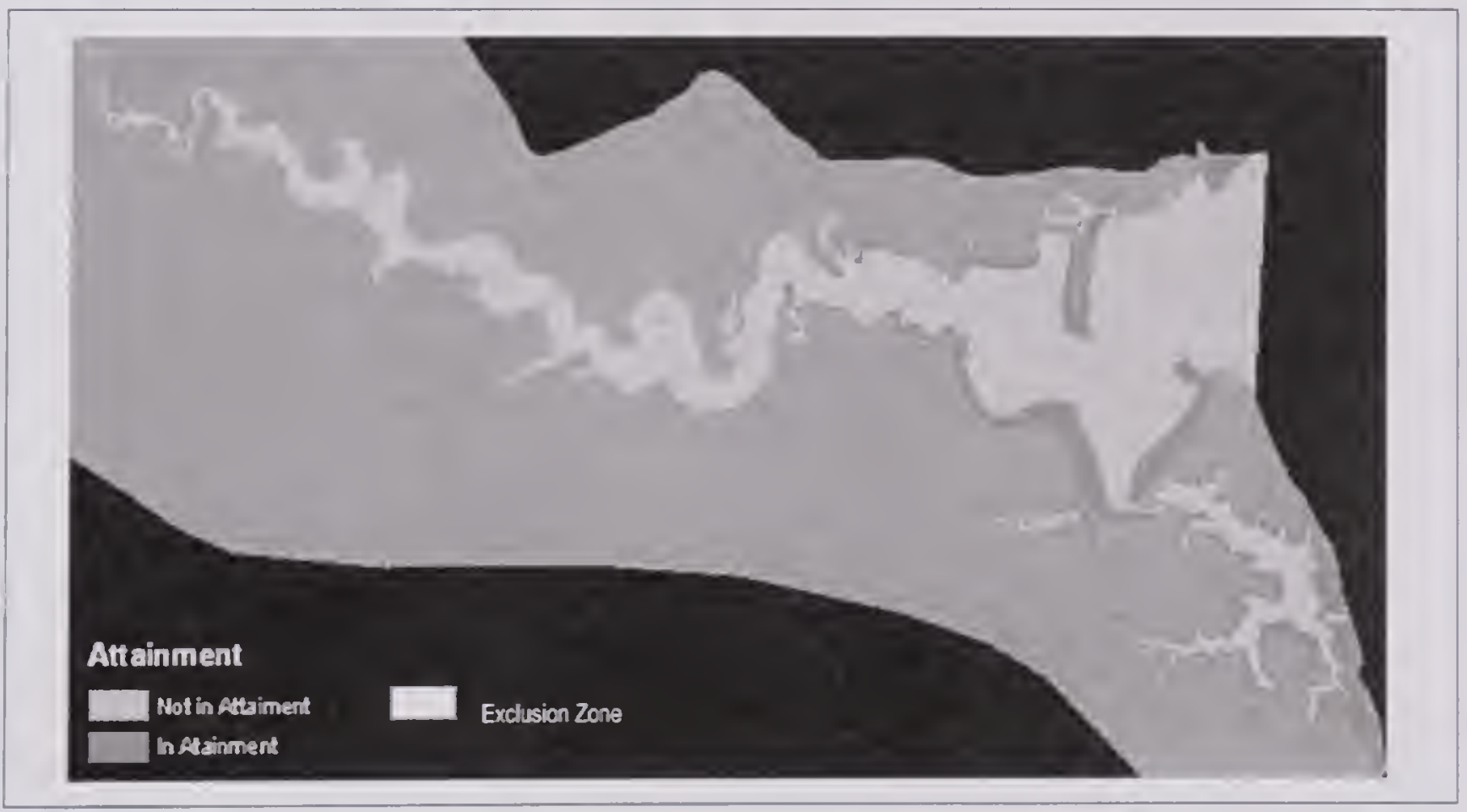

Figure E-5. Chesapeake Bay exclusion zones are removed from further analysis. 


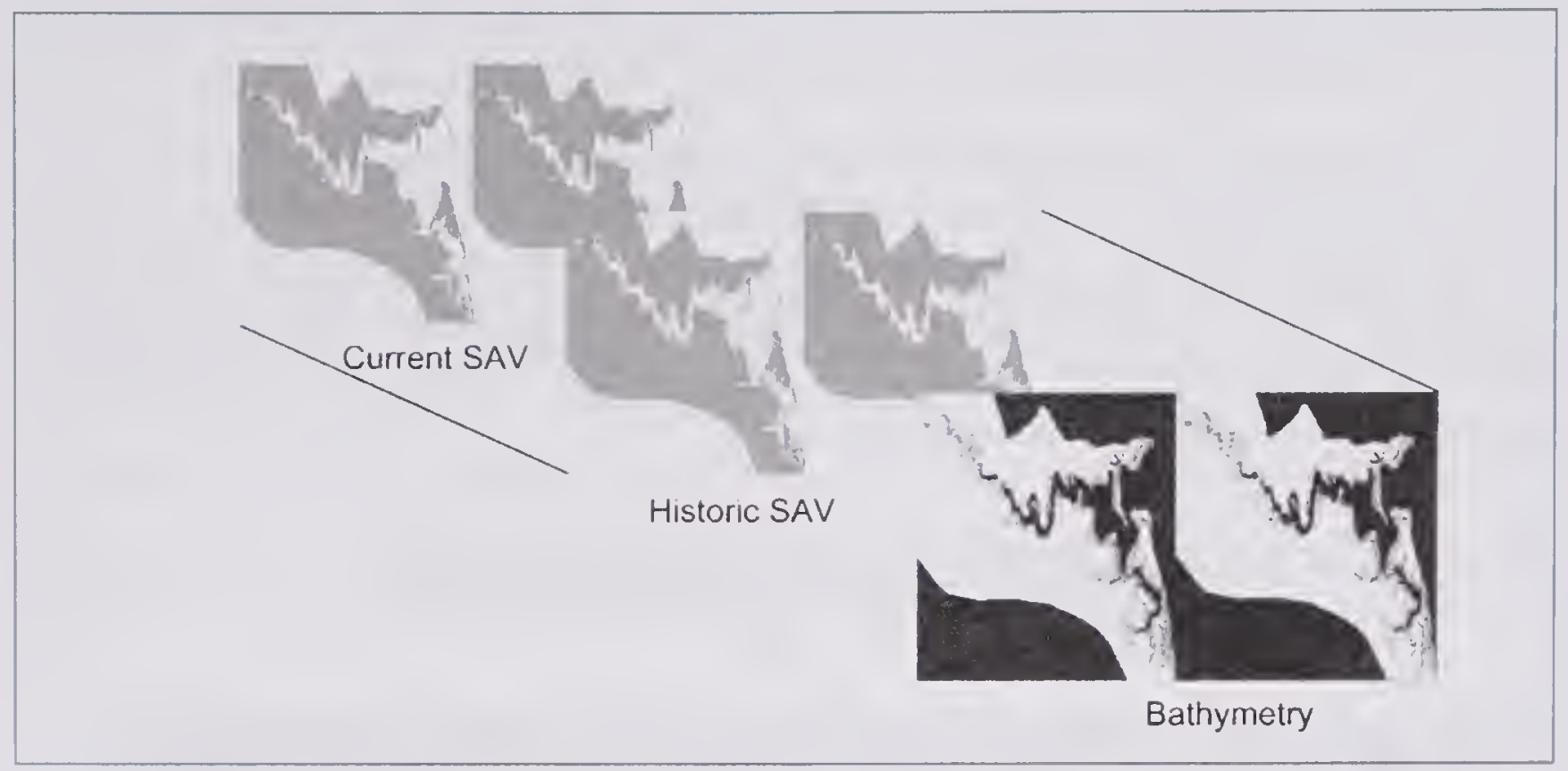

Figure E-6. Bathymetry, historic SAV, and current SAV are overlayed to determine a unique code that describes environmental attributes for each cell in the study area.
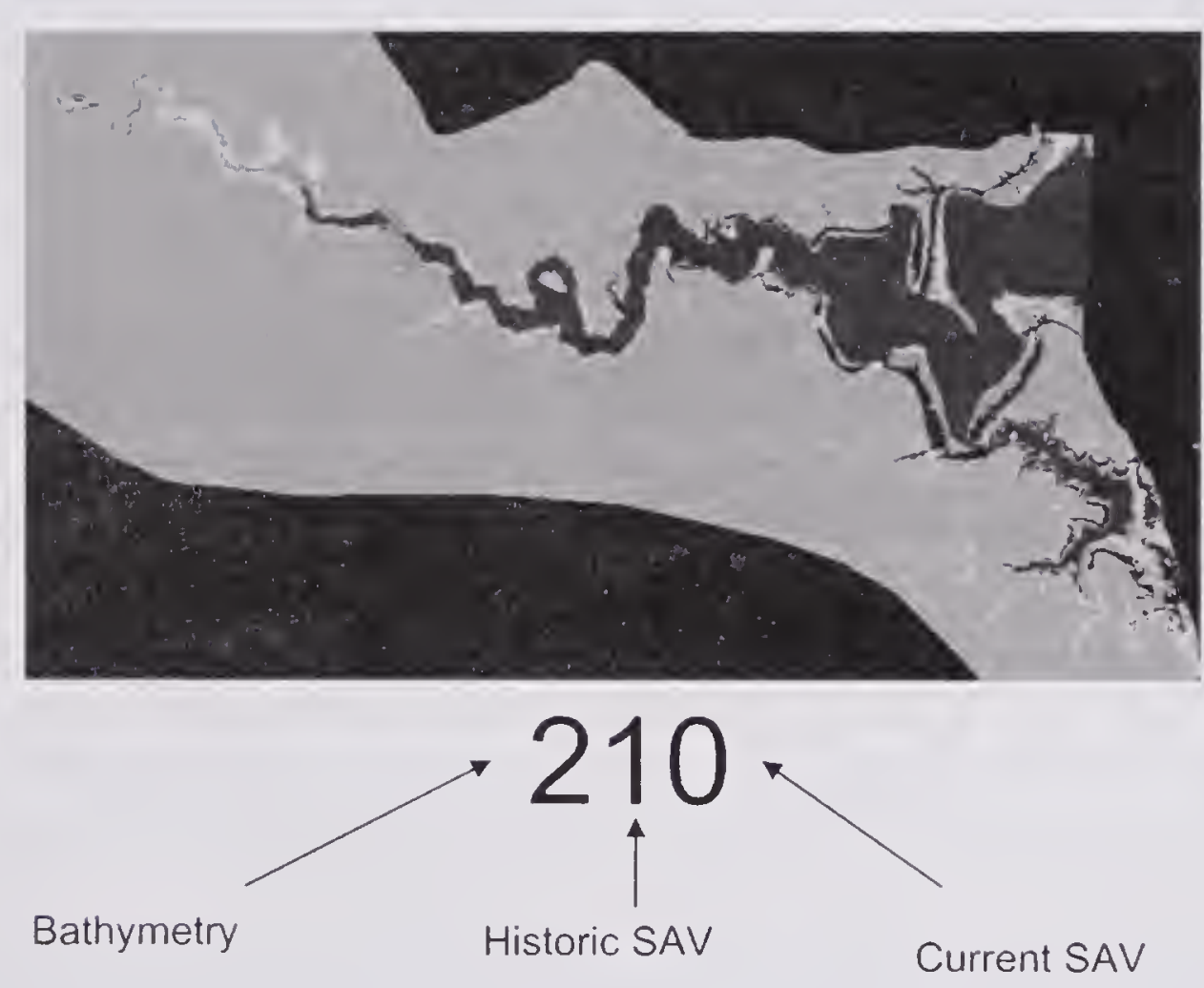

Figure E-7. A representative 3-digit code for each cell is used to indicate bathymetric zone, historic SAV presence/absence, and current SAV presence/absence. 


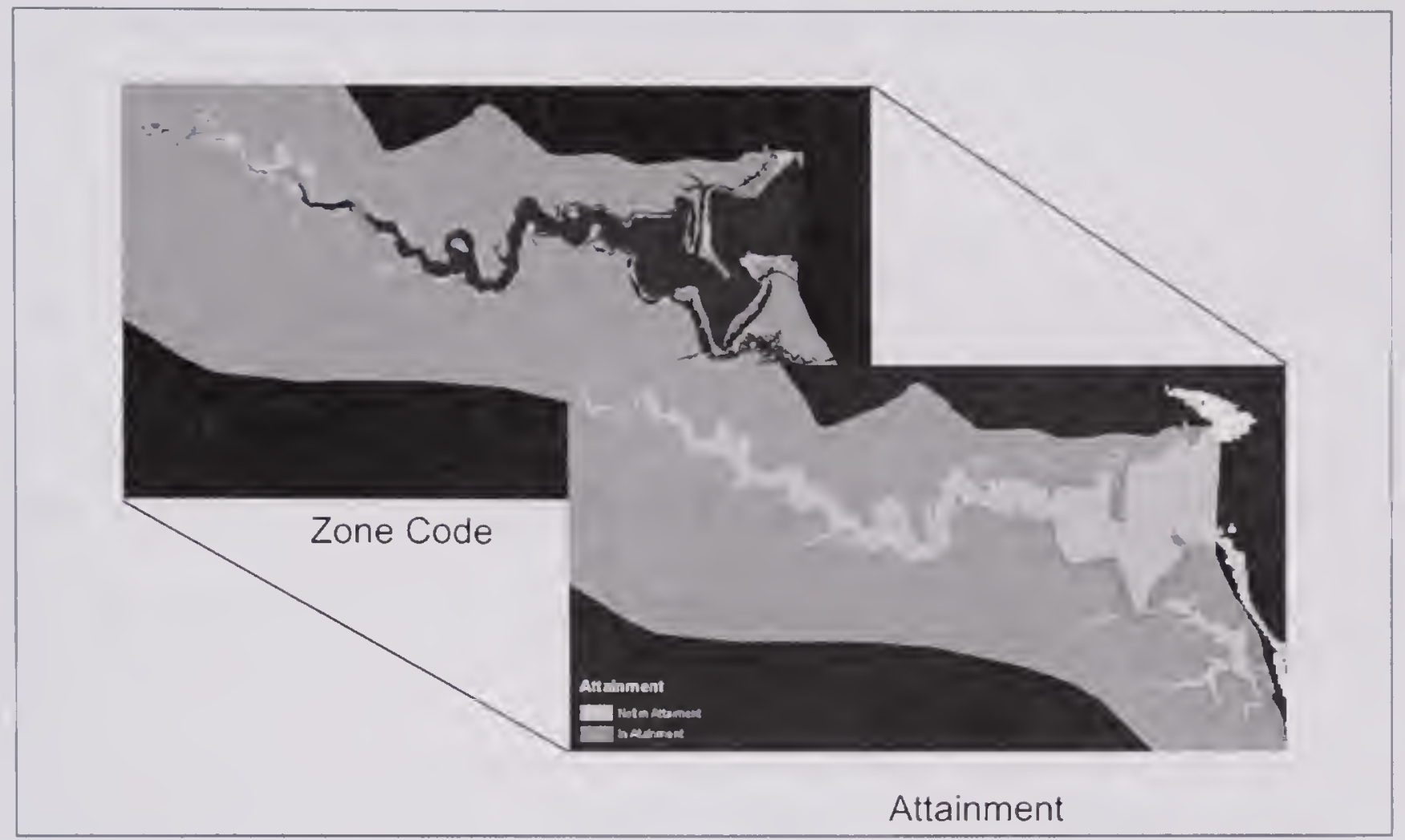

Figure E-8. The attainment grid and zone codes are combined and the results are exported to an access database for further analysis.

\section{LITERATURE CITED}

Environmental Systems Research Institute (ESRI). 2007. ArcGIS 9.2. Redlands, CA.

Scientific and Technical Advisory Committee (STAC). 2006. The Cumulative Frequency Diagram Method for Determining Water Quality Attainment: Report of the Chesapeake Bay Program STAC Panel to Review Chesapeake Bay Analytical Tools. STAC Publication 06003. 9 October 2006. Chesapeake Bay Program Scientific and Technical Advisory Committee, Chesapeake Research Consortium, Edgewater, MD.

U.S. Environmental Protection Agency. 2007. Ambient Water Quality Criteria for Dissolved Oxygen, Water Clarity and Chlorophyll a for the Chesapeake Bay and Its Tidal Tributaries 2007 Addendum, July 2007. EPA 903-R-07-003 Region III Chesapeake Bay Program Office, Annapolis, MD. 21403.

9 VAC 25-260 Virginia Water Quality Standards. 2005. § 62.1-44.15 3a of the Code of Virginia. Retrieved February 21, 2007 from http:/www.epa.gov/waterscience/standards/ wqslibrary/va/va_3_wqs.pdf 


\section{appendix $f$ \\ Water Clarity Attainment Results}

\section{ASSESSMENT MARYLAND WATER CLARITY ATTAINMENT RESULTS}

Analyses were conducted for the 2004-2006 time period, with the exception of the Magothy and Severn Rivers where DATAFLOW data were evaluated for the 2001-2003 period.

- For Maryland, the following segments had no SAV goal, therefore the analysis was not applicable: BACOH, CHOTF, CHSTF, NANTF, POCOH, POCTF.

- For Maryland, the following segments passed their SAV goal in at least one year between 2004 and 2006: CHSOH, BSHOH, BOHOH, CB2OH, PAXTF, NORTF, SASOH, C\&DOH, PAXOH, MATTF

- For Maryland, the following segments failed their SAV goal for each year between 2004 and 2006 and had incomplete or no data to perform the water clarity acres assessment: TANMH, CB5MH, MANMH, POCMH, CB4MH, NANMH, NANOH, POTTF, PISTF, POTOH, CHOMH1, POTMH, LCHMH, $\mathrm{CHOMH} 2, \mathrm{CHOOH}$, WICMH

- For Maryland, the following segments passed using the water clarity acres assessment method: GUNOH, FSBMH, SEVMH, RHDMH

- For Maryland, the following segments failed using the water clarity acres assessment method: MAGMH, CHSMH, EASMH, WSTMH, PAXMH, SOUMH

- For Maryland, the following segment failed due to insufficient spatial coverage of DATAFLOW data during its three year assessment cycle: MIDOH

\section{DETAILED RESULTS FOR WATER CLARITY ASSESSMENT METHOD}

The Appendix contains detailed information regarding each segment where the water clarity assessment method was employed. Monthly pass/fail clarity maps addition to the annual averages in relation to the SAV goals. Below are short narratives 
describing any information that was pertinent to the assessment and possible explanation of why a segment passed or failed.

\section{GUNOH}

The Gunpowder was very close to meeting its SAV goal (2392.1 out of 2432) for 2004, so it was relatively easy to obtained the 99.75 water clarity acres needed to pass.

\section{SEVMH}

The Severn was assessed for the year 2002. During the inception of the DATAFLOW program in 2001 and 2002, the data on the Severn and Magothy Rivers were collected twice monthly from April through October. Most passing water clarity was observed at the southern shore near the mouth and the SAV margin areas in the vicinity of Round Bay.

\section{$\mathrm{MIDOH}$}

Middle River was assessed with DATAFLOW data for 2004. In all three years of DATAFLOW assessment, cruise tracks were only conducted within the Middle River proper. The MIDOH segment however also encompasses Seneca Creek and part of the main-Bay to the north. During the interpolation process, water clarity acres were not extrapolated into the unsampled areas of Seneca Creek. This therefore meant that a smaller assessment area was used to try and obtain the goal for the entire segment. Using this method resulted in a failure of the threshold. If the water clarity pass/fail percentage was extrapolated to the entire shallow-water area of the segment, the segment would pass.

\section{MAGMH}

Unlike the Severn, the relatively large shallow areas at the mouth of the Magothy continuously failed the criteria in 2002, resulting in failure for the entire segment. Perhaps the orientation of the Magothy makes it more vulnerable to open Bay wave action and Susquehanna turbid outflow.

\section{$\mathrm{CHSMH}$}

It should be noted that the 2004 assessment for the lower Chester relied on data from two separate cruises for each month. These cruised were interpolated separately. The general demarcation line between the two cruises was just south of the Corsica River. CHSMH was only at $25 \%$ of its SAV goal of 2928 acres and was therefore difficult to consistently obtain the large area of water clarity needed for it to pass.

\section{EASMH}

Eastern Bay was assessed for 2004 and only had 16.7\% of its 6209 acre goal. It therefore had to achieve an enormous acreage of 12923.5 acres of combined acreage to pass. It did very well, achieving an average of 9228 acres, but not enough to pass. 


\section{SOUMH}

The South River was assessed for 2004. It had a low SAV acreage and ultimately the average water clarity did not even meet the SAV goal, let alone 2.5 times the goal.

\section{FSBMH}

Fishing Bay passed mainly on the back of its small goal and a few months producing good water clarity in the shoreline margins of the lower open water portions. These areas ultimately might not support SAV due to the high wave energy and shifting sediments of this segment.

\section{PAXMH}

Very little SAV is to be found in the lower Patuxent that also has a large SAV goal. Fifty-four percent of the water clarity goal was achieved.

\section{RHDMH/WSTMH}

The Rhode River, much like Fishing Bay, owes some of its passing success to a small goal (60 acres). No appreciable SAV has been observed in this segment during the VIMS aerial surveys. Much of the passing water clarity for the West and Rhode were observed in the downriver portions. This segment also contains shoreline along the Bay that had better estimated water clarity. The West River failed due to consistently bad upriver turbidity.

\section{ASSESSMENT VIRGINIA WATER CLARITY ATTAINMENT RESULTS}

Analyses were conducted for the 2004-2006 time period.

- For Virginia, the following segments had no SAV goal, therefore the analysis was not applicable: MPNOH, PMKOH, SBEMH, WBEMH, EBEMH, ELIPH, LAFMH.

- For Virginia, the following segments passed their SAV goal in at least one year between 2004 and 2006: CHKOH, MPNTF, PMKTF, POTOH, POTTF, RPPOH, RPPTF

- For Virginia, the following segments failed their SAV goal for each year between 2004 and 2006 and had no data to perform the water clarity acres assessment: CB5MH, CB6PH, CB7PH, CB8PH, CRRMH, LYNPH, MOBPH, POCMH, POTMH, RPPMH, TANMH

- For Virginia, the following segments passed using the water clarity acres assessment method: CHKOH, JMSMH, JMSPH, MPNTF, PMKTF

For Virginia, the following segments failed using the water clarity acres assessment method: APPTF, JMSOH, JMSTF1, JMSTF2. PIAMH, YRKMH, YRKPH 
Table F-1 summarizes these results of water clarity attainment results in Virginia segments for the single best year among the three year period of 2004 through 2006.

Table F-1. 2008 305b/303d list segment water clarity/SAV acres attainment assessment results.

\begin{tabular}{lcc}
\hline CBP Segment & $\begin{array}{c}\text { Single Best Year Meets } \\
\text { "SAV Acres Criteria" }\end{array}$ & $\begin{array}{c}\text { Single Best Year Meets } \\
\text { "Water Clarity Acres" Criteria }\end{array}$ \\
\hline APPTF & NO & NO \\
\hline CB5MH & NO & ND \\
\hline CB6PH & NO & ND \\
\hline CB7PH & NO & ND \\
\hline CB8PH & NO & ND \\
\hline CHKOH & YES & YES \\
\hline CRRMH & NO & ND \\
\hline EBEMH & YES & ND \\
\hline JMSMH & NO & YES \\
\hline JMSOH & NO & NO \\
\hline JMSPH & NO & YES \\
\hline JMSTF1 & NO & NO \\
\hline JMSTF2 & NO & NO \\
\hline LYNPH & NO & ND \\
\hline MOBPH & NO & ND \\
\hline MPNTF & YES & YES \\
\hline PIAMH & NO & NO \\
\hline PMKTF & YES & YES \\
\hline POCMH & NO & ND \\
\hline POTMH & NO & ND \\
\hline POTOH & YES & ND \\
\hline POTTF & YES & ND \\
\hline RPPMH & NO & NO \\
\hline RPPOH & YES & NES \\
\hline YRKPH & NO & NO \\
\hline
\end{tabular}

ND: No shallow-water monitoring DATAFLOW data collected during the assessment period. 


\section{sprenandix $\mathrm{g}$ \\ Chlorophyll a Assessment Protocol}

\section{STEP 1. CALIBRATING DATAFLOW CRUISE-TRACKS}

1. Locate the CPB segments where DATAFLOW cruise-track points are located using GIS. Although VIMS and Hampton Roads Sanitation District (HRSD) have cruise-tracks organized by segment, the ends of cruise-tracks "spill" over into adjacent segments. Points need to be regrouped prior to calibration since each segment has its own regression equation.

2. Organize records for verification stations by segment and season (spring and summer). Each verification station should have extracted and YSI chlorophyll for each sampling date, along with turbidity and temperature data.

3. A calibration equation should be determined for each segment-season combination by calculating a $\log$-ratio (logExtracted - $\log$ YSI) for each verification event, regressing it over concomitant temperature and turbidity values to determine a predicted log-ratio, and multiplying the backtransformed predicted log-ratio by the YSI chlorophyll to estimate the extracted chlorophyll for cruisetrack points.

\section{STEP 2. SETTING UP THE DATA SET}

4. Compile a chlorophyll database for the assessment period containing records from the following stations:

a. Long-term CBP stations (records stored in CIMS database)

b. DFLO verification stations (records stored in CIMS database)

c. VA DEQ stations (records stored in VA DEQ CEDS database)

d. DFLO cruise-tracks (records stored by VIMS/HRSD).

5. Database should contain station name, UTM Easting and Northing coordinates (NAD83), laboratory-extracted chlorophyll values (ug/l), sampling date, sampling depth (only depths less than or equal to $1.0 \mathrm{~m}$ should be used), and 
QA/QC comments. Fields that distinguish the project and source for each record should also be created, to allow for station filtering. In addition, you may also want to create a field for segment ID (e.g., OH, TF1, MH, etc.) for each record.

6. In this master dataset, create a field called "input". This will be the field that will be copied and pasted into the Interpolator.

The Interpolator reads a record with the following format: EASTING,NORTHING,DEPTH,PARAMETER,STATION

The "input" field should be a concatenation of the pertinent fields in your master database. A comma is needed between each value, so create a "comma" field that you reference in the concatenate formula.

7. Replicate samples should be averaged together prior to interpolation if the time scale you have chosen is greater than a day. This is because the interpolator will automatically average multiple observations present. If the interpolator is a daily interpolation, the interpolator will take the replicates on that day and average them as is appropriate. However, if it is a monthly interpolation, and the daily replicates have not been previously averaged into a single value, then the replicates will be treated as independent observations and given undue weight in the monthly average.

8. The QA/QC field should be reviewed and only data meeting appropriate QA/QC requirements should be used in the following interpolation steps. Cruise-track data associated with such codes as NQR, NNF, GPF, and GNV are to be excluded, while data flagged as algal blooms (CAB) should be left in. In Virginia, consult the table in the Data Disclaimer and Info section of www.vecos.org for a description of codes.

\section{STEP 3. IMPORTING THE DATA INTO THE INTERPOLATOR}

9. Filter the master database so that it only shows data for the specific time period (e.g., March 1,2005) and from the type of stations (e.g., long-term CPB stations) that is desired. Fixed stations alone should be interpolated by month, while fixed stations + DFLO cruise-tracks should be interpolated by day.

10. Copy and paste the "input" field into a text editor, such as Notepad.

11. The first five lines of this text file are descriptive, providing info to both the reader and the Interpolator. They should look something like this:

CHL for James March 2005 long-term CPB stations

CHL, Chlorophyll concentration

05/02/2005,05/25/2005

07/10/2007:11:25

127

The first four lines provide general information (which would show if you generated a map). The third line gives the range of sampling dates for the input data, and the fourth line gives the current date and time (you can put any date and time, but it should be formatted as shown). The fifth line is the critical one for the Interpolator. This is the number of data points in the input. If this number is 
larger than the actual number of records, an error message will be generated and the program will shut down.

12. The analyst should load in all points from a cruise-track, including even the points beyond a segment's boundary. Fixed station data collected on the date of a cruise-track should also be included in the file.

13. Save this file with a descriptive title and save it in the same directory as the Interpolator .exe. The program will only load files from its directory.

14. Open the Interpolator and follow the radio buttons from left to right. Select James under Geography and chlorophyll concentration (two decimal places) under Parameter. Open your text file under Data Import (scroll down to see "All files"). The fields should populate automatically when the file is loaded. Then, click on Parameter Transformation and scroll down to "In". Click on the Interpolate button and select "2D Inverse-Distance Squared". The defaults should not be altered. The program should then begin interpolating the data.

15. Using Notepad or Excel, open the ".est" file that has been generated. This "estimates" file gives you the interpolator cells, by segment, and their estimated chlorophyll values.

16. The ".log" file counts and lists the records used to interpolate each segment.

\section{STEP 4. AVERAGING THE DATA}

17. A seasonal average for a specific year should be determined by averaging the individual interpolations done on data culled from narrower time-frames within that season. For instance, the interpolations of daily cruise-tracks occurring between March and May 2005 should be averaged together to create an estimate for spring 2005.

18. The Interpolator has a Math function that will average the interpolation coverages from individual ".est" files. The advantage of using this function is in its convenience, but there is one disadvantage: the program is inflexible when it comes to missing data. If one file has a missing value for a cell (which arises when there were no data points within the predefined search radius of that particular cell), the Interpolator ignores the data contained in the other .est files for that cell, resulting in a missing value (-9) in the average output. The analyst may choose to bypass the Math function and do the cell-by-cell averaging in a spreadsheet, so that missing values can be replaced with blanks. After calculating the seasonal average, values that are still missing should be replaced with a null character, such as a period or an asterisk.

19. If interpolations are based primarily on daily cruise-tracks, then averages should be calculated separately for each segment-year. For each segment, the assessment spreadsheet should use only the days of targeted DATAFLOW cruises, since these dates will provide good estimates for only the targeted segment. The only other interpolated dates that should be used in the assessment spreadsheet for a segment's assessment are: I) those with records for at least two fixed stations and 2) those in which an adjacent segment was targeted by a DFLO 
cruise AND there is a record for at least one fixed station not located particularly close to the boundary of the targeted segment.

20. The seasonal averages for each interpolator cell should then be inserted into a spreadsheet designated for the assessment.

\section{STEP 5. DESIGNING THE ASSESSMENT SPREADSHEET}

21. Set up the spreadsheet where the assessment will be done. It should have columns corresponding to the interpolator cells (or centroids)-either as a unique ID the analyst has created or as the UTMx and UTMy coordinates assigned to those centroids. A field containing segment identification (e.g., "TFl" or "PH") should also be created. The sequence of the centroids should match exactly with the sequence from the ".est" file, to allow for easy copying and pasting.

22. Because only the James River main stem requires assessment, certain centroids need to be excluded from the analysis. It is recommended that the analyst keep these centroids on the spreadsheet, but that instead of being assigned a segment ID (e.g., "CHKOH"), they should be marked with a null character, such as a period or an asterisk. Along with the centroids within Appomattox and Chickahominy segments, individual JMS centroids falling in small embayments and non-CPB tributaries (like the Pagan River) should be restricted from the assessment. GIS can be used to identify these centroids.

23. Create a field called "chlorophyll". This is where the Interpolator estimates will be inserted.

24. The next field will contain the assessment binary ("pass" or "fail") for each centroid. Because each segment has a different criterion, an "IF" statement similar to the following should be created:

=IF(chlorophyll=".,, “.,,IF(chlorophyll>criteria,"fail”, "pass”))

where chlorophyll $=$ chlorophyll value for centroid

$" . "$ = null value (if centroid has missing data)

criteria $=$ chlorophyll value the centroid is being assessed against

fail $=$ exceeds the criteria

pass $=$ less or equal to the criteria

The statement, reduced to layman's terms, says: "If the chlorophyll value for this cell is missing, insert a null value. If it's greater than this specified value, insert a 'fail'. If it's less than or equal to this specified value, insert a "pass'."

In Virginia, refer to the table on page 35 of the Water Quality Assessment Guidance Manual for Y2008 for the criteria for each segment and season.

25. A table should be created that tallies up the number of "fails" for each segment and calculates a percentage of "fails" from the total number of cells in a segment. This percentage will be used to calculate the CFD. In addition, the analyst should also calculate the percent of area interpolated for each segment by tallying up the number of null characters in the assessment field. 
26. Assessment spreadsheets should be created for each season (i.e., spring 2004, 2005, 2006 and summer 2004, 2005, 2006). Spreadsheets for spring chlorophyll estimates should have spring assessment criteria; likewise for "summer" spreadsheets.

\section{STEP 6. CREATING THE CFD}

27. The percent non-attainment for each assessed segment, at each season, should be copied and pasted into another spreadsheet. Organize them into columns corresponding to segment-season. For instance, label column 1 as "TF1 spring" and insert all the spring percent non-attainment values for TF1 into this column. In the next field insert all the spring percentages for "TF2 spring". Continue doing this for all segment-season combinations. These columns correspond to the "\% space" axis on the CFD.

28. Sort them in descending order.

29. To generate the "\% time" axis, use the following equation:

$=\left(100^{*} \mathrm{R}\right) /(\mathrm{N}+1)$

where $\mathrm{R}=\operatorname{rank}$ ("1" for the first time point, "2" for the second", "3" for the third and " 4 " for the last).

$\mathrm{N}=$ number of time points. Since the assessment period consists of three seasonyears, this number is equal to 3 .

30. For each $\%$ space column, insert $100 \%$ at the top of the column and $0 \%$ at the bottom. For the \% time column, insert $0 \%$ at the top of the column and $100 \%$ at the bottom.

31. You can now create the assessment curve.

32. To calculate $\%$ space for the $10 \%$ reference curve, use the following equation:

$\%$ space $=[\mathrm{a} /(\mathrm{y}+\mathrm{b})]-\mathrm{b}$

where $\mathrm{y}=\%$ time

$\mathrm{b}=0.042995$

$a=b^{2}+b$

33. You can now create the $10 \%$ reference curve.

\section{STEP 7. CALCULATING THE PERCENT EXCESS NON-ATTAINMENT}

34. Convert the percentage axes of the CFD to fractional axes for this calculation.

35. The trapezoidal rule should be applied to both assessment and reference curves to determine the area underneath each curve. The following website describes how to do the calculations using MS Excel: www.montanamath.org/ TMME/v4nl/TMMEv4nla6.pdf

36. Subtract the area under the assessment curve from the reference curve, looking only at the parts of the assessment curve that go beyond the reference curve.

37. Multiply the value by 100 . This number represents "\% excess non-attainment". 


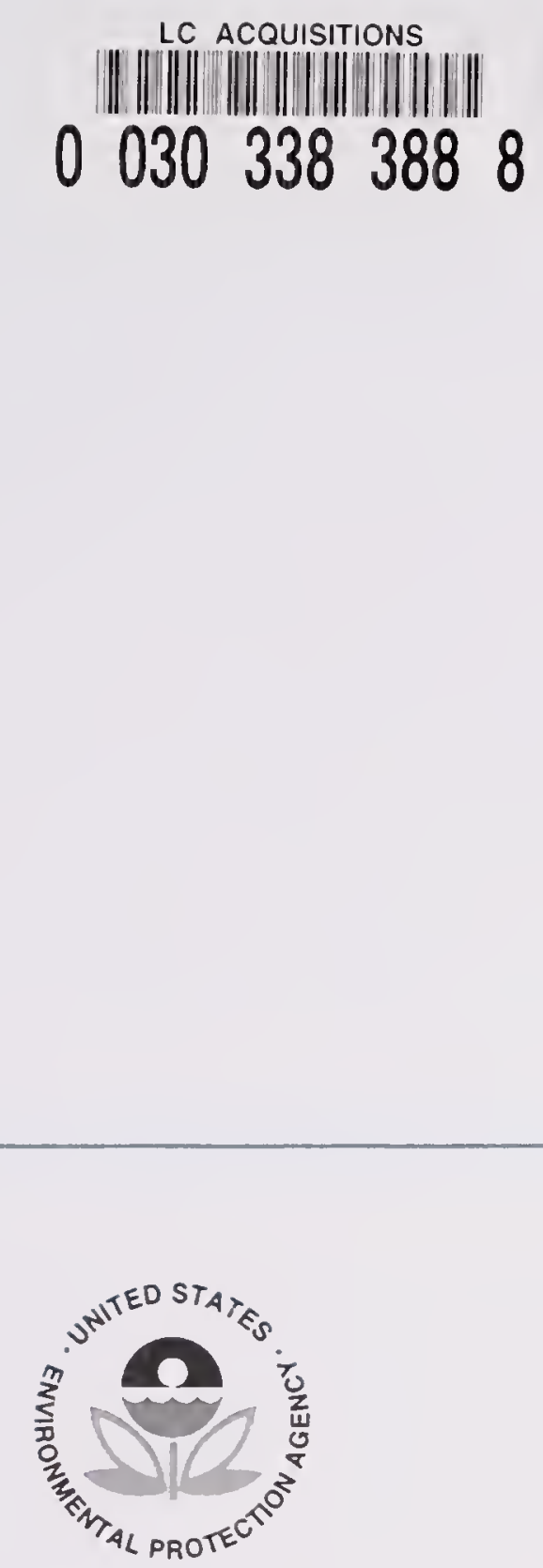

U.S. Environmental Protection Agency

Region III

Chesapeake Bay Program Office

Annapolis, Maryland

1-800-YOUR-BAY

$$
\text { and }
$$

Region III

Water Protection Division

Philadelphia, Pennsylvania

in coordination with

Office of Water

Office of Science and Technology

Washington, D.C.

$$
\text { and }
$$

the states of

Delaware, Maryland, New York,

Pennsylvania, Virginia and

West Virginia and the District of Columbia 


R

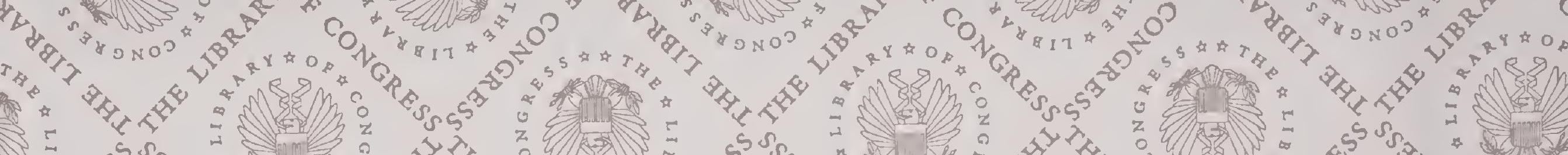
o

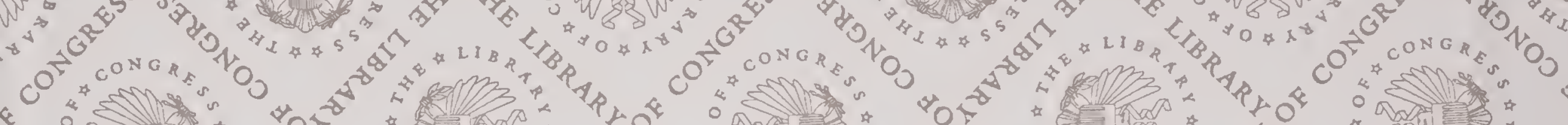
a 等

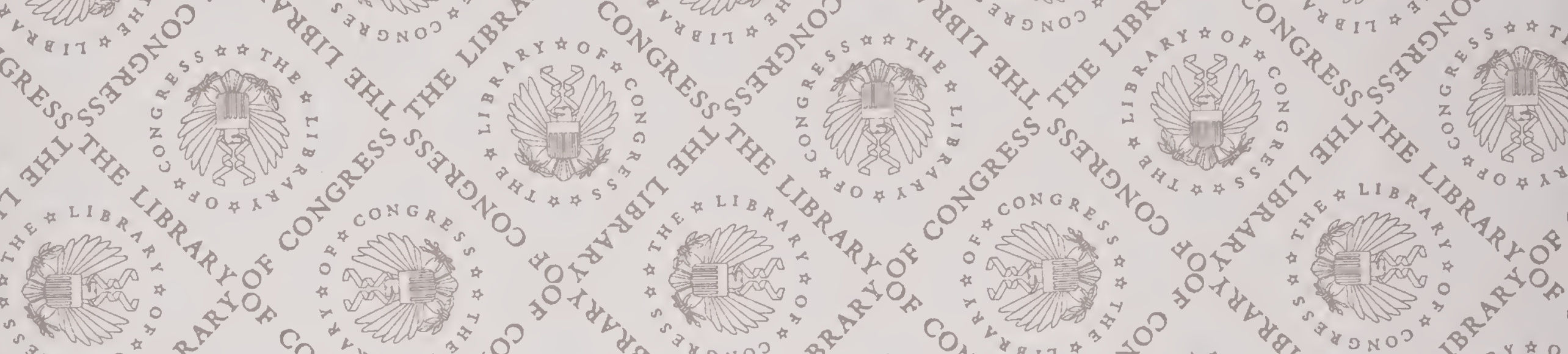

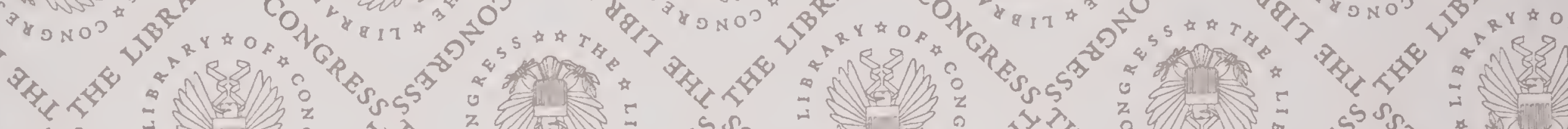

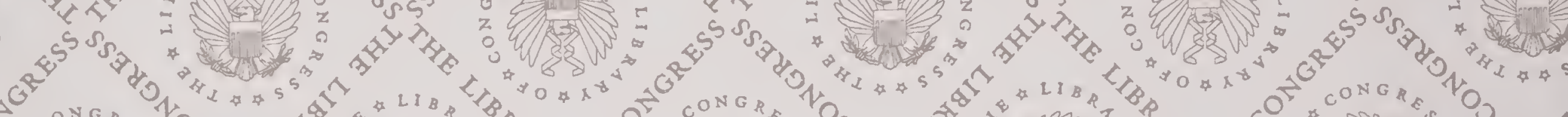

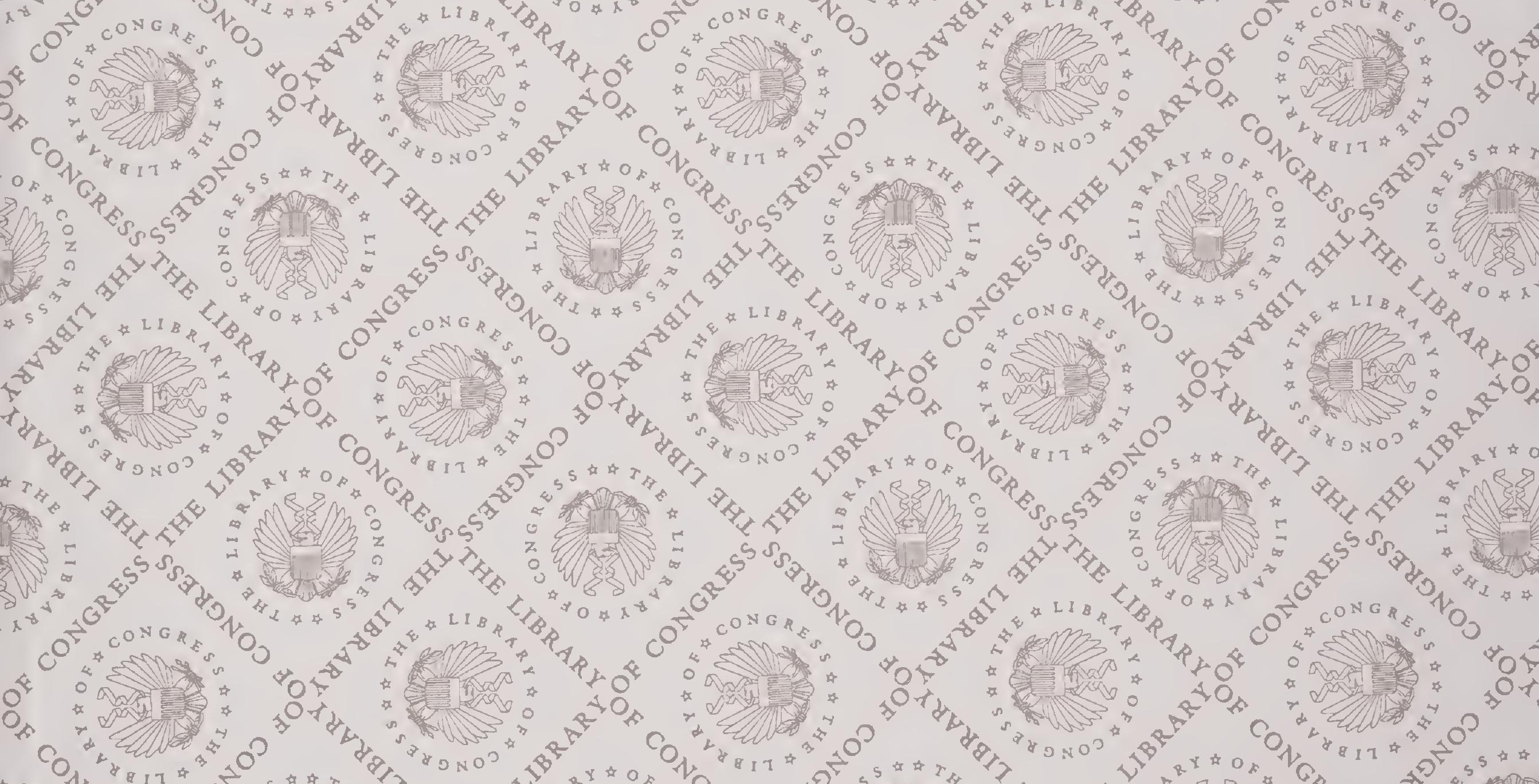

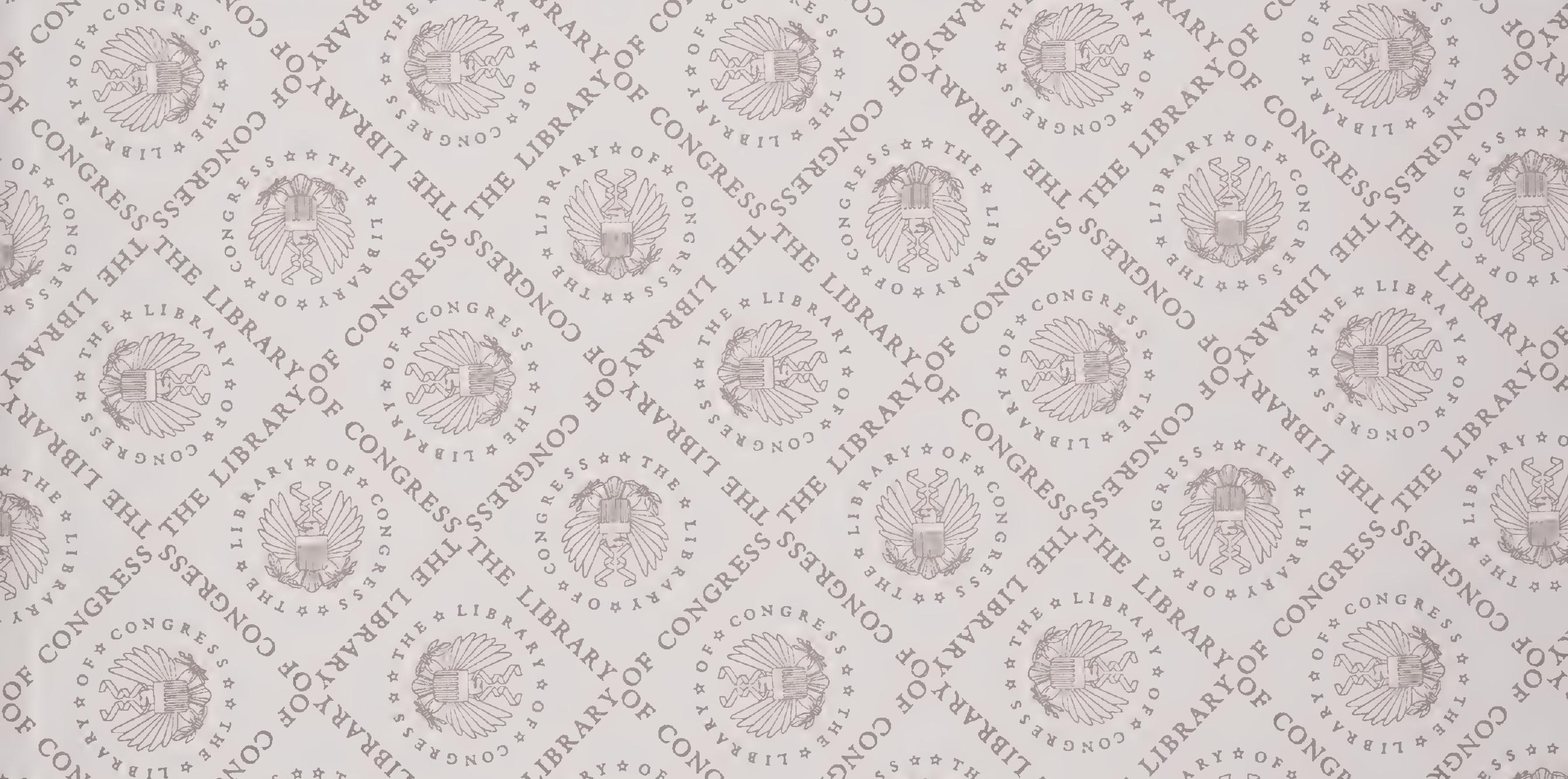

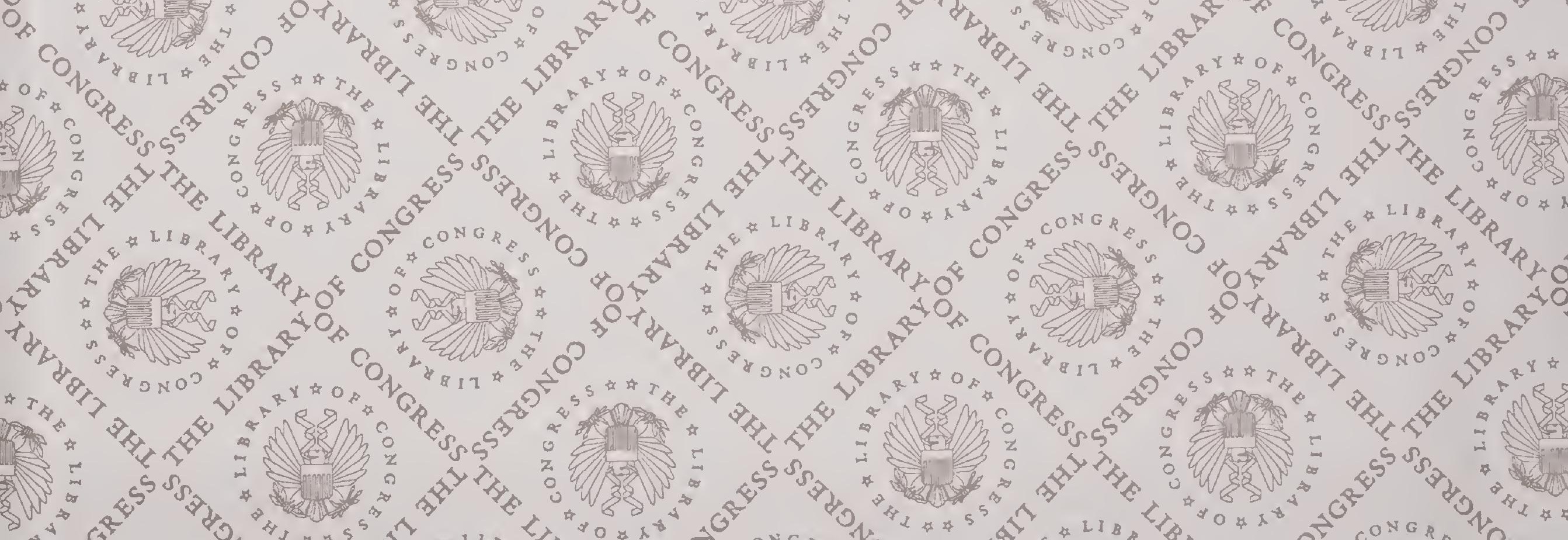


LIBRARY OF CONGRESS 